\author{
UNIVERSIDADE DE SÃO PAULO \\ FACULDADE DE ODONTOLOGIA DE RIBEIRÃO PRETO
}

\title{
AVALIAÇÃO DA REMODELAÇÃO ÓSSEA EM ALVÉOLOS DENTÁRIOS, APÓS A APLICAÇÃO DO LASER DE BAIXA POTÊNCIA.
}

LARISSA NOGUEIRA SOARES RIBEIRO

Ribeirão Preto 


\section{AVALIAÇÃO DA REMODELAÇÃO ÓSSEA EM ALVÉOLOS DENTÁRIOS, APÓS A APLICAÇÃO DO LASER DE BAIXA POTÊNCIA.}

Dissertação apresentada à Faculdade de Odontologia de Ribeirão Preto da Universidade de São Paulo, para a obtenção do Título de Mestre em Ciências.

Programa: Odontopediatria

Área de Concentração: Odontopediatria

Orientadora: Profa. Dra. Maria Bernadete Sasso Stuani

Ribeirão Preto 
AUTORIZO A REPRODUÇÃO E DIVULGAÇÃO TOTAL OU PARCIAL DESTE TRABALHO, POR QUALQUER MEIO CONVENCIONAL OU ELETRÔNICO, PARA FINS DE ESTUDO E PESQUISA, DESDE QUE CITADA A FONTE.

FICHA CATALOGRÁFICA

Ribeiro, Larissa Nogueira Soares

Avaliação da Remodelação Óssea em alvéolos dentários, após a aplicação do Laser de Baixa Potência.

Ribeiro, Larissa Nogueira Soares, Ribeirão Preto, 2013.

120 p.; il.; $30 \mathrm{~cm}$

Dissertação de Mestrado apresentada à Faculdade de Odontologia de Ribeirão Preto/USP - Área de concentração: Odontopediatria.

Orientadora: Stuani, Maria Bernadete Sasso

1. laser de baixa potência, 2. remodelação óssea, 3. TRAP, 4. RUNX-2, 5. Osso. 
FOLHA DE APROVAÇÃo

RIBEIRO, Larissa Nogueira Soares

Avaliação da Remodelação Óssea em alvéolos dentários, após a aplicação do Laser de Baixa Potência.

Dissertação apresentada à Faculdade de Odontologia de Ribeirão Preto da Universidade de São Paulo, para a obtenção do Título de Mestre em Ciências.

Área de Concentração: Odontopediatria

Aprovado em:

\section{Banca Examinadora}

Prof. Dr.

Instituição:

Julgamento: Assinatura:

Prof. Dr. Instituição:

Julgamento: Assinatura:

Prof. Dr. Instituição:

Julgamento: Assinatura: 


\section{DADOS CURRICULARES}

\section{LARISSA NOGUEIRA SOARES RIBEIRO}

Nascimento: $\quad 7$ de novembro de 1987- Uberaba- MG

Filiação:

Miriam Isabel Nogueira

Melânio Soares Ribeiro Neto

2007-2010

Curso de Graduação

Faculdade de Odontologia de Ribeirão Preto- Universidade de São Paulo- FORP/USP

2011-2012

Curso de Aperfeiçoamento no Atendimento Odontológico a Pacientes Especiais

Faculdade de Odontologia de Ribeirão Preto da Universidade de São Paulo

2011-2013

Curso de Especialização em Odontopediatria Associação Odontológica de Ribeirão Preto- AORP

2011-2013

Curso de Pós-Graduação (Mestrado) em Odontologia Área de Concentração: Odontopediatria

Faculdade de Odontologia de Ribeirão Preto da Universidade de São Paulo 


\section{DEDICATÓRIA}

A Deus, por ter me dado o privilégio da vida. Que me oferece todos os dias oportunidades mágicas e coloca sempre em meu caminho pessoas iluminadas para que minha caminhada se torne mais fácil.

"Pai, ensina-me a dizer somente palavras que abençoem,

Ensina-me a ouvir apenas a Verdade,

Clareia a minha visão para que meus olhos só vejam o bem,

Mostre-me caminhos para que meus pés trilhem a fé e a esperança,

Abençoe minhas mãos para que cada gesto seja de Amor e Cura.

Senhor, ensina-me, neste momento, a calar para que eu possa ouvir-Te".

(Parte da Oração de agradecimentos internos, Central Crisostelar de Lira)

Ao meu Anjo da Guarda, que esta sempre comigo, me protegendo e me iluminando!

A minha mãe, Miriam Isabel Nogueira, que lutou a vida toda para que seus filhos pudessem estudar e ter uma vida melhor. Que sempre me orientou e aconselhou da melhor maneira possível e foi essencial para que eu chegasse ate aqui. Obrigada pelo amor e pela dedicação incondicional, e por lutar ao meu lado pelos meus sonhos! Te amo!

Ao meu pai, Melânio Soares Ribeiro Neto, que me apoiou e me orientou nas minhas escolhas e me deu a oportunidade de chegar ate aqui. Obrigada por todo o amor e pelo seu apoio. Amo você! 
A toda a minha Família, principalmente meus avós, que sempre me apoiaram e me ajudaram, e principalmente a minha Madrinha, Vânia Elizabete Nogueira, que está sempre ao meu lado com todo seu amor, dedicação e carinho.

Ao meu irmão, Rodolfo Nogueira Soares Ribeiro, que foi sempre um exemplo pra mim e que também teve participação nas minhas conquistas!

Ao meu namorado, Felipe Caruso Soares, que surgiu na minha vida como um presente e que me faz feliz cada dia mais! Obrigada por me ajudar a superar os obstáculos e por compreender momentos de minha ausência para concluir essa dissertação. Te amo!

A todos os meus familiares e amigos que sempre torceram por mim! 


\section{AGRADECIMENTOS}

À Faculdade de Odontologia de Ribeirão Preto da Universidade de São Paulo, na pessoa do atual diretor, Prof. Dr. Valdemar Mallet da Rocha Barros, e da vicediretora, Profa. Dra. Léa Assed Bezerra da Silva.

À Coordenação do Curso de Pós-Graduação em Odontopediatria da Faculdade de Odontologia de Ribeirão Preto da Universidade de São Paulo, na pessoa da coordenadora, Profa. Dra. Léa Assed Bezerra da Silva e da vicecoordenadora Profa. Dra. Raquel Assed Bezerra Segato.

À minha orientadora, Profa. Dra. Maria Bernadete Sasso Stuani, por sempre estar presente nos experimentos e em todos os momentos que precisei, pela dedicação, pela paciência de me ensinar, pela amizade e por me ajudar sempre! Obrigada pela oportunidade de aprender com a senhora, não só os ensinamentos científicos mais principalmente os de vida!

Aos Professores do Departamento de Clínica Infantil, da Faculdade de Odontologia de Ribeirão Preto da Universidade de São Paulo, Profa. Dra. Aldevina Campos Freitas, Profa. Dra. Andiara de Rossi, Profa. Dra. Kranya Victória Díaz Serrano, Prof. Dr. Fábio Lourenço Romano, Prof. Dr. José Tarcísio Lima Ferreira, Profa. Dra. Léa Assed Bezerra da Silva, Profa. Dra Maria Conceição Pereira Saraiva, Profa. Dra. Maria Cristina Borsatto, Prof. Dr. Mário Roberto Leonardo, Profa. Dra. Mírian Aiko Nakame Matsumoto, Prof. Dr. Paulo Nelson Filho, Profa. Dra. Raquel Assed Bezerra da Silva, pelo incentivo, ensinamentos e colaboração durante minha formação acadêmica e científica. 
Profa. Dra. Alexandra Mussolino de Queiroz, por ser tão gentil e atenciosa, por todos os ensinamentos e paciência e por sua colaboração na minha formação.

À Profa. Dra. Mamie lyomasa Mizusaki e Prof. Dr. João Paulo Issa, por terem me acolhido em seu laboratório de pesquisa.

A todos os colegas do laboratório por toda ajuda e convivência sempre agradável.

À funcionária, Nilce de Oliveira Wolga, por toda a ajuda e paciência!

Ao Prof. Dr. Edilson Ervolino do departamento de histologia da UNESP, e à pós-graduanda, Bruna Gabriela dos Santos Kotake, pelo auxílio no desenvolvimento desta pesquisa.

Aos Pós-Graduandos em Odontopediatria da Faculdade de Odontologia de Ribeirão Preto da Universidade de São Paulo, Ana Caroline Fumes, Ana Zilda Nazar Bérgamo, Bárbara Jarreta, Cristina Bueno Brandão, Daniela Silva Barroso de Oliveira, Danielly Cunha Araújo Ferreira, Denise de Souza Matos, Daniele Lucca Longo, Driely Barreiros de Oliveira, Fernanda Regina Ribeiro Santos, Gabriela Cristina Sautin, Giselle de Ângelo Leite Carbonaro Guerreiro, Karina Grecca Pieroni, Késsia Suênia Fidélis de Mesquita, Katharina Morant Holanda de Oliveira, Letícia Andreotti Bignardi, Lidia Regina da Costa Hidalgo, Marcela Cristina Damião Andrucioli, Mariana Alencar Nemezio, Marília Rodrigues Moreira, Marina Fernandes de Sena, Marta Maria Martins Giamatei Contente, Maya Arnez, Priscilla Coutinho Romualdo, Rodrigo Valério, Silvana 
Aparecida Fernandes Polizeli, Talita Pereira Prates, Talitha de Siqueira Mellara, por todos os momentos compartilhados e pela convivência sempre tão agradável.

Às mais novas pós-graduandas em Odontopediatria, Carolina Maschietto Pucinelli, Francine Lorencetti da Silva, Juliana Arid, Maria Gabriela Flores Bracho, Mariana de Oliveira Daltoé, Marina Moscardini Vilela, Paula Regina Ávila Silvano, Sofia Sampaio Meireles de Souza e Sara Silva de Oliveira, pela oportunidade de conviver com vocês.

Às pós-graduandas, Elaine Machado Pingueiro Okada e Maya Fernanda Manfrin Arnez, por toda ajuda, paciência, auxilio na execução da parte experimental deste projeto e por todos os ensinamentos durante esses dois anos e meio. Muito Obrigada!

Às minhas queridas amigas de turma de mestrado, Bárbara Jarreta, Driely Barreiros de Oliveira e Silvana Aparecida Fernandes Polizeli, não tenho nem palavras para agradecer vocês! Vocês foram essenciais na minha vida, foram "presentes" que ganhei neste mestrado. Obrigada por todo o apoio, ajuda, risos e pela valiosa amizade de vocês! Meus anjinhos da guarda, quero sempre vocês por perto...

Ás minhas amigas, Ana Beatriz Silva Sousa, Andrea Sayuri Terada, Ana Flávia Maida, Larissa Gabrielle, Mariana D. Crivelenti, Mariana Silva e Souza, Nathália Giusti de Campos, Priscilla Coutinho Romualdo e a amiga e irmã, Paula Ferreira, que mesmo de longe me apoiaram durante esses anos. Vocês foram e são muito importantes na minha vida! Amo vocês! 
Ao meu primo, Maxwell Nogueira, pelo apoio e ajuda nas correções deste trabalho.

Ao aluno de Iniciação científica, Gabriel Barretto, por toda ajuda durante a execução da parte laboratorial desde projeto.

Aos funcionários do Departamento de Clínica Infantil e da Clínica de Pacientes Especiais da Faculdade de Odontologia de Ribeirão Preto da Universidade de São Paulo, Carolina Paes Torres Mantovani, Francisco Wanderlei Garcia de Paula e Silva, Micheli Cristina Leite Rovanholo, Fátima Aparecida Jacinto Daniel, Matheus Morelli Zanela, Filomena Leli Placciti, Marco Antonio dos Santos, Nilza Letícia Magalhães, Tatiana Goudromihos, pela ótima convivência.

Aos funcionários da Faculdade de Odontologia de Ribeirão Preto, Benedita Viana Rodrigues, Fátima Aparecida Rizoli e Renata Aparecida Fernandes, José Aparecido Neves do Nascimento, Vera do Nascimento Scandelai e Karina Dadalt Quaglio por todo carinho e atenção para com os alunos e pacientes e todo apoio nas atividades clínicas.

Aos funcionários do Biotério de Animais da Faculdade de Odontologia de Ribeirão Preto- FORP/USP, Antônio Sérgio Aparecido Mesca, Antônio Massaro e Aline Aparecida Ferraresi Tiballi pela disposição e ajuda durante os procedimentos experimentais e cuidados com os animais.

Aos funcionários da Seção de Pós-Graduação da Faculdade de Odontologia de Ribeirão Preto da Universidade de São Paulo, Isabel Cristina Galino Sola, Regiane Cristina Moi Sacilloto e Leandro Marin Silva, pela atenção e disposição. 
À Coordenação de Aperfeiçoamento de Pessoal de Nível Superior (CAPES) pela bolsa concedida.

Aos Professores da Banca, pela atenção dispensada na leitura desta dissertação.

A todos aqueles que não foram citados, mas contribuíram de alguma forma deste momento em minha vida. Muito obrigada! 


\section{RESUMO}

Ribeiro, LNS. Avaliação da Remodelação Óssea em alvéolos dentários, após a aplicação do Laser de Baixa Potência. 2013. 120f. Dissertação (Mestrado)- Faculdade de Odontologia de Ribeirão Preto, Universidade de São Paulo, Ribeirão Preto, 2013.

Introdução: A terapia com laser de baixa potência (LBP) vem sendo utilizada em Odontologia com diversos objetivos, em especial o de diminuir o tempo de cicatrização de feridas cirúrgicas. Objetivo: O objetivo do presente estudo in vivo foi avaliar qualitativamente e quantitativamente o efeito da irradiação com LBP no processo de remodelação óssea após a extração dentária em ratos jovens. Material e Método: Foram utilizados 60 ratos Wistar, distribuídos aleatoriamente nos seguintes grupos: Grupo Controle $(n=30)$ animais com extração dentária sem aplicação do LBP, e Grupo Experimental $(n=30)$ animais que tiveram extração dentária (Ext) e aplicação do LBP (Ext+LBP) nos três primeiros dias $\left(54 \mathrm{~J} / \mathrm{cm}^{2}\right.$ por dia). Os animais foram sacrificados nos períodos de 1, 2, 3, 5, 7 e 10 dias após o procedimento de extração dentária. Neste estudo foram analisados os efeitos da aplicação do laser sobre o reparo alveolar através de microscopia de luz, luz polarizada e imunomarcação. Para isso foram avaliados os seguintes parâmetros: 1) porcentagem de formação óssea no interior do alvéolo; 2) grau de processo inflamatório; 3) grau de amadurecimento do colágeno; 4) imunomarcação para TRAP e RUNX-2. Todos os resultados obtidos foram submetidos à análise estatística através do teste ANOVA e teste de Mann-Whitney $U(p<0.05)$. Resultados: Observou-se que os alvéolos do Grupo Experimental apresentaram processo de reparo mais evoluído quando comparados ao Grupo Controle, caracterizado pela organização mais rápida do coágulo sanguíneo, proliferação de fibroblastos nos restos do ligamento periodontal mais pronunciada, organização do colágeno e formação óssea mais precoce e mais intensa. Conclusão: A utilização do laser de baixa potência acelerou o processo de formação óssea durante as fases iniciais do experimento, embora nos períodos finais não houve diferença no processo de ossificação.

Palavras-chave: laser de baixa potência, osso, remodelação óssea, RUNX-2, TRAP. 


\section{ABSTRACT}

Ribeiro, LNS. Bone Remodeling Valuation in tooth alveolus, after Low Power Laser. 2013. 120f. Dissertation (Mastership) - School of Dentistry from University of São Paulo, in Ribeirão Preto - SP - Brazil, 2013.

Introduction: Low Power Laser ( $L P L)$ therapy has been used in Dentistry to achieve many objectives, particularly to decrease the healing period on wound healing. Objectives: The purpose of this in vivo study was to evaluate qualitatively and quantitatively the irradiation effect with LPL in the bone remodeling process after tooth extraction in young rats. Material and Method: 60 Wistar rats were used, randomly distributed in the following groups: Control Group $(n=30)$ animals with tooth extraction without LPL application, and Experimental Group $(n=30)$ animals with tooth extraction (Ext) and LPL application (Ext+LPL) on the three fist days (54 $\mathrm{J} / \mathrm{cm}^{2}$ per day). The animals were euthanized after the end periods of 1, 2, 3, 5, 7 and 10 days after the tooth extraction. This study looked into the effects of laser application on the alveolar repair through light microscopy, polarized light and immunostaining. After that, the following parameters were evaluated: 1) percentage of bone formation inside the dental alveolus; 2) degree of inflammatory process; 3 ) degree of collagen maturation; 4) immunostaining for TRAP and RUNX-2. All the results obtained were submitted to statistical analysis over the ANOVA and MannWhitney $(p<0.05)$ test. Results: It was observed that the alveolus from the Experimental Group presented an improved repair process when compared to the Control Group, characterized by faster blood clot organization, more apparent fibroblasts proliferation on the remnants of the periodontal ligament, earlier and more intense collagen organization and bone generation. Conclusion: The use of Low Power Laser accelerated the bone generation process during the experimental initial period, although there was no difference in the ossification process in the final periods.

Keywords: Low Power Laser therapy, bone, bone remodeling, RUNX-2, TRAP. 


\section{LISTA DE ILUSTRAÇÕES}

Figura 1: (A) Foto mostrando a extração do primeiro molar superior direito e (B) local da extração....35

Figura 2: Foto ilustrativa de um corte histológico onde é calculado a área do alvéolo (limite amarelo) e a área de osso neoformado (limites vermelhos) utilizando o ImageJ................................................50

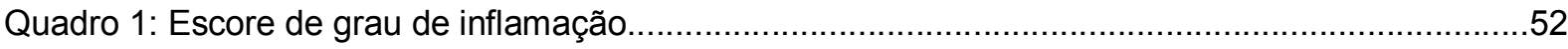

Quadro 2: Escore do grau de amadurecimento do colágeno (anisotropia)........................................52

Figura 3: Foto ilustrativa de corte histológico corado para TRAP e RUNX-2 ......................................54

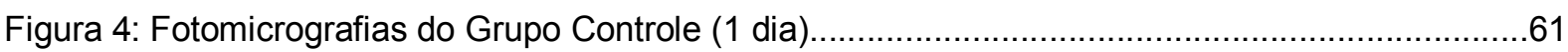

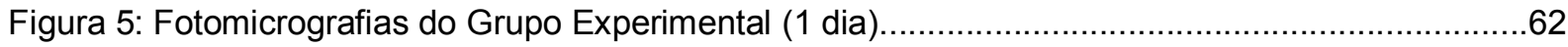

Figura 6: Fotomicrografias do Grupo Controle (2 dias).............................................................64

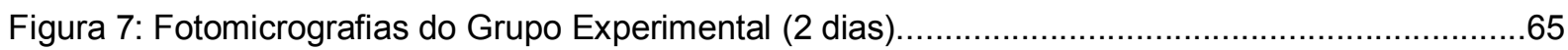

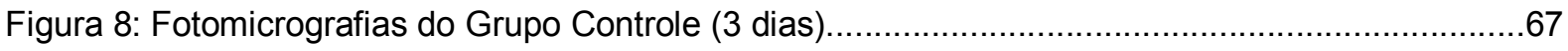

Figura 9: Fotomicrografias do Grupo Experimental (3 dias)........................................................68

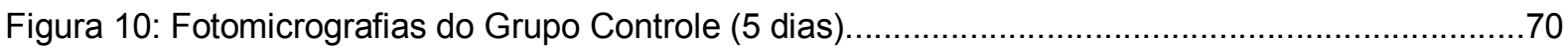

Figura 11: Fotomicrografias do Grupo Experimental (5 dias)..................................................... 71

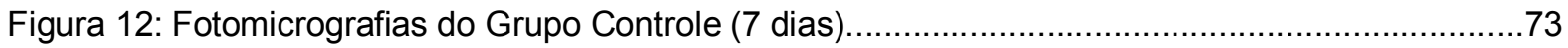

Figura 13: Fotomicrografias do Grupo Experimental (7 dias)........................................................

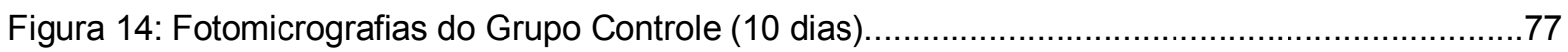

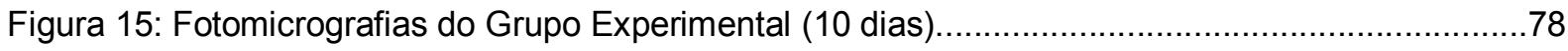

Figura 16: Expressão da percentagem média e desvio padrão da formação óssea no Grupo Controle

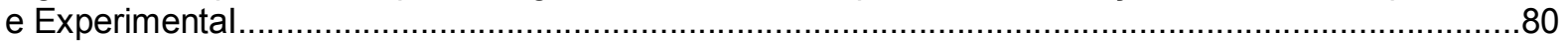

Quadro 3: Análise de variância (ANOVA) e teste de TUKEY dos resultados histomorfométricos, referentes à percentagem de trabéculas ósseas formadas entre o Grupo Controle e Laser.

Quadro 4: Escore individual de cada espécime e mediana de cada grupo para a intensidade do processo inflamatório em todos os períodos para o Grupo Controle e experimental..

Figura 17: Gráfico de barras ilustrativo da mediana do grau para a intensidade do processo inflamatório em todos os períodos para o Grupo Controle e Experimental.

Figura 18: Expressão da média e desvio padrão no número de perfis de células inflamatórias no

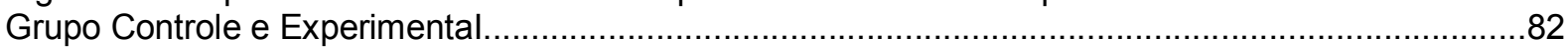

Quadro 5: Teste de Mann-Whitney para o evento grau de inflamação. .82

Quadro 6: Escore individual de cada espécime, da mediana de cada grupo, para a maturação do colágeno em todos os períodos para o Grupo Controle e experimental...... 
Figura 19: Gráfico de barras ilustrativo da mediana do grau de maturação de colágeno em todos os períodos para o Grupo Controle e Experimental......

Figura 20: Fotomicrografias por luz polarizada do Grupo Controle e Experimental mostrando a maturação do colágeno.

Figura 21: Expressão da média e desvio padrão no grau de amadurecimento do colágeno no Grupo Controle e Experimental.

Quadro 7: Teste de Mann-Whitney para o evento grau de amadurecimento de colágeno.

Figura 22 : Expressão da média e desvio padrão no número de perfis de células imunomarcadas para o TRAP no Grupo Controle e Experimental.

Figura 23: Expressão da média e desvio padrão no número de perfis de células imunomarcadas para o TRAP no Grupo Controle e Experimental.

Figura 24: Expressão da média e desvio padrão no número de perfis de células imunomarcadas para o RUNX-2 no Grupo Controle e Experimental.

Figura 25: Expressão da média e desvio padrão no número de perfis de células imunomarcadas para o RUNX-2 no Grupo Controle e Experimental. 


\section{LISTA DE ABREVIATURAS E SIGLAS}

\begin{tabular}{|c|c|}
\hline AsGaAl & Arsenieto de gálio-alumínio \\
\hline AsGa & Arsenieto de gálio \\
\hline AT & Área total \\
\hline AON & Area de osso neoformado \\
\hline CEEA & Comissão de Ética na Experimentação Animal \\
\hline COBEA & Colégio Brasileiro de Experimentação Animal \\
\hline EDTA & Etilenodiaminotetracetatodissódico \\
\hline FC & Fatores de crescimento \\
\hline FORP-USP & $\begin{array}{l}\text { Faculdade de Odontologia de Ribeirão Preto da Universidade de } \\
\text { São Paulo }\end{array}$ \\
\hline $\mathrm{H} / \mathrm{E}$ & Hematoxilina e eosina \\
\hline TM & Tricrômico de Masson \\
\hline PS & Picrus Sirus \\
\hline $\mathrm{n}_{\mathrm{c}}$ & Números de osteoclastos \\
\hline $\mathrm{n}_{\mathrm{b}}$ & Números de células precursoras de osteoblastos \\
\hline $\mathrm{Nm}$ & O número de células imunomarcadas por $\mu \mathrm{m}^{2}$ \\
\hline RANK & Receptor ativador do fator nuclear Kappa B \\
\hline RANK-L & Ligante do receptor ativador Kappa B \\
\hline $\mathrm{He}-\mathrm{Ne}$ & Hélio e neônio \\
\hline InGaAIP & Fosfato de índio gálio e alumínio \\
\hline ATP & Adenosina trifosfato \\
\hline GC & Grupo Controle \\
\hline GE & Grupo Experimental \\
\hline HLLT & High-level laser therapy \\
\hline HRP & Peroxidase da raiz forte \\
\hline M-CSF & Fator estimulador de colônia de macrófago \\
\hline Laser & $\begin{array}{l}\text { Light amplification by stimulated emission of radiation } \\
\text { (Amplificação da luz por emissão estimulada da radiação) }\end{array}$ \\
\hline LBP & Laser de baixa potência \\
\hline LLLT & Low-level laser therapy \\
\hline OCC & Osteocalcina \\
\hline OPG & Osteoprotegerina \\
\hline PBS & Solução tampão fosfato salino \\
\hline RUNX-2 & Fator de transcrição relacionado ao Runt-2 \\
\hline
\end{tabular}


TNF

HRP

TNFa

TRAP
Fator de necrose tumoral

Peroxidase da raiz forte

Fator de necrose tumoral- $\alpha$

Tartrate-resistant acid phosphatase (Fosfatase ácida tártaroresistente) 


\section{LISTA DE SíMBOLOS}

$\begin{array}{ll}\% & \text { Expressa um valor em percentual } \\ { }^{\circ} \mathrm{C} & \text { Graus centígrados (Celsius) } \\ \mathrm{g} & \text { Gramas } \\ \mathrm{J} & \text { Joules } \\ \mathrm{J} / \mathrm{cm}^{2} & \text { Joules por centímetro quadrado } \\ \mathrm{ml} & \text { Mililitro } \\ \mathrm{mg} / \mathrm{kg} & \text { Miligrama por quilograma } \\ \mathrm{mm} & \text { Milímetro } \\ \mathrm{mm}{ }^{2} & \text { Milímetro quadrado } \\ p & \text { Valor- } p \\ \mathrm{pH} & \text { Potencial hidrogeniônico }\end{array}$




\section{SUMÁRIO}

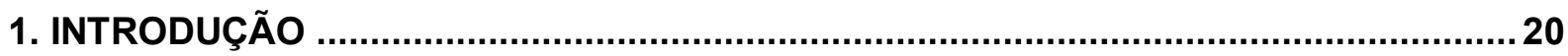

2. PROPOSIÇÃO

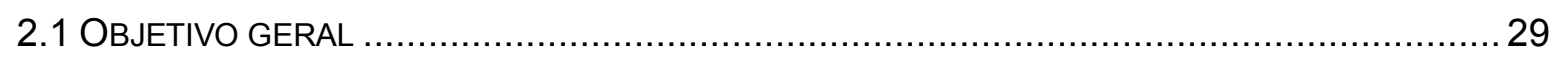

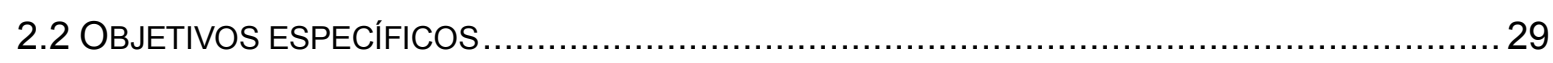

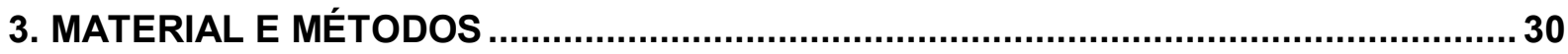

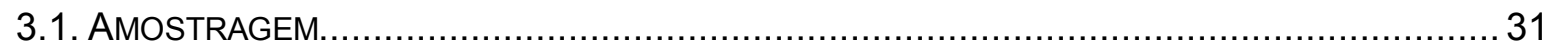

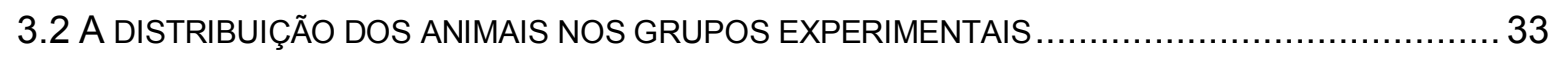

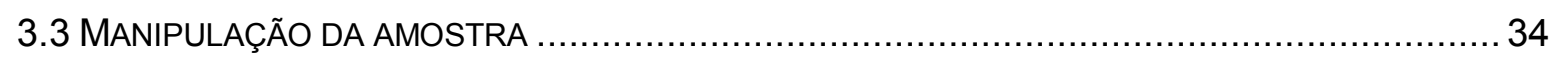

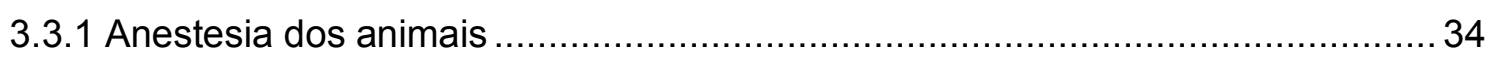

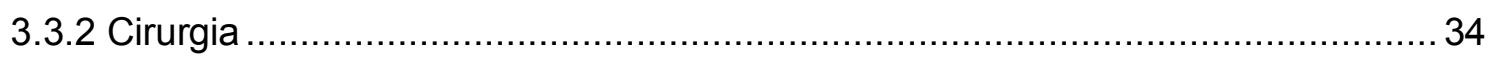

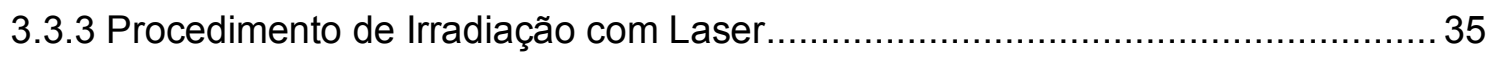

3.3.4 Eutanásia dos animais e obtenção das peças cirúrgicas .................................. 37

3.4 PREPARO DAS PEÇAS PARA EXAME HISTOLÓGICO E IMUNOISTOQUÍMICA .........................38

3.4.1 Coloração dos cortes para microscópio de luz ............................................... 41

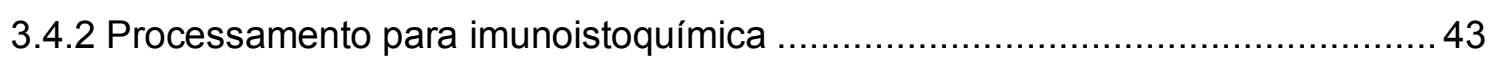

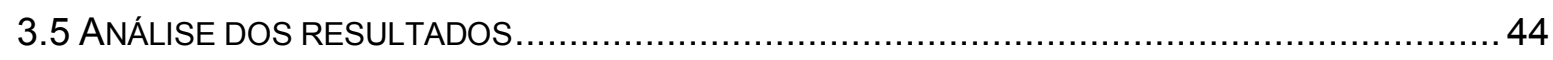

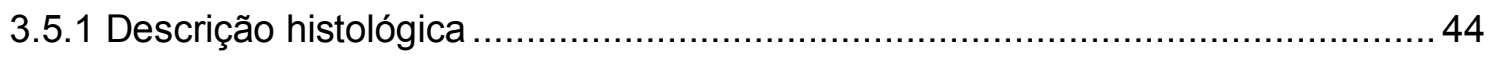

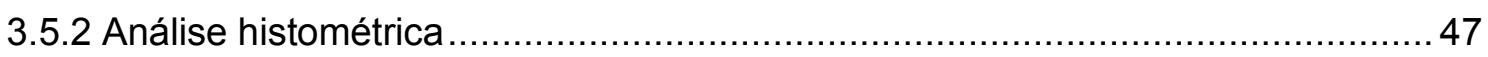

3.5.2.1 Análise histométrica em cortes histológicos ................................................. 48

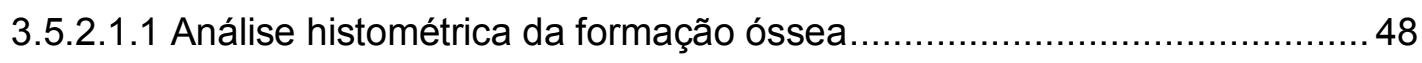

3.5.2.1.2 Análise histométrica do tecido inflamatório e do colágeno ......................51

3.5.2.2 Análise histológica das amostras submetidas à imunoperoxidase (Intensidade

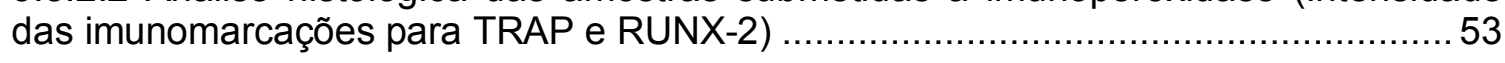

3.6 PRECISÃO DA METOdologIA (CALIBRAÇÃO dO EXAMINADOR) ……............................ 55

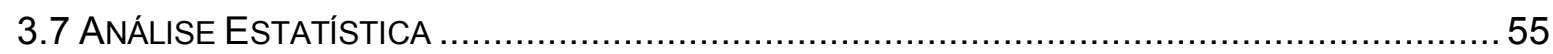

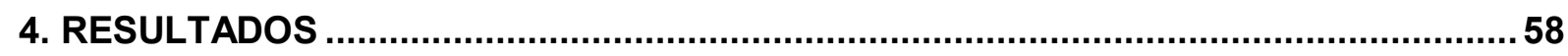

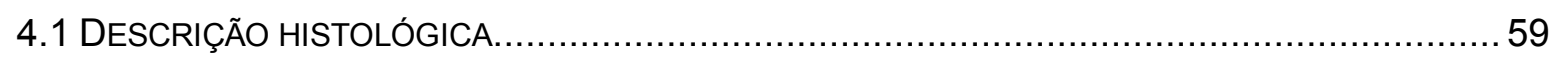

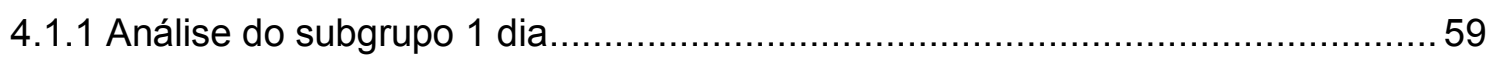

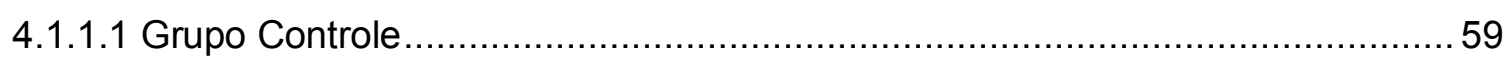

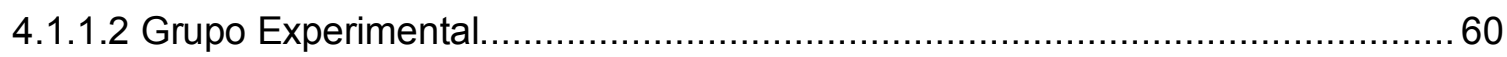

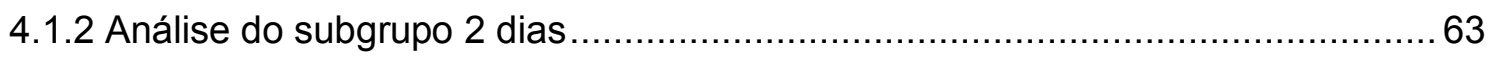

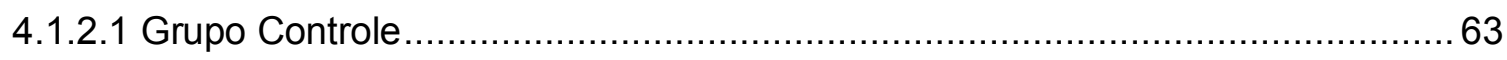

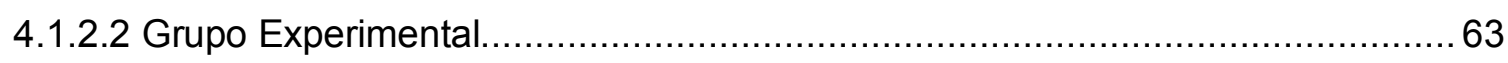

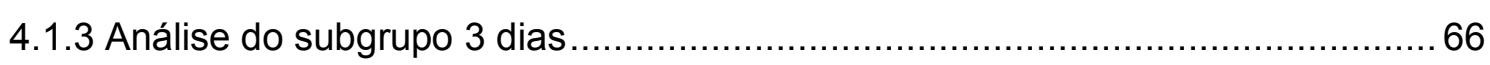




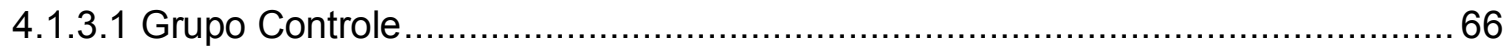

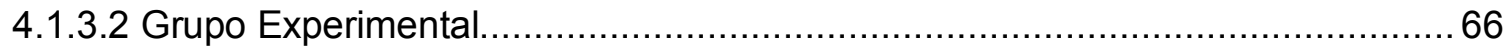

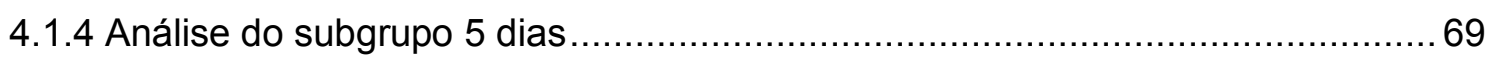

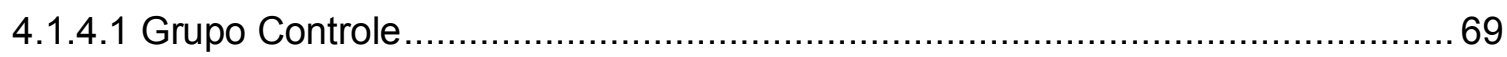

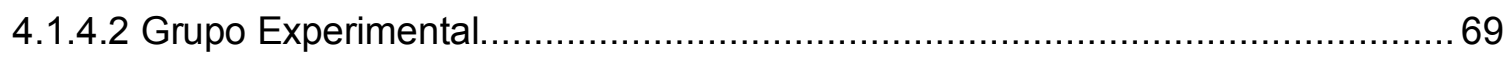

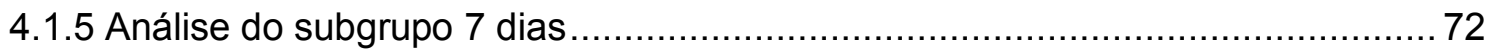

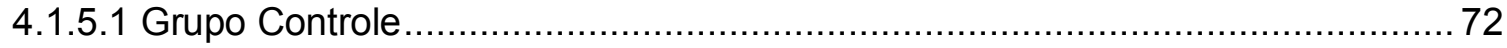

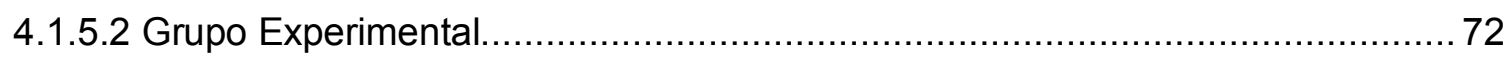

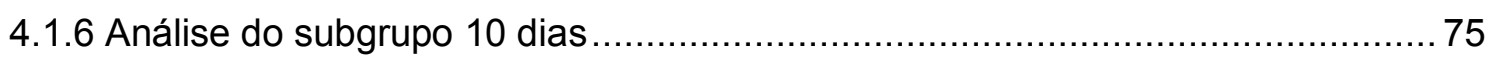

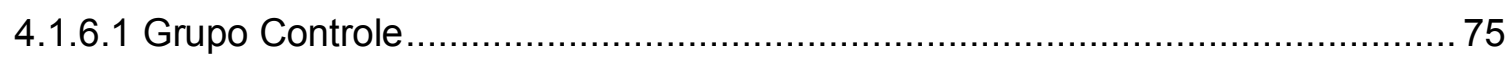

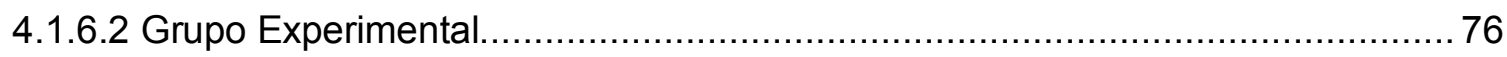

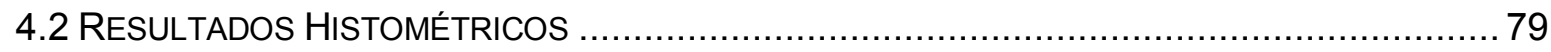

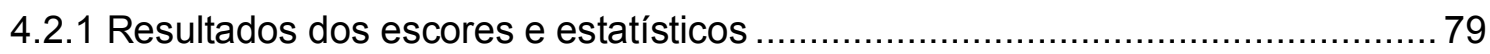

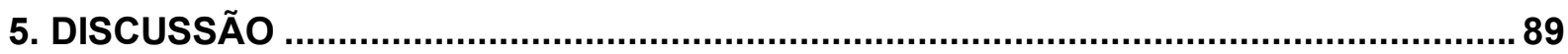

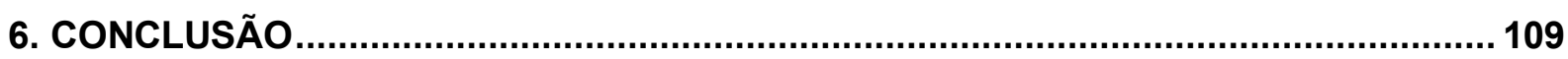

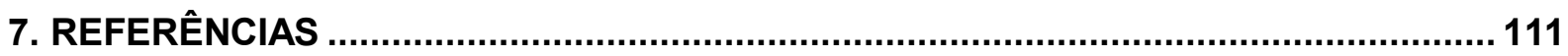




\section{Intradusãa}




\section{INTRODUÇÃO}

O processo de reparo de feridas após extração dentária tem sido analisado pelos pesquisadores por meio de estudos experimentais e clínicos, desde 1923 quando Euler (Euler, 1923) avaliou pela primeira vez esse fenômeno biológico. Os estudos utilizaram vários métodos como histológico, histoquímico e radiográfico que permitiram estabelecer os padrões normais deste evento (Amler, 1969; Okamoto e de Russo, 1973).

De acordo com Kawasaki e Shimizu, (2000) o processo de reparo alveolar em feridas de extração dental pode ser conceituado como o conjunto de eventos biológicos que ocorrem no interior do alvéolo, a partir da exodontia e que tem como objetivo fundamental preencher completamente o alvéolo dental com tecido ósseo. Morfologicamente podem ser consideradas quatro fases fundamentais na evolução do processo de reparo alveolar: a proliferação celular, o desenvolvimento do tecido conjuntivo, a maturação do tecido conjuntivo e a diferenciação óssea ou mineralização (Khadra, Ronold, Lyngstadaas, Ellingsen, Haanaes, 2004).

Logo após a exodontia, a cavidade da extração é preenchida por sangue e o coágulo que se forma a seguir, é gradativamente reabsorvido, à medida que é invadido por células endoteliais e fibroblastos que, originados de restos do ligamento periodontal, proliferam e migram para o seu interior. Forma-se então um tecido 
conjuntivo de reparo jovem, ricamente vascularizado e infiltrado por células inflamatórias linfoplasmocitárias (tecido de granulação). Na medida em que o tecido conjuntivo se torna progressivamente mais maduro pelo aumento da síntese de colágeno, diminui a quantidade de células inflamatórias e de vasos sanguíneos, e, começam a aparecer os osteoblastos (Brugnera e Zanin, 1998; Calixto, 2001).

Qualquer lesão óssea (fratura, defeito, fixação de implantes, extração dentária) ativa a regeneração óssea local pela liberação de fatores de crescimento (FC) e indutores. O osso é uma das fontes mais ricas em fatores de crescimento. $\mathrm{O}$ reparo em defeitos ósseos é um bom modelo para o estudo da regeneração óssea. A formação óssea inicia-se dois dias após a lesão, sendo totalmente preenchido por osso compacto após quatro semanas (Nicolau, 2001). O mecanismo de reparação óssea ocorre, em condições normais, inicialmente por um aumento da atividade osteoblástica, formando rapidamente tecido ósseo imaturo, matriz orgânica, seguida pelo depósito de sais de cálcio (Nicolau, 2001). Os osteoblastos originam-se de células mesenquimais indiferenciadas (células osteoprogenitoras) (Junqueira e Carneiro, 1999; Katchburian e Arana, 1999; Garant, 2003), e são responsáveis pela síntese e secreção de colágeno tipo I e de diversos componentes que constituem o tecido ósseo não mineralizado, ou osteóide, passível de mineralização posterior (Miller e Jee, 1992; Junqueira e Carneiro, 1999; Katchburian e Arana, 1999; Hall, 1994; Nicolau 2001; Garant, 2003;). Além disso, os osteoblastos participam do início do processo de mineralização dessa matriz óssea (Junqueira e Carneiro, 1999).

Durante a formação óssea, os osteoblastos são embebidos na matriz óssea e transformados em osteócitos. O mecanismo exato ainda não é conhecido. Sugerese que uma redução na secreção da matriz óssea pelas células mais velhas, combinado com uma secreção constante dos osteoblastos ativos vizinhos, pode 
levar o encapsulamento das células mais velhas dentro da matriz (Nefussi et al., 1991). Entretanto, eles não ficam isolados. Uma extensa rede de canalículos contendo prolongamentos citoplasmáticos dos osteócitos interconecta os canalículos, permitindo a difusão de nutrientes e de outras substâncias com as células vizinhas (Lian e Stein, 1992). Alguns osteoblastos permanecerão como células de reserva na superfície óssea, constituindo as chamadas células ósseas de revestimento (Aubin, 1998; Ten Cate, 2001; Garant, 2003).

Os osteoblastos regulam não somente a formação óssea, mas também a reabsorção óssea por meio da sinalização que controla a geração e atividade dos osteoclastos (RANK-L/OPG). Os osteoclastos são células gigantes multinucleadas, responsáveis pela reabsorção óssea (Robling et al., 2006). Ao contrário dos osteoblastos, originam-se das células do sistema monócitos/macrófagos (sistema hematopoiético). A osteoclastogênese começa com estímulo das células hematopoiéticas, que então se diferenciam em pré-osteoclastos. Os préosteoclastos fundem-se com outras células semelhantes para formar um osteoclasto imaduro multinuclear (Robey et al., 1993; Junqueira e Carneiro, 1999; Lerner, 2000; Garant, 2003). Em cortes histológicos, os osteoclastos são facilmente identificados por sua aparência multinuclear, expressão de receptores para calcitonina e coloração positiva para fosfatase ácida tártaro-resistente (TRAP) (Minkin, 1982; Fukushima et al., 1991).

Para cada passo da osteoclastogênese, fatores estimulantes específicos que regulam o desenvolvimento e função dos osteoclastos, precisam estar presentes, tais como: fator estimulador de colônia de macrófago (M-CSF), fator de diferenciação de osteoclastos (RANK-L), interleucinas, vitamina D3, fator de necrose tumoral- $\alpha$ (TNFa) e o contato com partículas de osso mineralizado contendo osteocalcina 
(Felix et al., 1994; Nishihara et al., 1994; Quinn et al., 1994; Tao e Minkin, 1994; Perkins e Kling, 1995; Suda et al., 1995; Owens et al., 1996; Suda et al., 1997; Quinn et al., 1998). O fator de diferenciação de osteoclasto (RANK-L) é um membro da superfamília do fator de necrose tumoral (TNF) e quando se ligam a seus receptores (RANK), levam a formação de osteoclastos (Nakagawa et al., 1998; Hofbauer et al., 2000), e consequentemente ao início da reabsorção óssea. A osteoprotegerina (OPG) é uma proteína circulante que inibe a formação (diferenciação) de osteoclastos através da união ao RANK-L expresso em osteoblastos prevenindo, assim, a interação estimulatória célula-célula com o préosteoclasto (Teitelbaum et al., 1995; Yasuda et al., 1998; Hofbauer et al., 2000).

Assim, como para os osteoclastos, para a formação de osteoblastos é essencial a presença de vários fatores específicos. Citocinas e fatores de crescimento, liberados da matriz óssea durante o processo de reabsorção, estimulam a formação e a ativação dos osteoblastos de forma que passem a sintetizar e a depositar uma quantidade equivalente de novo osso no local de reabsorção (Aubin, 1998; Ten Cate, 2001).

Portanto, a progressão da diferenciação de um osteoblasto requer tanto a ativação sequencial quanto a supressão de genes que codificam proteínas fenotípicas e regulatórias específicas (Stein et al., 1990; Stein et al., 1996). Sabe-se que todos os genes expressos em fibroblastos são também expressos pelo osteoblasto, mas existem dois fatores de transcrição que são especificamente encontrados somente em osteoblastos; são eles: um fator de transcrição chamado de RUNX-2 (CBFA-1) e a osteocalcina (OCC), uma proteína não-colágena da matriz óssea, ligante de cálcio. A expressão de RUNX-2 é restrita às células mesenquimais, destinadas a se tornarem condrócitos ou osteoblastos, precedendo 
assim a formação do osteoblasto. Depois, seguindo o processo de diferenciação, condrócitos não mais expressam o fator de transcrição RUNX-2, mas apenas osteoblastos apresentam essa propriedade (porém o nível de expressão é menor que o verificado de início nas células mesenquimais com destino a osteoblastos). Assim, o RUNX-2 é considerado o primeiro marcador específico da osteogênese (Ducy et al., 1997; Ducy et al., 2000). De acordo com alguns autores o RUNX-2 regula a expressão de osteocalcina (OCC) por osteoblastos já diferenciados e é necessário, mas não suficiente, para induzir a osteogênese (Lian e Stein, 1992).

Diversos efeitos bioestimulatórios da radiação laser de baixa potência (LBP) têm sido avaliados envolvendo o reparo ósseo, em particular, a aceleração da regeneração óssea (Kawasaki e Shimizu, 2000). Com o aparecimento do Raio Laser, em 1960, seus possíveis efeitos biológicos foram bem salientados na literatura (Maiman, 1960). Esses efeitos se processam de várias formas como, induzindo a atividade mitótica das células epiteliais (Kana et al., 1981), modificando a densidade capilar (Mester et al.,1978), estimulando a microcirculação local (Colls, 1984; Garcia, 1992) e, principalmente, aumentando a síntese do colágeno, tanto "in vitro" (Chomette et al., 1987 I), quanto "in vivo" (Chomette et al., 1987 II). Desde então, vários estudos (Kana et al., 1981; Takeda, 1988; Saito e Shimizu, 1997; Kawasaki e Shimizu, 2000; Freitas et al., 2001; Ueda e Shimizu, 2003) têm avaliado o seu emprego em diferentes tratamentos do complexo maxilo-facial. Avaliando esse mecanismo diversas pesquisas têm observado que o uso de laser de baixa potência pode exercer um efeito importante sobre o metabolismo do tecido ósseo.

De acordo com a classificação mais ampla os lasers são divididos em dois grandes grupos: os lasers não cirúrgicos, ou LLLT (Low-Level Laser Terapy), e os lasers cirúrgicos ou HLLT (High-Level Laser Terapy). Na odontologia os dois tipos de 
lasers são utilizados (Pinheiro, 1998). Os de alta potência têm ação de corte, vaporização, desnaturação de proteínas e coagulação de vasos, sendo indicado em cirurgias de tecidos moles bucais, fotopolimerização de resinas, clareamento dental e remoção de tecido cariado. O laser de baixa potência (LLLT) possui efeitos antiinflamatórios e analgésicos e modula a reparação tecidual, acelerando a cicatrização.

Pesquisas utilizando o laser terapêutico de baixa potência no osso mostraram que ele foi efetivo na modulação da inflamação, acelerando a proliferação celular, aumentando o número de osteócitos viáveis (Dortbudak et al., 2000; Ueda e Shimizu, 2003) e melhorando o processo de reparo ósseo (Trelles e Mayayo, 1987; Torricelli et al., 2001; Khadra, Kasem, Haanaes, Ellingsen e Lyngstadaas, 2004; Khadra, Ronold, Lyngstadaas, Ellingsen e Haanaes, 2004; Liu et al., 2007). Destes estudos, podemos supor que o laser de baixa intensidade pode acelerar a remodelação do tecido ósseo. A irradiação com laser após a extração dentária induz a aceleração da coagulação, diminuição do desconforto pós-operatório, e aceleração do reparo ósseo (Garcia et al.,2000).

Entretanto, um grande número de diferentes aparelhos de laser com diferentes comprimentos de ondas, incluindo o de hélio- neônio (HeNe 632.8 nm), o diôdo de arsenieto de gálio-alumínio (AsGaAl 805nm) e arsenieto de gálio (AsGa 904nm) têm sido usados com diferentes protocolos de tratamento (Khadra, Kasem, Haanaes, Ellingsen e Lyngstadaas, 2004; Khadra, Ronold, Lyngstadaas, Ellingsen e Haanaes, 2004; Liu et al., 2007; Nissan et al., 2006). O uso do laser diôdo AsGaAl, como no presente estudo, tem aumentado nos últimos 12 anos. Este tipo de laser apresenta um alto poder de penetração com comparação com outros tipos e oferece uma ferramenta clínica interessante na odontologia (Stuani, 2011). 
Embora o uso do laser de baixa potência na biomodulação do reparo ósseo ter crescido rapidamente e alguns estudos ter demonstrado resultados positivos no reparo do tecido ósseo (Trelles e Mayayo, 1987; Dortbudak et al., 2000) conclusões definitivas em relação aos efeitos deste laser no osso ainda são controversas, uma vez que relatos têm mostrado resultados conflitantes ou usado somente análises de métodos qualitativos (Takeda, 1988; Trelles e Mayayo, 1987). Poucos estudos tem tentado quantificar o efeito do LBP na formação óssea. E até o momento, não há estudos quantitativos que mostram a relação do LBP, na remodelação óssea e na síntese de RUNX-2, por osteócitos e osteoblastos, considerando que o mesmo é um importante fator de transcrição para a formação óssea.

Portanto, diante de diversos trabalhos da literatura científica que demonstram a viabilidade e as importantes descobertas do estudo relacionando o laser e a osteogênese, é de grande relevância associar e somar estes conhecimentos à extração dental e a biologia molecular e celular, visto que esta nova abordagem de estudo e avaliação é inicialmente inovadora. 
Q. Proposisãa 


\section{PROPOSIÇÃo}

\subsection{Objetivo geral}

O objetivo do presente estudo é avaliar in vivo a influência da aplicação do laser de baixa potência sobre o processo de remodelação óssea após a extração dentária, por meio de análise miscroscópica descritiva e imunoistoquímica

\subsection{Objetivos específicos}

1. Avaliar a influência do laser de baixa potência na remodelação óssea após a extração dentária através da análise descritiva dos eventos histológicos.

2. Quantificar o número de perfis de células inflamatórias, grau de amadurecimento do colágeno e números de trabéculas ósseas formadas durante o experimento.

3. Avaliar e quantificar a diferenciação osteoclástica e osteoblástica pela atividade da expressão de proteína TRAP e RUNX-2 no tecido ósseo durante a remodelação em ratos e verificar se há diferença entre os animais que foram irradiados com LBP e os não irradiados. 


\section{Material Mêtodos}




\section{MATERIAL E MÉTODOS}

\subsection{Amostragem}

Os procedimentos desta pesquisa obedeceram às recomendações éticas e legais especificadas para experimentação animal do Manual aprovado pelo Colégio Brasileiro de Experimentação Animal - COBEA 1991 e às recomendações legais conforme Lei № 6.638, de 08/05/1979, publicada no Diário Oficial da União, sendo aprovado pela Comissão de Ética na Experimentação Animal (CEEA) da Universidade de São Paulo - Faculdade de Odontologia do Campus de Ribeirão Preto (FORP-USP), sob protocolo no 09.1.1449.53.2.

A presente pesquisa utilizou 60 ratos adultos jovens, machos, saudáveis da linhagem wistar (Rattus norvegicus, albinus, Wistar) com 90 dias de idade, pesando em média 150 gramas. Os animais foram adquiridos no biotério central da Universidade de São Paulo - campus Ribeirão Preto, onde foram criados para fins de pesquisa e ensino, e transferidos para o Biotério da Faculdade de Odontologia da Universidade de São Paulo-campus Ribeirão Preto (FORP-USP), onde foram mantidos por 7 dias para adaptação. Animais machos foram utilizados para eliminar qualquer variabilidade hormonal devido ao ciclo reprodutivo feminino.

Durante o período experimental os animais permaneceram em gaiolas plásticas apropriadas específicas para esse fim, com locais apropriados para a 
colocação de água e ração, forradas com raspas de madeira (maravalha de pinus), contendo cada uma um número máximo de cinco animais. A maravalha teve a finalidade de absorver a urina dos animais e a água derramada no seu interior, mantendo o fundo da gaiola-viveiro, sempre seco e, foi totalmente substituída diariamente, fornecendo assim condições apropriadas de higiene necessárias ao bem-estar e saúde dos animais.

Durante a realização do experimento os animais foram mantidos no biotério de experimentação animal da FORP-USP, alimentados com dieta padrão constituída por ração moída (Labina-Purina) e água ad libitum, sendo assistidos por dois tratadores de animais. Foi efetuada a troca diária da ração com a finalidade de evitar formação e proliferação de fungos, por exposição prolongada do alimento ao meio ambiente. Água mineral foi fornecida através de dispensadores apropriados, adaptados à gaiola-viveiro, com bico de aço inoxidável, com capacidade de $500 \mathrm{ml}$, para garantir suprimento constante de água aos animais.

O uso de substâncias desinfetantes foi evitado durante a limpeza das gaiolas, para não causar qualquer interferência no experimento. O fotoperíodo foi controlado com intervalos de dia-noite de 12 horas, para evitar alterações no ciclo metabólico e a temperatura da sala do biotério oscilou entre 21 e $23^{\circ} \mathrm{C}$, ideal para o crescimento e desenvolvimento dos animais, sendo o local mantido constantemente arejado e limpo. 


\subsection{A distribuição dos animais nos grupos experimentais}

Os animais foram distribuídos aleatoriamente em dois grupos distintos: Controle e Experimental. Cada grupo foi subdividido em seis sub-grupos de acordo com o tempo de sacrifício após a extração dentária.

Grupo I (controle) $(n=30)$ - Composto de seis subgrupos (animais sacrificados 1, 2, 3, 5, 7 e 10 dias após a extração dentária) constituídos por cinco animais em cada subgrupo, onde foi realizado apenas a exodontia do primeiro molar superior direito. O animal controle foi utilizado para caracterizar o reparo ósseo alveolar após exodontia, servindo como parâmetro para comparação com os animais experimentais. A amostra foi destinada para análise histológica e imunoistoquímica.

Grupo II (experimental) $(n=30)$ - Composto de seis subgrupos (animais sacrificados 1, 2, 3, 5, 7 e 10 dias após a extração dentária) constituídos por cinco animais em cada subgrupo, onde foi realizado a exodontia do primeiro molar superior direito e irradiação com laser de baixa potência (LBP) utilizando o laser de AsGaAl por 3 dias consecutivos $\left(54 \mathrm{~J} / \mathrm{cm}^{2}\right.$ por dia). A amostra foi destinada para análise histológica e imunoistoquímica. 


\subsection{Manipulação da amostra}

\subsubsection{Anestesia dos animais}

Todos os procedimentos nos animais foram realizados sob anestesia. Para que as cirurgias de extração dentária fossem realizadas, os animais foram sedados com solução de Cloridrato de Ketamina (anestésico Ketamina Agener ${ }^{\circledR}$ ) em dosagem de $0,07 \mathrm{ml}$ para cada $100 \mathrm{~g}$ peso corporal, para a obtenção do efeito anestésico associado com a solução de Cloridrato de Xilazina (Dopaser ${ }^{\circledR}$, Laboratório Calier do Brasil. Ltda, Osasco, SP, Brasil) na dosagem de 0,03ml para cada $100 \mathrm{~g}$ de peso corporal, para promover um relaxamento muscular, administrados por via intramuscular, utilizando seringas descartáveis (Becton Dickson- Indústrias Cirúrgicas LTDA).

Para a introdução da agulha propriamente dita, o animal foi imobilizado em posição de decúbito dorsal, com o operador auxiliar segurando o dorso do animal mantendo as pernas traseiras distendidas lateralmente, onde introduziu a agulha hipodérmica descartável calibre $20 \mathrm{~mm} \times 0,8 \mathrm{~mm}$ (Ibrasgamma), acoplada a seringa plástica de 3ml (Becton Dickson - Indústrias Cirúrgicas LTDA), no músculo vasto lateral, com uma angulação de penetração de $45^{\circ}$ em relação ao longo eixo horizontal da perna esquerda do animal.

\subsubsection{Cirurgia}

Todas as cirurgias foram realizadas de acordo com as normas para a prática didático-científica da vivissecção de animais (lei 6638/08 de maio de 1979) e com os 
princípios éticos na experimentação animal sob condições de assepsia e sob anestesia.

Após sedados, os animais foram colocados em uma mesa operatória apropriada em decúbito dorsal e com auxílio de 2 abridores de boca confeccionados manualmente, foi possível visulizar melhor o campo operatório. Para a realização da exodontia do primeiro molar superior direito, foi utilizado o extrator de tártaro $\mathrm{N}^{0} 1$ (Duflex). Para tal procedimento, a ponta ativa desse instrumento foi inserida na região cervical do primeiro molar superior entre as raízes, e com movimento de luxação e extrusão o dente foi extraído. Após a extração dentária foi feita irrigação com soro fisiológico e hemostasia com auxílio de pelotas de algodão estéril (Cremer). Todos os procedimentos operatórios foram realizados na sala de Cirurgia Experimental do Biotério da FORP-USP sempre com os mesmos operadores.

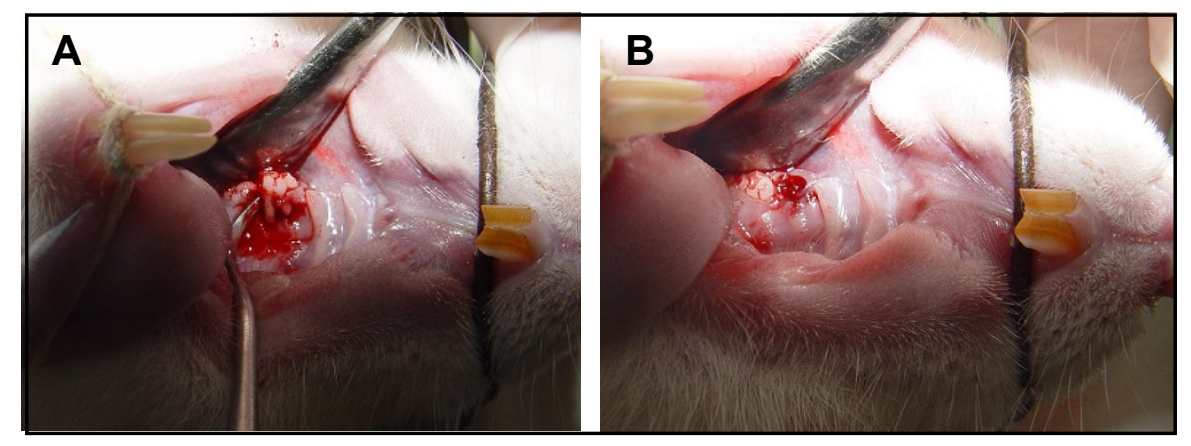

Figura 1: (A) Foto mostrando a extração do primeiro molar superior direito e (B) local da extração.

\subsubsection{Procedimento de Irradiação com Laser}

Nos animais do Grupo Experimental após a exodontia, o alvéolo recebeu aplicação direta e diária, por três dias consecutivos, de radiação laser terapêutico semicondutor de Arseneto de Gálio e Alumínio (GaAlAs) (Photon Laser DMC ${ }^{\circledR}$ - São Carlos - SP) com as seguintes características: 
- Meio ativo: Diodo de Arseneto de Gálio e Alumínio (AsGaAl);

- Comprimento de onda: 830nm de comprimento de onda (invisível e estando na faixa do infravermelho próximo),

- Potência de saída: 30mW (0,003W)

- Modo de emissão: modo contínuo;

- Modo de aplicação: contato pontual;

- Área de aplicação do Laser: A irradiação do laser foi realizada com a ponteira direcionada diretamente sobre o alvéolo em um ponto de aplicação (oclusal);

- Número de aplicação: aplicação única por 3 dias consecutivos;

- Diâmetro do feixe da ponteira: $6 \mathrm{~mm}$

- Área do Spot: corresponde a 0,00785 $\mathrm{cm}^{2}$ (área de irradiação)

- Fluência (Densidade de Energia pontual): $54 \mathrm{~J} / \mathrm{cm}^{2}$;

- Energia Total (X3 dias): $162 \mathrm{~J} / \mathrm{cm}^{2}$;

- Tempo de exposição pontual: 42 segundos;

- Tempo de exposição total: 126 segundos (3 dias consecutivos);

No caso do feixe de laser, a grandeza é a energia luminosa (medida em Joules) e a área é aquela abrangida pelo ângulo sólido formado pelo feixe sobre à superfície de aplicação (medida em $\mathrm{cm}^{2}$ ), que nesse aparelho de aplicação pontual, é fixa $\left(0,00785 \mathrm{~mm}^{2}\right)$. Essa dosagem $\left(\mathrm{J} / \mathrm{cm}^{2}\right)$ foi aplicada calculando-se o tempo (s) 
necessário numa determinada potência $(\mathrm{mW})$ de $30 \mathrm{~mW}(0,003 \mathrm{~W})$, onde: $\mathrm{D}=\mathrm{PxT} / \mathrm{A}$. $A$ ponta do laser é composta por uma fibra óptica $6 \mathrm{~mm}$ de diâmetro cuja área de irradiação corresponde a $0,00785 \mathrm{~mm}^{2}$, e a irradiação foi aplicada sob anestesia, colocando a extremidade da ponta da fibra óptica em contato com a mucosa palatal no local da extração dentária.

\subsubsection{Eutanásia dos animais e obtenção das peças cirúrgicas}

Os animais foram sacrificados a 1, 2, 3, 5, 7 e 10 dias após o ato cirúrgico, com sobre dose de anestésico (Ketamina e Xilazina) via intramuscular e perfundidos por via intracardíaca utilizando bomba perfusora Masterflex LS (Cole-Parmer Instrumet Company, Vermon Hills, IL, USA). Para isso, foi feito acesso na cavidade torácica, para posicionar, por via intracardíaca, através do ventrículo esquerdo, uma cânula de infusão, na aorta ascendente. Realizou-se a injeção intraventricular de heparina $(0,1 \mathrm{ml} / 5.000 \mathrm{U} . \mathrm{I} / \mathrm{ml})$ e após 10 segundos, realizou-se a perfusão via aorta, com $200 \mathrm{ml}$ de tampão fosfato salino a $10 \%$, $\mathrm{pH} 7,4$ (PBS) a $38^{\circ} \mathrm{C}$ seguida de solução fixadora $(400 \mathrm{ml})$ de paraformaldeído (Sigma Chemical Co., St. Louis, MO, USA) a 4\% em tampão fosfato de sódio (Sigma Chemical Co.,St. Louis, MO, USA) a $0,1 \mathrm{M}, \mathrm{pH} 7,4$ a $4^{\circ} \mathrm{C}$. Durante esse procedimento, os animais foram mantidos com a boca em abertura máxima, para facilitar a posterior remoção da maxila, objeto de interesse do presente estudo. Após a perfusão, as cabeças e as maxilas foram removidas. A hemi-maxila direita contendo o alvéolo em reparação foi separada da esquerda ao longo do plano sagital, na região da sutura palatina mediana com emprego de lâmina de bisturi n¹5 (Feather) tangenciando a sutura intermaxilar. Um corte com tesoura reta na porção distal do $3^{\circ}$ molar possibilitou a obtenção da maxila 
direita contendo a região da exodontia. As peças anatômicas apresentavam como limite posterior, o terceiro molar permanente superior, sendo que o limite anterior dez milímetros da região do primeiro molar superior. Durante a dissecção foi tomado o cuidado de não atingir a gengiva livre e a gengiva inserida. Em seguida as peças foram identificadas e pós-fixadas na mesma solução fixadora, em volume igual a vinte vezes o tamanho da peça, por 48 horas para completar a fixação.

\subsection{Preparo das peças para exame histológico e imunoistoquímica}

O preparo das peças para a microscopia ótica foi realizado no Departamento de Morfologia da Faculdade de Odontologia de Ribeirão Preto (FORP-USP). Após o término da fixação, os espécimes foram lavados em água corrente por 24 horas e, colocados em solução desmineralizadora de etileno-diamino-tetracetato-dissódico a $10 \%, 0,25 \mathrm{M}$ e pH=7,0 (EDTA - Merk), sob agitação constante à temperatura de 2 a $8^{\circ} \mathrm{C}$, por um período de 40 dias, com trocas por nova solução a cada 7 dias.

Durante a descalcificação, as peças foram armazenadas individualmente, em frascos esterilizados, contendo quantidade de solução descalcificada equivalente a 20 vezes o seu volume. Esse procedimento visa assegurar a preservação da matriz orgânica durante o processo de descalcificação. Depois de submetidos à desmineralização, todos os espécimes foram imersos em sulfato de sódio a $5 \%$ por 24 horas à temperatura ambiente, com a finalidade de neutralizar a ação da solução descalcificadora nas mesmas.

Em seguida, foi realizada desidratação rigorosa, em banhos sucessivos, de álcoois percentualmente aumentados em concentração $70 \%, 80 \%, 90 \%$ e $100 \%$ 
(Merck KGaA, Darmstadt, Alemanha), sucessivamente, por 60 minutos em cada concentração, na temperatura ambiente, com a finalidade de evitar trocas osmóticas bruscas, o que pode causar alterações nas estruturas. Concluída a desidratação, as peças foram diafanizadas através de três banhos de Xilol (Merk KGaA, Darmstadt, Alemanha), que é miscível tanto com álcool como com parafina, removendo todo o álcool e dando ao tecido condições de ser impregnado pela parafina. O tempo de imersão em cada uma (soluções de Xilol I, II e III), dependeu da evolução da diafanização, ficando ao redor de 40 minutos em cada solução.

Após o xilol ter substituído todo o álcool nas peças (diafanização), estas foram submetidas à parafinização lenta, promovida por seguidos banhos de xilol-parafina, nas proporções de $2: 1,2: 2$, e parafina pura de baixa temperatura de fusão $\left(56-58^{\circ} \mathrm{C}\right.$, Reagen), sendo que as peças ficaram imersas uma hora em cada banho. Durante este procedimento as peças foram mantidas numa estufa de temperatura constante regulada para $58^{\circ} \mathrm{C}$, até que o xilol fosse completamente substituído pela parafina fundida (Reagen). Tão logo a infiltração se completou, as peças foram posicionadas no centro de formas de alumínio com dimensões aproximadas de $30 \mathrm{~mm}$ de extensão por $15 \mathrm{~mm}$ de largura e profundidade a qual foi preenchida com parafina fundida de baixa temperatura de fusão $\left(56-58^{\circ} \mathrm{C}\right.$, Reagen). Antes da solidificação, cada peça foi posicionada bem no centro da forma de alumínio com parafina, com o auxílio de uma pinça clínica (Duflex) aquecida, de tal modo que a superfície oclusal dos molares ficasse paralela ao sentido dos cortes desejados. Os blocos de parafina solidificados foram identificados e colocados em água gelada e, em seguida, no refrigerador, para evitar sua cristalização. Em seguida esses blocos foram removidos das formas de alumínio, reduzidos com navalhas apropriada, até permanecer $5 \mathrm{~mm}$ de parafina de cada lado da peça de interesse e alcançar paralelismo ideal para serem seccionados 
no micrótomo rotativo de precisão (Spencer, modelo 820).

Secções transversais semi-seriadas com $5 \mu \mathrm{m}$ de espessura foram obtidas no sentido oclusal a cada $100 \mu \mathrm{m}$ por toda a extensão da peça. As fitas foram levadas ao cristalizador (Roberts Haw), onde foram distendidas e montadas em lâminas silanizadas para microscopia (Objektträger - Knittel Gläser), sendo distribuídas de maneira intercalada para as análises histológicas e imunoistoquímicas. Em cada lâmina foram colocados três cortes histológicos. A montagem posterior das lâminas foi feita com lamínulas de vidro em "entellan" (MERCK KgaA, Germany), para o exame microscópico de rotina. Posteriormente, essas lâminas com os cortes em posição foram mantidas em estufa, em posição vertical, pôr 24 horas, a $40^{\circ} \mathrm{C}$, para que a umidade evaporasse e para favorecer a aderência do material à lâmina. Durante este procedimento algodão embebido em formol, cujos vapores insolubilizam a gelatina e previnem a poluição microbiana, foi colocado na estufa junto com as lâminas para evitar a contaminação dos cortes por bactérias.

Os cortes semi-seriados obtidos, com $5 \mu \mathrm{m}$ de espessura, foram divididos em dois grupos, sendo que o primeiro grupo foi corado pela técnica da Hematoxilina e Eosina (H/E) para a análise morfológica, Tricrômico de Masson (TM) a fim de evidenciar a neoformação óssea e o colágeno existente no tecido conjuntivo mineralizado e não mineralizado e em Picrus Sirus (PS) para análise do grau de amadurecimento do colágeno por polarização e a outra parte submetida às reações imunoistoquímicas para análise específica contra antígeno específico (TRAP e RUNX-2). 


\subsubsection{Coloração dos cortes para microscópio de luz}

Para que o corte pudesse ser submetido à coloração, foi feita a desparafinização das lâminas. Para isso procedeu-se primeiro à eliminação da parafina dos cortes pelo xilol, mergulhando as lâminas em soluções de xilol I, II e III, com duração de 10 minutos em cada solução. Assim que foi constatada a eliminação da parafina dos cortes, foi iniciado o processo de hidratação, quando o xilol foi removido com banhos de álcool absoluto I, II e III, (Reagen) e, em seguida álcool 95\%, por 3 minutos em cada solução, até chegar à água destilada. Esse procedimento tem a finalidade de evitar fenômenos osmóticos bruscos, os quais produzem retrações e deslocamento do material da lâmina. Os cortes histológicos foram montados em série e corados com hematoxilina e eosina, tricrômico de Masson e Picrus sirus.

Para a coloração por Hematoxilina e eosina, os cortes hidratados foram submetidos à coloração pôr hematoxilina (Merck) por 3 minutos. Em seguida, realizou-se a lavagem das lâminas em água corrente até assumirem tom azulado, sendo então, mergulhadas rapidamente em solução de álcool acetificado (solução de ácido acético glacial diluído em álcool 95\%). Nova lavagem foi realizada em água corrente por 2 a 5 minutos e álcool a 95\%. A eosina foi utilizada (Merck) pôr 2,5 minutos, dando aos tecidos uma cor rosada. A seguir foi realizada nova desidratação através de três banhos de álcool absoluto I, II e III por 3 minutos cada, e três banhos de xilol (Merk) I, II e III também por 3 minutos cada. Finalmente, as lâminas foram cobertas com lamínulas montadas com Entellan (Merck).

Para a coloração por Tricrômico de Masson, os cortes hidratados foram submetidos à coloração pôr Alumen de ferro a $5 \%$, dentro da estufa $\left(38^{\circ} \mathrm{C}\right.$ a $\left.40^{\circ} \mathrm{C}\right)$ 
por 17 min. Em seguida, realizou-se a lavagem das lâminas em água corrente, seguida por água destilada. Os cortes foram então submetidos à coloração pôr Hematoxilina de Regaud dentro da estufa $\left(38^{\circ} \mathrm{C}\right.$ a $\left.40^{\circ} \mathrm{C}\right)$ por 15 minutos. Em seguida realizou-se a lavagem em água destilada sendo então, mergulhadas rapidamente em solução de álcool 95\%, e em seguida mergulhadas também rapidamente em solução de álcool pícrico por 30 segundos. As lâminas foram então, submetidas à nova lavagem em água deslitada e a Mistura de Ponceau por 12 minutos. Os cortes foram mergulhados rapidamente em água acetificada a 1\% (solução de ácido acético glacial diluído em água destilada) e submetidos à solução de Ácido fosfomolibídico a $1 \%$ por 15 minutos. Nova lavagem em água destilada foi realizada e os cortes foram submetidos à solução de Azul de anilina por 3 minutos, seguida por lavagem rápida em água acetificada à $1 \%$, submetidas à solução de Ácido fosfomolibídico por 2 minutos e nova lavagem rápida em água acetificada a $1 \%$. A seguir foi realizada nova desidratação através de três banhos de álcool absoluto I, II e III por 3 minutos em cada e três banhos de xilol I, II e III também por 3 minutos cada. Finalmente, as lâminas foram cobertas com lamínulas montadas com Entellan (Merck).

Para a coloração por Picrus sirus, os cortes hidratados foram submetidos à coloração pôr Picrus sirus $0,1 \%$ por 45 minutos. Em seguida, realizou-se a lavagem das lâminas em água destilada, sendo então, mergulhadas rapidamente em solução de ácido clorídrico a $1 \%$ diluído em álcool a $70 \%$. As lâminas foram então, submetidas à nova lavagem em água deslitada e à solução de etanol a $70 \%$ por 45 segundos. A seguir foi realizada nova desidratação através de três banhos de álcool absoluto I, II e III por 3 minutos cada e três banhos de xilol I, II e III também por 3 minutos cada. Finalmente, as lâminas foram cobertas com lamínulas montadas com Entellan (Merck). 
Terminada a montagem e secagem das lâminas, estas com os respectivos cortes corados foram rotuladas, onde os cortes foram identificados, e, posteriormente, foram acondicionadas em caixas apropriadas e armazenadas em ambiente seco e fresco, estando, finalmente, prontos para exame histológico ao microscópio de luz e luz polarizada.

\subsubsection{Processamento para imunoistoquímica}

Os cortes histológicos foram desparafinizados em xilol e hidratados em série decrescente de etanol $\left(100^{\circ}-100^{\circ}-100^{\circ}-90^{\circ}-70^{\circ} \mathrm{GL}\right)$. A recuperação antigênica foi realizada através da imersão das lâminas histológicas em solução tampão (Diva Decloaker ${ }^{\circledR}$, Biocare Medical, CA, USA), em câmara pressurizada (Decloaking Chamber®, Biocare Medical, CA, USA), a $95^{\circ} \mathrm{C}$, por 10 minutos. Ao término de cada uma das etapas da reação imunoistoquímica as lâminas contendo os cortes histológicos foram submetidas a três lavagens em tampão fosfato salino (PBS) $0,1 \mathrm{M}$, $\mathrm{pH} 7,4$. Os cortes histológicos foram imersos em $3 \%$ de peróxido de hidrogênio por 1 hora e, na seqüência, em $3 \%$ de soro albumina bovino por 12 horas, para o bloqueio da peroxidase endógena e bloqueio dos sítios inespecíficos, respectivamente. Lâminas histológicas contendo amostras de todos os grupos experimentais foram divididas em dois lotes, e cada lote foi submetido à incubação com um dos seguintes anticorpos primários: anti-Runx-2 do rato gerado em cabra (1:100; Santa Cruz Biotechnology, CA, USA) e anti-TRAP do rato gerado em coelho (1:100; Santa Cruz Biotechnology, CA, USA). Os anticorpos primários foram diluídos em PBS acrescido de $0,1 \%$ Triton X-100 (PBS-TX), durante 24 horas, em câmara úmida. As secções histológicas foram incubadas no anticorpo secundário biotinilado por 2 horas e, na 
seqüência, tratadas com estreptavidina conjugada com a peroxidase da raiz forte (HRP) por 1 hora (Universal Dako Labeled (HRP) Streptavidin-Biotin Kit®, Dako Laboratories, CA, USA). Procedeu-se a revelação utilizando-se como cromógeno o 3,3'- tetracloridrato de diaminobenzidina (DAB chromogen Kitß, Dako Laboratories, CA, USA) e posteriormente contracoloração com Fast Green, para RUNX-2 ou Hematoxilina de Harris, para TRAP.

Todas as reações de imunoistoquímica foram acompanhadas por um controle negativo, usando procedimento similar com omissão dos anticorpos primários, para evitar a análise de falsos positivos e manter a fidelidade da metodologia empregada.

\subsection{Análise dos resultados}

\subsubsection{Descrição histológica}

O alvéolo foi didaticamente dividido em terço cervical, médio e apical para realizar a análise histológica e histométrica. Os eventos histológicos descritos foram observados em toda a extensão do alvéolo, ou seja, nos três terços. Para análise microscópica descritiva, foram selecionadas aleatoriamente dez lâminas, contendo três cortes corados em cada uma, totalizando 30 cortes para cada tempo experimental.

Os cortes corados pela técnica de H/E e TM foram analisados, por um único avaliador calibrado e cego ao tratamento realizado, através da microscopia de luz com a descrição das características do processo de reparo ósseo, revascularização e neoformação óssea na região da exodontia. Para análise das fibras colágenas foi utilizada a coloração de Tricrômico de Masson (TM) e Picrus Sirus (PS). 
A leitura das estruturas histológicas foi realizada com o auxilio do microscópio óptico HM-LUX (Wild Leitz, Periplan), com as seguintes resoluções: 10 NF X 3.2, para visualização panorâmica do preparo histológico; 10 NF x 20, para identificação e visualização das estruturas do osso neoformado e 10 NF X 40, para identificação das células e demais estruturas.

Após a análise, as imagens histológicas em H/E, TM e imunoistoquímica foram capturadas para análise, com o auxílio do microscópio Olympus BX-BX61 (Olympus, Tokio, Japão) acoplado a uma câmera de captação de imagem (Olympus, Tokio, Japão) conectada a um microcomputador DELL ${ }^{\circledR}$ (Dell Inc., Round Rock, USA), com software DP2-BSW ${ }^{\circledR}$ (Olympus) para captura e análise de imagens digitalizadas. Para a análise da coloração Picrus Sirus foi utilizado o microscópio Carl Zeiss Microimaging GmbH (Zeiss, Göttingen, Germany) conectada a um microcomputador DELL ${ }^{\circledR}$ (Dell Inc., Round Rock, USA), com software Axio Imager Z2 para captura e análise de imagens digitalizadas, utilizando a luz polarizada para a captura das imagens.

O objetivo da análise histológica foi investigar os eventos morfológicos que ocorreram no interior do alvéolo dental, focando na presença de remodelação óssea. A vitalidade do tecido conjuntivo e ósseo foi observada por meio da análise microscópica com auxílio do microscópio de transmissão de luz e considerou-se como critério de avaliação qualitativa a observação de tecido conjuntivo com presença de camada de osteoblastos delimitando as bordas ósseas, com vasos sanguíneos, fibroblastos e outros tipos celulares na porção central desse tecido, áreas de fibras colágenas, presença ou não de processo inflamatório, formação e organização do tecido conjuntivo, ósseo e medular, e remodelação óssea. 
Para a histometria a região do terço médio dos alvéolos mésio-vestibular e mésio-palatina foi escolhida. O terço médio foi utilizado para a análise, pois, o processo de reparo alveolar ocorre de maneira mais homogênea nesta região (Okamoto e de Russo, 1973; Carvalho e Okamoto, 1987), em virtude da interferência do ato cirúrgico no terço cervical e apical, respectivamente, pelo uso do instrumental para a exodontia e sonda exploradora na curetagem alveolar.

\subsubsection{Critérios Morfológicos}

Os critérios morfológicos adotados para identificação dos tipos celulares avaliados foram os seguintes:

Osteoblastos: células ósseas dispostas na superfície óssea, lado a lado, num arranjo que lembra o epitélio simples. Em intensa atividade sintética mostramse cubóides e com citoplasma muito basófilo e em estado pouco ativo são achatados e apresentam fraca basofilia citoplasmática.

Osteócitos: células ósseas presentes nas lacunas no interior da matriz óssea.

Osteoclastos: células ósseas multinucleadas responsáveis pela reabsorção da matriz óssea mineralizada e desmineralizada.

Fibroblastos: são as células mais comuns do tecido conjuntivo, apresentam intensa atividade de síntese, e, sua função é formar a substância fundamental amorfa e são capazes de modular sua capacidade metabólica. 
Linfócitos: é um tipo de leucócito (glóbulo branco) presente no sangue, e tem um papel importante na defesa do corpo.

Histiócitos: são macrófagos inativos, fixos, com os pseudópodes retraídos e com aspecto ovóide.

Neutrófilos: são leucócitos polimorfonucleados e estão envolvidos na defesa do organismo.

Macrófagos: células de grandes dimensões do tecido conjuntivo, ricos em lisossomas, que fagocitam elementos estranhos ao corpo e intervêm na defesa do organismo contra infecções.

\subsubsection{Análise histométrica}

Para a realização da análise histomorfométrica, foi utilizado o método "estereológico" ou "casualização de amostra" que consiste em determinar parâmetros quantitativos tridimensionais de estruturas anatômicas a partir de cortes histológicos, com intuito de eliminar a ocorrência de vício na amostragem. O referido método baseia-se no princípio geométrico-estatístico, derivados da probabilidade das imagens e dos perfis da estrutura no corte histológico, resultando num sistemateste efetivo. Portanto, realizaram-se os procedimentos de escolhas aleatórias para as seguintes fases do experimento: seleção dos animais, dos blocos histológicos, das lâminas histológicas, dos cortes e campos histológicos.

Todas as medidas foram realizadas por um mesmo pesquisador que desconhecia os grupos experimentais e os tratamentos realizados. O pesquisador foi 
submetido a um rigoroso processo de calibração pela repetição de mensurações, em um intervalo de 48 horas, utilizando $10 \%$ do total das imagens digitais, selecionadas aleatoriamente. A calibração foi aceita se a concordância existente entre as medidas iniciais e aquelas realizadas após 48 horas era maior ou igual a $90 \%$.

\subsubsection{Análise histométrica em cortes histológicos}

Para avaliação histométrica foram utilizados os cortes corados pelo método de Hematoxilina-eosina e tricrômico de Masson, onde foram analisados os seguintes eventos: 1) formação de tecido ósseo; 2) grau de inflamação; 3) amadurecimento de colágeno. Estes eventos foram codificados em percentagem e escores e submetidos à análise estatítica. A lâmina mais central de cada peça, que correspondia ao terço médio do alvéolo, foi selecionada e serviu também como guia para a escolha dos outros cortes, assim, duas lâminas diretamente antes e duas lâminas diretamente depois foram selecionadas para a análise histométrica dos parâmetros pré-definidos usando um programa de análise de imagens IMAGE J 1.28u (programa de domínio público desenvolvido por Wayne Rasband NIMH, NIH, U.S.A.), totalizando 5 lâminas (10 cortes histológicos) por animal, de tamanhos idênticos.

\subsection{Análise histométrica da formação óssea}

Para os cortes corados por H/E e Tricrômico de Masson foi realizada uma análise quantitativa do tecido ósseo neoformado no alvéolo em $\mu \mathrm{m}^{2}$ com o auxílio do Software IMAGE J) seguindo a metodologia de César-Neto et al., 2006. Após exclusão, da primeira e da última secção na qual a região de furca foi evidente (terço 
médio do alvéolo), cinco secções equidistantes de cada animal foram selecionadas para análise histométrica. Por meio de uma objetiva de aumento de 100x Olympus (Olympus BX-BX61, Tokio, Japão) as imagens foram capturadas, salvas em formato de figura (.tif) e transferidas para o software IMAGE J. Sempre usando os recursos do software IMAGE J, procedeu-se ao cálculo da Área Total (AT) e da área de Osso Neoformado (AON), transferindo os valores medidos para uma "Planilha de Cálculos".

Para a análise histométrica, foi realizada a individualização e delimitação da área do alvéolo dentário. Esta área foi denominada de Área Total (AT) sendo que esse valor foi considerado como $100 \%$ da área total do alvéolo analisada. A seguir o cálculo da área de Osso Neoformado (AON), anteriormente delimitada, também foi obtido. Para isto, dentro da Área Total (AT), realizou-se a delimitação das várias áreas correspondentes ao osso neoformado (Figura 2). Este tecido ósseo presente no campo foi delimitado manualmente e foi obtido o "Cálculo de regiões" através da soma dessas várias áreas de formação óssea. Após a realização da histometria, os valores obtidos foram armazenados em uma Planilha de Cálculos, e descritas em gráficos para comparação de valores. 


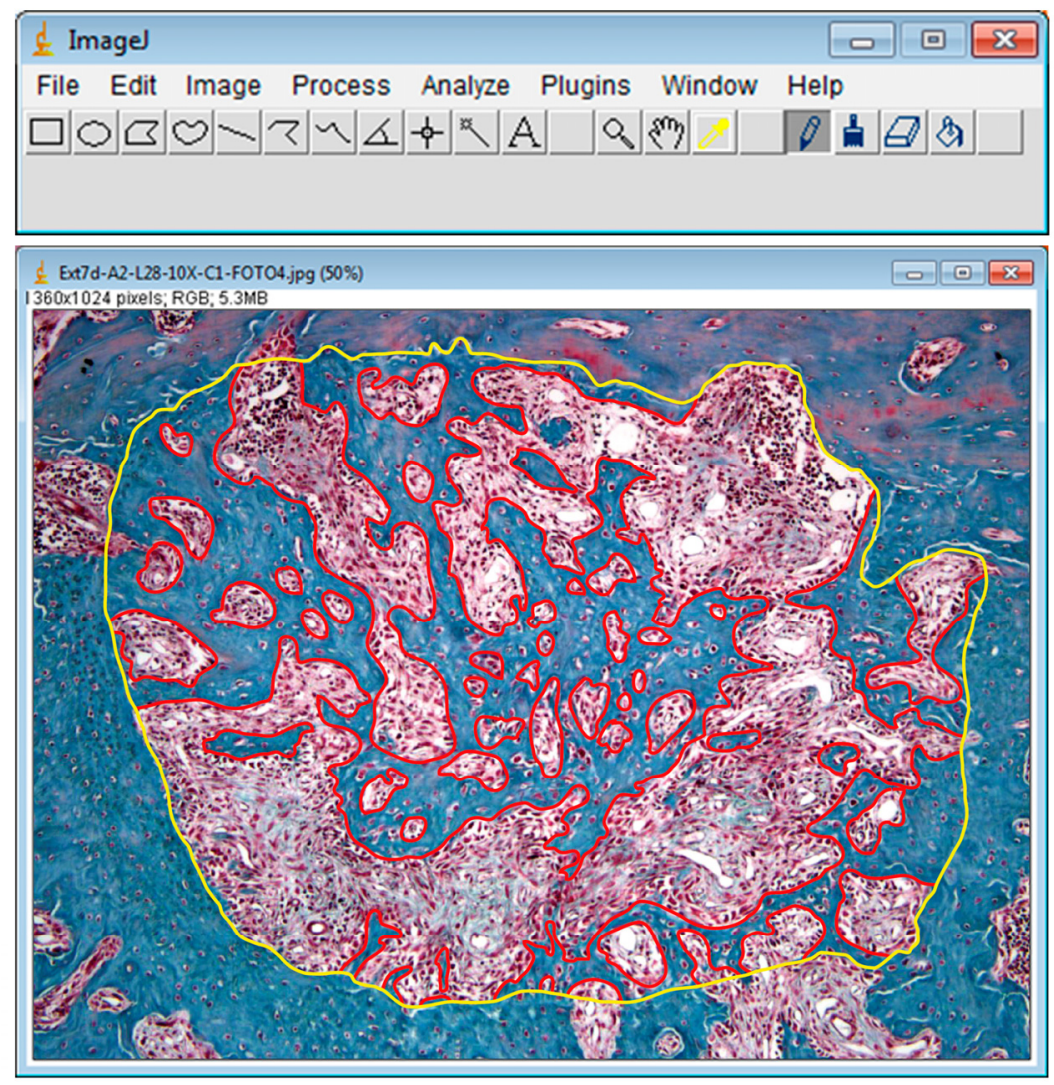

Figura 2: Foto ilustrativa de um corte histológico onde é calculado a área do alvéolo (limite amarelo) e a área de osso neoformado (limites vermelhos) utilizando o ImageJ.

O valor de osso neoformado no interior de cada alvéolo (AON) foi calculado como uma percentagem de área total do alvéolo (AT), da seguinte forma:

Medida de AT $=100 \%$ da área analisada:

$$
\text { AON } \% \Rightarrow \frac{100 \times \text { AON }}{\text { AT }}
$$

Os seguintes critérios foram usados para padronizar a análise histométrica: 1) análise de apenas cinco lâminas (10 cortes histológicos) de cada animal; 2) 
delimitação de vinte campos (alvéolo mesio-vestibular e mésio-palatino) de tamanhos equivalentes no terço médio do alvéolo, 3) padronização no tamanho e posição dos campos, 4) a área total (AT) da interface foi delineada correspondendo à área total do defeito cirúrgico, que no caso corresponde ao espaço do alvéolo dentário após a exodontia, que foi delimitada manualmente contornando a parede interna do osso alveolar. A AT foi medida em $\mu \mathrm{m}^{2}$ e considerada $100 \%$ da área a ser analisada; 5) as regiões correspondentes às áreas de osso neoformado (AON) foram delimitadas dentro da área total (AT) e esta área foi calculada pelo delineamento de cada unidade óssea separadamente em $\mu \mathrm{m}^{2}$, e então o somatório dessas unidades; 6) os valores de AON de cada animal foram usados para o cálculo das médias e dos desvios-padrões de cada grupo.

\subsection{Análise histométrica do tecido inflamatório e do colágeno}

Para os cortes corados por Hematoxilina e eosina (H/E) e Tricrômico de Masson (TM) foi realizada uma análise quantitativa do grau de processo inflamatório e do grau de amadurecimento do colágeno no interior do alvéolo com o auxílio do Software IMAGE J. A quantificação das ocorrências histomorfológicas foi baseada em critérios descritos na literatura (Wolfson e Seltzer, 1975; Dahlin et al., 1989; Hedner e Linde, 1995; Holland et al., 2007), onde foram atribuídos escores de 1 a 4 aos diferentes eventos abaixo listados (Quadro 1 e 2). Os eventos considerados para análise são: 
1) Intensidade do processo inflamatório:

Quadro 1: Escore de grau de inflamação.

\begin{tabular}{|c|c|}
\hline ESCORE & CARACTERIZAÇÃO \\
\hline 1 & Ausência ou presença ocasional de células inflamatórias \\
\hline 2 & $\begin{array}{l}\text { Pequeno número de células inflamatórias, Até } 10 \text { células/campo (aumento de } \\
100 \mathrm{x} \text { ) }\end{array}$ \\
\hline 3 & $\begin{array}{l}\text { Moderado número de células inflamatórias. De } 11 \text { a } 50 \text { células/campo } \\
\text { (aumento de 100x); }\end{array}$ \\
\hline 4 & $\begin{array}{l}\text { Grande número de células inflamatórias. Acima de } 50 \text { células/campo } \\
\text { (aumento de } 100 \mathrm{X} \text { ) }\end{array}$ \\
\hline
\end{tabular}

Adaptado de Wolfson and Seltzer (1975) e Holland et all (2007)

2) Amadurecimento de colágeno:

Quadro 2: Escore do grau de amadurecimento do colágeno (anisotropia).

\begin{tabular}{|c|l|}
\hline ESCORE & CARACTERIZAÇÃO \\
\hline 1 & Isotropia (ausência de birrefringência) (aumento de 200X), \\
\hline 2 & Anisotropia baixa (aumento de 200X), \\
\hline 3 & Anisotropia moderada (aumento de 200X), \\
\hline 4 & Anisotropia intensa (polarização total) (aumento de 200X). \\
\hline
\end{tabular}

Adaptado de Markel et al.,1991.

Para avaliar semi-quantitativamente os escores e facilitar seu entendimento foram realizados fotomicrografias de cada evento descrito acima: Assim temos:

\section{Escores histológicos}

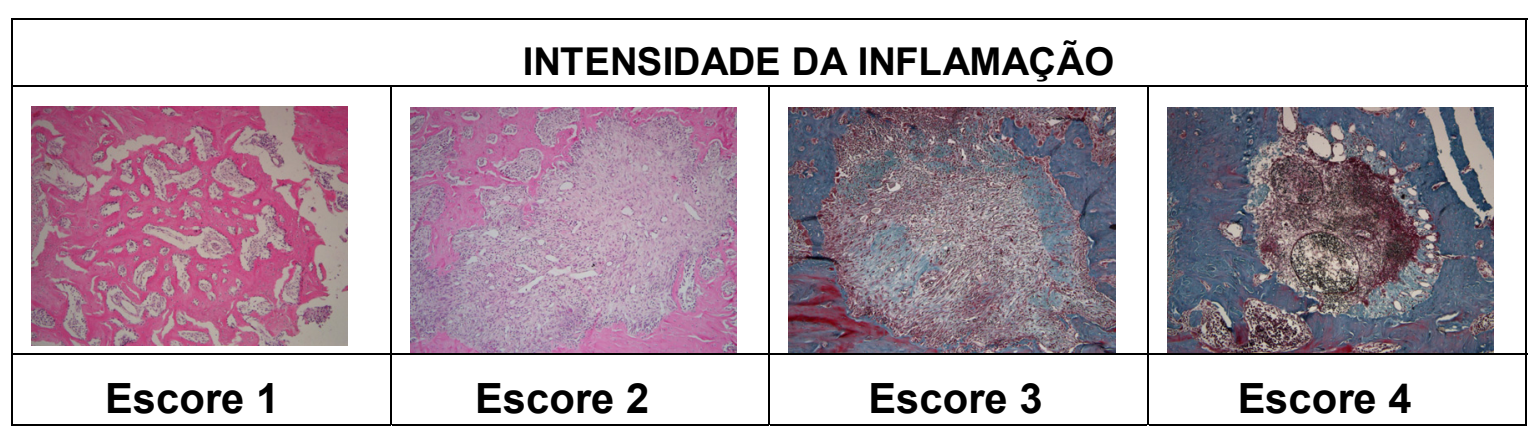




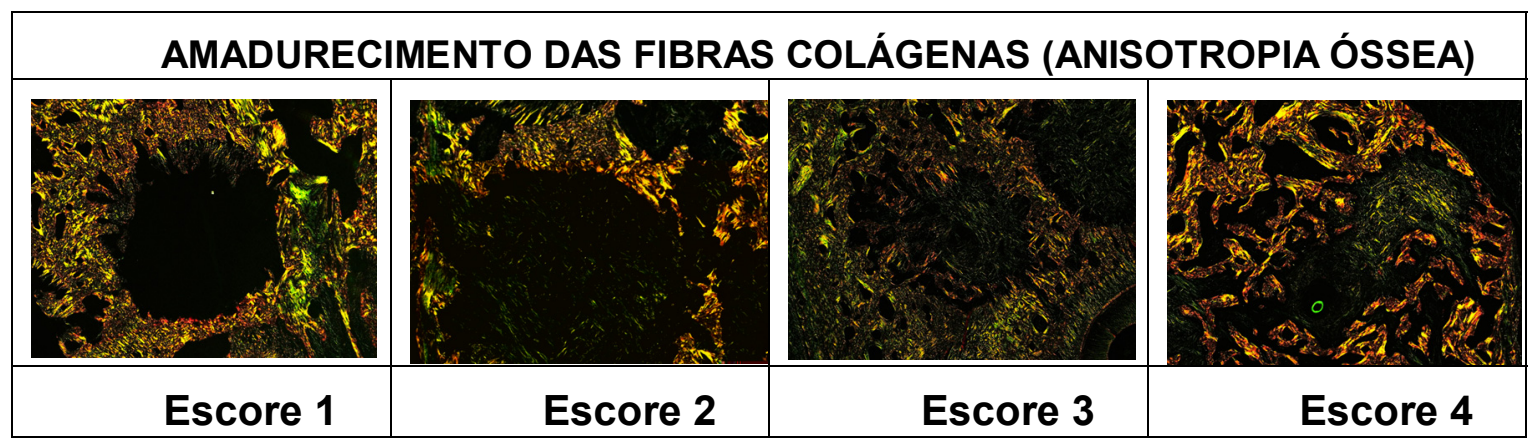

\subsubsection{Análise histológica das amostras submetidas à imunoperoxidase (Intensidade das imunomarcações para TRAP e RUNX-2)}

Os cortes teciduais submetidos à imunomarcação (cor marrom) realizada pela técnica de TRAP para células osteoclastos e RUNX-2 para células precussoras de osteoblastos, foram avaliados quanto a intensidade, presença ou a ausência das imunomarcações. Para a análise qualitativa foram levados em consideração os tipos celulares marcados positivamente pelas proteínas analisadas. As secções histológicas foram analisadas sob iluminação de campo claro em microscópio óptico (Olympus BX-BX61, Tokio, Japão) por um investigador que desconhecia os grupos experimentais que estavam sendo analisados.

Para a realização da análise semi-quantitativa foi realizada contagem do número das células imunorreativas para os anticorpos TRAP e RUNX-2 para cada grupo e período estudado. O número de osteoclastos $/ \mu m^{2}$ e células precursoras de osteoblastos $/ \mu^{2}$ do tecido ósseo na região do alvéolo dental $(\mathrm{Nm})$ foi determinada no sistema de análise IMAGE J. Foram consideradas células TRAP positivas 
osteoclastos maduros contendo três ou mais núcleos e RUNX-2 positivas células precursoras de osteoblastos. A imunomarcação foi definida como aquela de coloração acastanhada presente no compartimento nuclear das células, no caso de RUNX-2, ou no compartimento citossólico das células, no caso TRAP.

Para a contagem do número de células imunomarcadas $(n)$, foi padronizado a magnificação de 200x com o auxílio de microscopia de campo claro como recomendada por outros autores (Jin et al., 2007; Khojasteh et al., 2008; Liu et al., 2010). Cinco cortes de cada sub-grupo foram avaliados individualmente em um campo de observação (região mediana), totalizando 30 (5X6) áreas de avaliação em cada grupo, para cada proteína, selecionados por amostragem sistemática. Em cada campo foi contado o número de osteoclastos $\left(n_{c}\right)$ e células precursoras de osteoblastos $\left(n_{b}\right)$. O número de células imunomarcadas por $\mu \mathrm{m}^{2}$ da região do alvéolo $(\mathrm{Nm})$ foi calculada pela fórmula $\mathrm{Nm}=\mathrm{n} / \mathrm{A}$, sendo que: $\mathrm{A}=$ área total examinada. Cada espécime foi mensurado por um examinador calibrado em sistema de duplo cego usando método semi-quantitativo a partir de imagens capturadas no microscópio Olympus BX-BX61 (Tokio, Japão) acoplado a um computador DELL ${ }^{\circledR}$ (Dell Inc., Round Rock, USA), através do programa DP2-BSW ${ }^{\circledR}$ (Olympus).

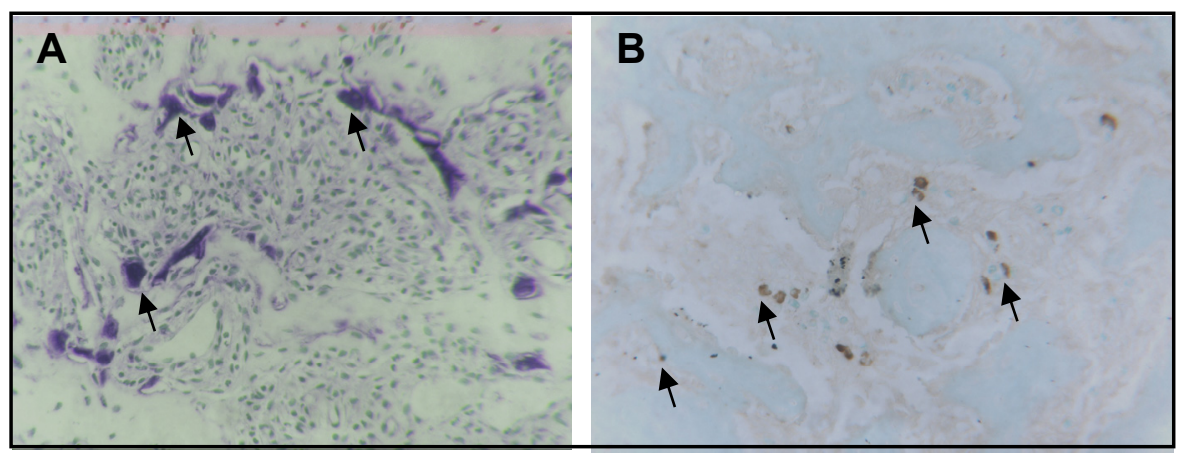

Figura 3: Foto ilustrativa de um corte histológico corado para imunoistoquímica onde em $\mathbf{A}$ as setas representam os osteoclastos (TRAP) e em B representam as células precursores de osteoblastos (RUNX-2). 


\subsection{Precisão da Metodologia (Calibração do examinador)}

Para a confiabilidade dos resultados desse trabalho, procurou-se minimizar os erros dos métodos de mensuração empregados. Calculou-se a precisão do investigador pelo erro sistemático intraexaminador. O erro sistemático reflete uma falta de padronização do método, uma vez que o examinador tende a sub ou superestimar os valores de suas medições de maneira inconsciente, de modo a direcionar os resultados de acordo com as expectativas em relação às conclusões do estudo. Para avaliar a calibração do examinador, nas mensurações de cada espécime, foi realizada, previamente às leituras finais, a correlação intraclasse. Vinte cortes foram aleatoriamente selecionados e suas contagens foram feitas e repetidas três semanas após a primeira medição pelo mesmo examinador. O teste $t$ pareado foi usado para analisar o erro intraexaminador sistemático do método, por meio da comparação dos valores das duas análises distintas com intervalo de 30 dias. Valores de $p>0,05$ foram considerados para estimar a viabilidade de utilização do método proposto. Assim, observou-se que erros na verificação da precisão desse estudo foram admissíveis, promovendo resultados fidedignos.

\subsection{Análise Estatística}

A hipótese de não haver diferença estatisticamente significante na taxa de formação óssea, processo inflamatório, amadurecimento das fibras colágenas e das imunomarcações para as proteínas TRAP e RUNX-2 na região de alvéolos dentários em regeneração entre os diferentes períodos e tipo de tratamento (laser e não-laser) 
grupos foi testada. A análise estatística dos dados histométricos obtidos foi demonstrada através da significância das diferenças entre grupos em relação às porcentagens de tecido ósseo neoformado, do número de células inflamatórias, do grau de amadurecimento de colágeno e do número de células imunorreativas para as proteínas pesquisadas. A análise estatística foi realizado com o programa de estatística GraphPad Prism versão 5 (GraphPad Software Inc., San Diego, CA), tendo sido adotado o nível de significância de $5 \%(p<0,05)$ para que as diferenças fossem consideradas estatisticamente significativas, ou seja, para rejeitar a hipótese nula.

$\mathrm{Na}$ avaliação histomorfométrica para a comparação entre os dados obtidos a partir de porcentagem (formação óssea) e número de células imunorreativas (TRAP e RUNX-2) foi tratado pelo teste ANOVA. Para a análise intragrupo (efeito do tempo) foi utilizado o teste paramétrico de análise de variância (One-Way ANOVA) e, quando detectada diferença estatisticamente significante, o teste paramétrico de Tukey-Kramer foi utilizado para detectar a diferença significativa entre os grupos dentro do mesmo ensaio. A análise intergrupo (efeito do tratamento) testou a hipótese de que a aplicação do laser de baixa potência modifica a reparação óssea por meio da alteração dos parâmetros pesquisados por meio do teste paramétrico de análise de variância (Two-Way ANOVA) e, quando detectada diferença estatisticamente significante, o teste de Kruskal Wallis.

$\mathrm{Na}$ avaliação histomorfométrica e imunoistoquímica, para a comparação entre os dados obtidos a partir da codificação (escores) dos resultados mofológicos foram tratados estatisticamente através de teste não paramétricos. Foi considerado para cada espécime os seguintes eventos histológicos: 1) Grau de inflamação e 2) Grau e amadurecimento do colágeno (anisotropia). Foi utilizado o teste não paramétrico de 
Kruskall-Wallis com finalidade de comparar os grupos, e uma vez detectada diferença estatisticamente significativa, o teste de Mann-Whitney U para comparação dois a dois com o objetivo de identificar qual grupo apresenta diferença. 


\section{Oresultados}




\section{RESULtados}

A fim de permitir a comparação, as ocorrências verificadas nos dois grupos de animais (controle e experimental) serão apresentadas juntas seguindo-se os períodos cronológicos de sacrifício dos animais. Os resultados histológicos, subdivididos nos grupos estudados, foram obtidos pela análise semi-seriada das lâminas com a coloração histológica: hematoxilina-eosina e Tricrômico de Masson. Para facilitar a comparação dos resultados o alvéolo dental foi dividido em três terços: cervical, médio e apical, considerados a partir da margem gengival, em direção ao fundo do alvéolo. Os resultados obtidos foram descritos, após análise das seguintes estruturas: mucosa gengival, restos do ligamento periodontal, tecido conjuntivo, cavidades medulares e parede alveolar.

\subsection{Descrição histológica}

\subsubsection{Análise do subgrupo 1 dia}

\subsubsection{Grupo Controle}

Após 24 horas, o espaço do alvéolo dental mostrou-se totalmente preenchido por coágulo sanguíneo, verificando-se numerosas células inflamatórias, principalmente histiócitos exibindo pigmentos de hemossiderina em seu citoplasma. 
Este processo inflamatório agudo se extendia para o interior dos espaços medulares próximos à área do local de extração, onde também foi verificado grande quantidade de células inflamatórias. Junto à parede óssea, observou-se restos do ligamento periodontal bem vascularizado e rico em fibroblastos, principalmente nos terços médio e apical. Mais próximo à margem gengival, o ligamento periodontal exibiu moderado número de polimorfonucleares e alguns linfócitos. A crista óssea alveolar, de ambos os lados mostrou uma parede íntegra, contína e lisa, onde ainda encontravam-se fibras de Sharpey inseridas, principalmente no terço apical.

\subsubsection{Grupo Experimental}

A mucosa gengival exibiu algumas células epiteliais em degeneração. O alvéolo dental de maneira semelhante ao Grupo Controle encontrou-se totalmente preenchido por coágulo sanguíneo. Próximo à margem gengival livre do alvéolo, notou-se intenso acúmulo de polimorfonucleares neutrófilos. Adjacente à cortical óssea alveolar notaram-se restos de ligamento periodontal exibindo vasos dilatados. Foi verificado o aparecimento de alguns osteoclastos principalmente no terço apical do alvéolo no interior das cavidades medulares, com início de reabsorção óssea. Estes osteoclastos também foram visualizados dentro das cavidades medulares, porém ainda em número pequeno. 

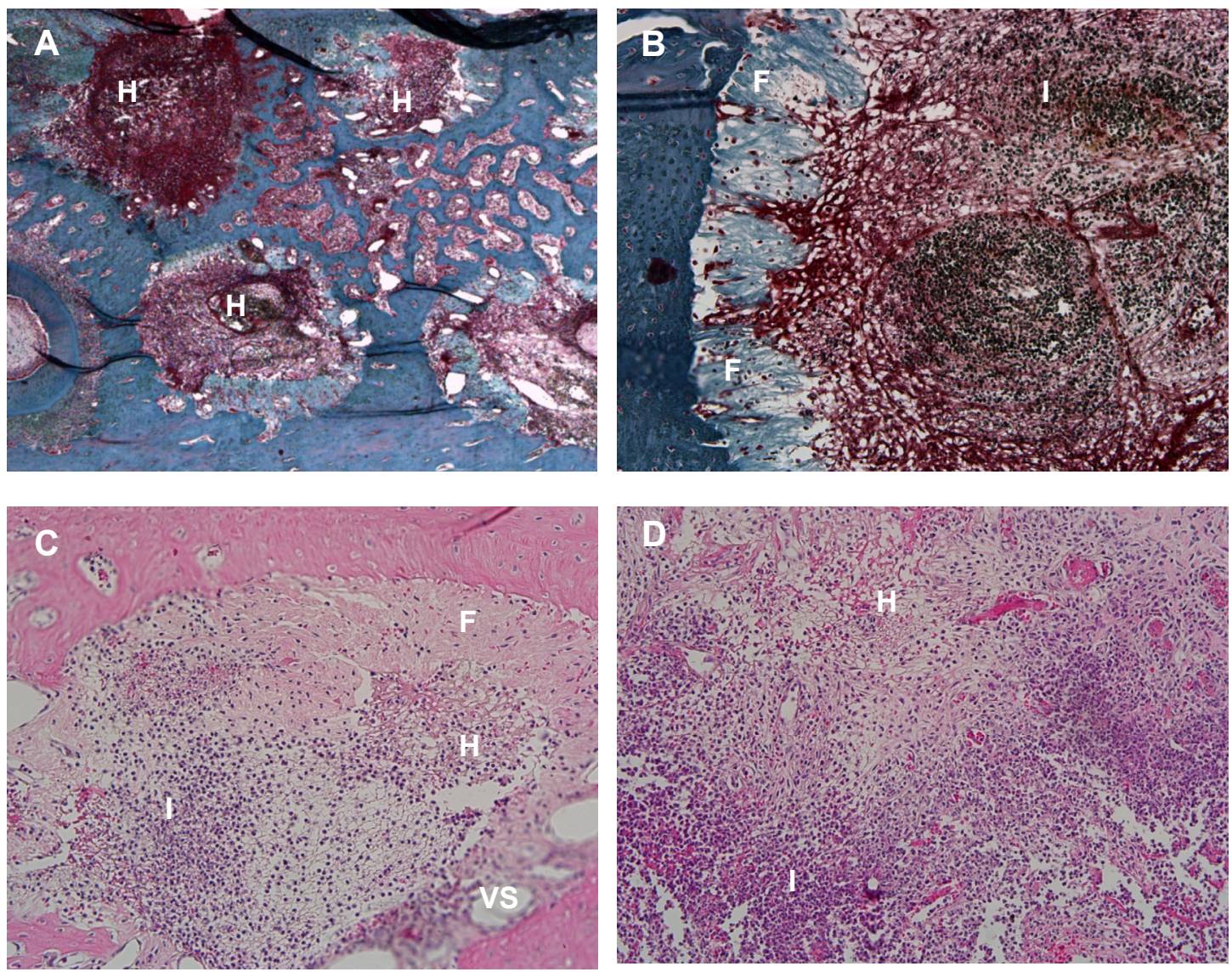

Figura 4: Fotomicrografias do Grupo Controle (1 dia). (A) Visão panorâmica da região dos alvéolos do $1^{\circ}$ molar superior direito mostrando grandes áreas hemorrágicas $(\mathrm{H})$ no interior do alvéolo (Masson, Aumento original 40X); (B) Região do terço apical do alvéolo onde observa-se processo inflamatório (I) com células em degeneração, porém próximo à parede alveolar ainda há fibras de Sharpey $(F)$ inseridas. A parede do osso alveolar apresenta-se lisa e contínua (HE, Aumento original 200X), (C) Região do terço médio do alvéolo onde observa-se processo inflamatório (I) e áreas hemorrágicas $(\mathrm{H})$ mais restrito a porção central do alvéolo, as fibras de Sharpey $(\mathrm{F})$ estavam inseridas na parede alveolar com a presença de vasos sanguíneos (VS) dilatados por entre as fibras (HE, Aumento original 100X), (D) vista aproximada do processo inflamatório (I) demonstrando algumas áreas hemorrágicas $(\mathrm{H})$ no seu interior (HE, Aumento original 200X). 

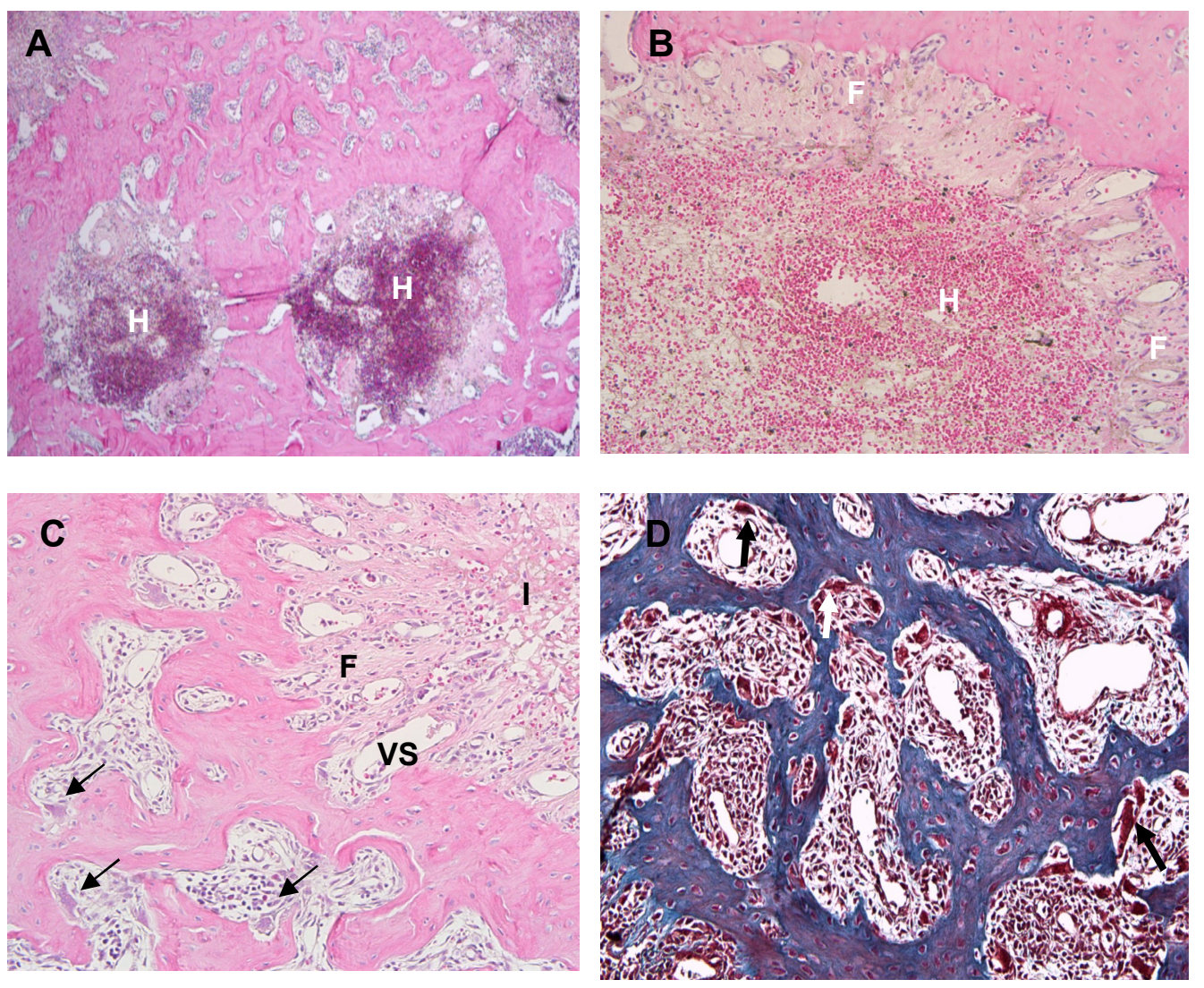

Figura 5: Fotomicrografias do Grupo Experimental (1 dia). (A) Visão panorâmica da região dos alvéolos do $1^{\circ}$ molar superior direito mostrando áreas hemorrágicas $(\mathrm{H})$ restritas à porção central do alvéolo (HE, Aumento original 40X); (B) Região do terço apical do alvéolo onde observa-se processo hemorrágico $(\mathrm{H})$ no interior do alvéolo e com algumas hemácias entre as fibras de Sharpey $(\mathrm{F})$ inseridas. (HE, Aumento original 200X), (C) Região do terço médio do alvéolo onde observa-se processo inflamatório (I) e áreas hemorrágicas porém em menor intensidade que o terço apical, as fibras de Sharpey $(F)$ estavam inseridas na parede alveolar com a presença de muitos vasos sanguíneos (VS) dilatados por entre as fibras e próximo ao osso alveolar, onde foi possível verificar a presença de alguns osteoclastos (setas) no interior das cavidades medulares (HE, Aumento original 200X), (D) vista aproximada das cavidades medulares demonstrando alguns osteoclastos (setas) no seu interior (Masson, Aumento original 200X). 


\subsubsection{Análise do subgrupo 2 dias}

\subsubsection{Grupo Controle}

Observou-se início da proliferação do epitélio da mucosa gengival sem haver, contudo, fechamento do alvéolo dental. Nas proximidades houve intensa reação inflamatória aguda, mostrando alguns neutrófilos em degeneração. Próximo ao fundo do alvéolo e adjacente à cortical alveolar dos terços médio e apical foram vistos numerosos fibroblastos invadindo o coágulo sanguíneo, além de inúmeros capilares neoformados, principalmente próximo à parede alveolar. Observou-se também, alguns neutrófilos e linfócitos e grande número de histiócitos. Ainda foi possível verificar áreas hemorrágicas, por toda a extensão do alvéolo, principalmente no terço apical do alvéolo. A crista óssea alveolar exibiu pequenas áreas de reabsorção, principalmente no terço médio, onde foram encontrados alguns osteoclastos.

\subsubsection{Grupo Experimental}

Notou-se ainda solução de continuidade do epitélio, sendo que o tecido conjuntivo adjacente apresentou processo inflamatório com predomínio de linfócitos. Verificou-se coágulo sanguíneo principalmente no terço cervical, e mais restrito à parte central do alvéolo. A presença de osteoclastos foi bem maior do que no Grupo Controle, sendo grande a presença de lacunas de Howship principalmente nos terços médio e apical, dentro das cavidades medulares. A presença de vasos sanguíneos neoformados estava presente principalmente no interior dos restos de fibras periodontais que ainda estavam inseridas o tecido ósseo. Em alguns casos, verificou-se junto aos terços médios e apicais, próximos à parede óssea, pequeno 
número de fibroblastos invadindo o coágulo sanguíneo. Estas células apresentaram citoplasma corado, núcleo volumoso e cromatina pouco condensada.
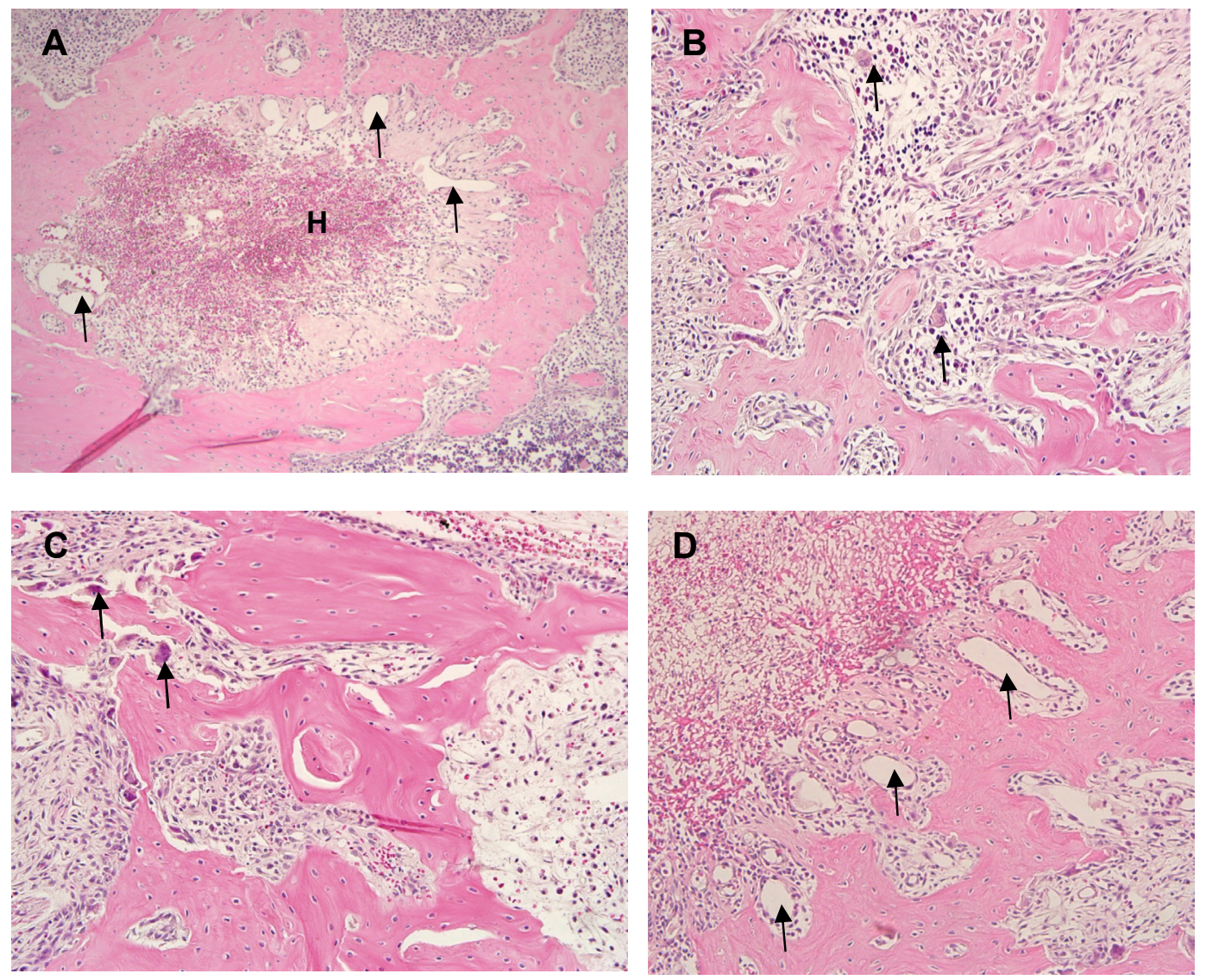

Figura 6: Fotomicrografias do Grupo Controle (2 dias). (A) Visão panorâmica da região do terço médio do alvéolo do $1^{\circ}$ molar superior direito mostrando áreas hemorrágicas $(\mathrm{H})$ ocupando grande parte do alvéolo, porém com proliferação vascular (setas) próximo ao osso alveolar (HE, Aumento original 100X); (B) Região do terço apical do alvéolo onde observa-se processo inflamatório com a presença de macrófagos (setas) (HE, Aumento original 100X), (C) Região das cavidades medulares demonstrando alguns osteoclastos (setas) no seu interior (HE, Aumento original 200X). (D) Visão aproximada do alvéolo onde algumas hemácias no interior do tecido conjuntivo e proliferação de vasos sanguíneos (setas) próximos à parede alveolar podem ser visualizadas (HE, Aumento original 200X). 

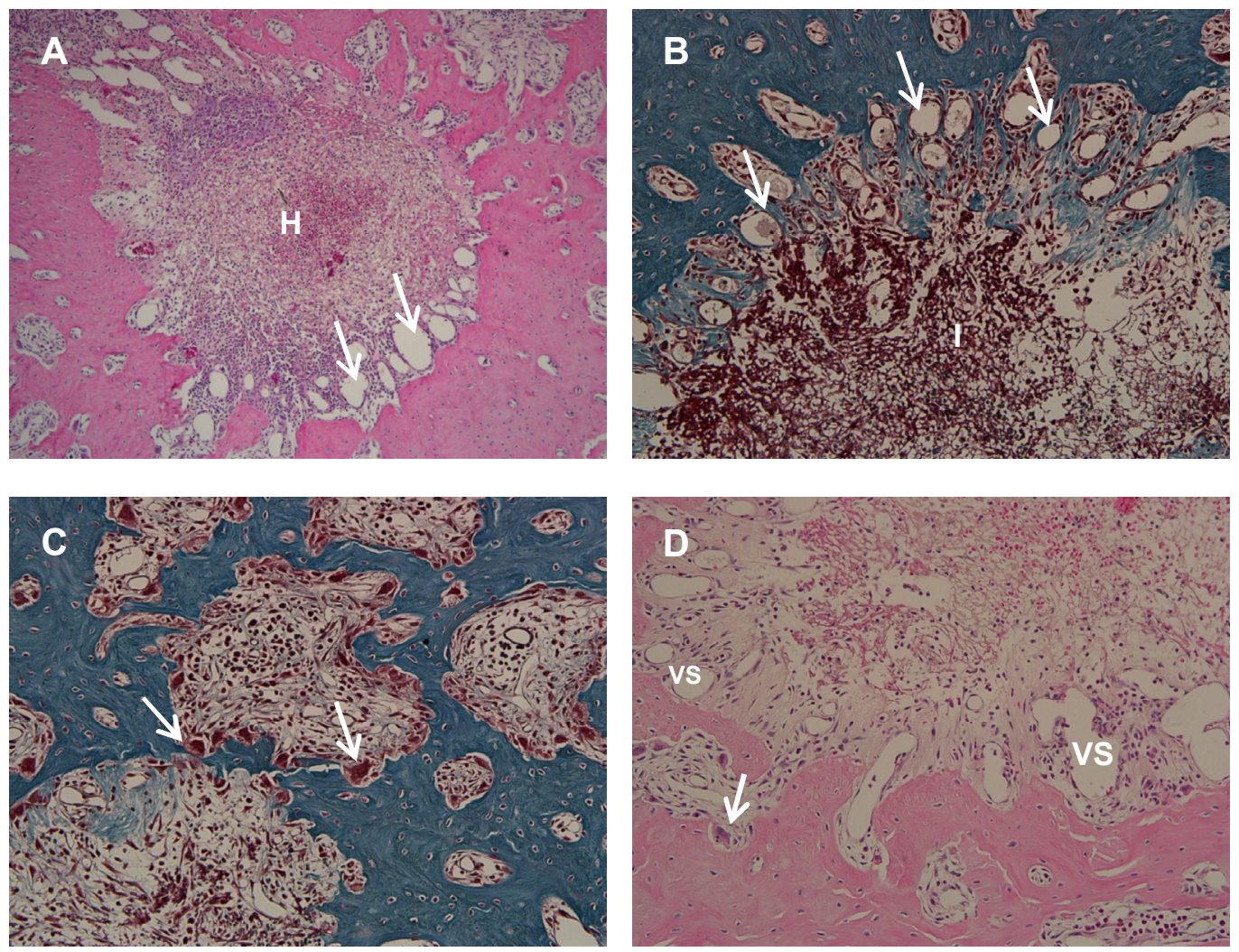

Figura 7: Fotomicrografias do Grupo Experimental (2 dias). (A) Visão panorâmica da região do terço médio do alvéolo do $1^{\circ}$ molar superior direito mostrando áreas hemorrágicas $(\mathrm{H})$ ocupando a porção central do alvéolo, porém com grande proliferação vascular e vasos sanguíneos dilatados (setas), próximos ao osso alveolar (HE, Aumento original 100X); (B) Região do terço apical do alvéolo onde observa-se processo inflamatório (I) e a proliferação de muitos vasos sanguíneos (setas) próximo ao osso alveolar (Masson, Aumento original 200X), (C) Região das cavidades medulares demonstrando osteoclastos (setas) no seu interior (Masson, Aumento original 200X). (D) Presença de vasos sanguíneos (VS) próximo ao tecido ósseo e osteoclastos (setas) no interior da cavidade medular (HE, Aumento original 200X). 


\subsubsection{Análise do subgrupo 3 dias}

\subsubsection{Grupo Controle}

No epitélio da mucosa gengival, ainda apresentando solução de continuidade, evidenciou-se discreta proliferação de células basais e o tecido conjuntivo subjacente exibe capilares neoformados, muitos fibroblastos e alguns macrófagos. $\mathrm{O}$ terço apical do alvéolo dental mostrou-se ainda preenchido por coágulo sanguíneo, exibindo numerosos macrófagos em seu interior. Junto à parede óssea nos terços médio, pôde-se observar o ligamento periodontal remanescente com moderado número de vasos sanguíneos e elevado número de fibroblastos. A grande proliferação de fibroblastos predominou neste período. A crista óssea alveolar em alguns casos apresentou discreta reabsorção com presença de osteoclastos, principalmente no interior das cavidades medulares.

\subsubsection{Grupo Experimental}

O epitélio da mucosa gengival apresentou solução de continuidade, evidenciando discreta proliferação e no tecido conjuntivo subjacente verificou-se a presença moderada de macrófagos e polimorfonucleares, e neoformação de capilares. Na região apical do alvéolo ainda havia resquício de processo inflamatório, porém a análise das cavidades das exodontias no terço médio evidenciou preenchimento por tecido conjuntivo altamente celularizado e vascularizado, com algumas áreas remanescentes de coágulo sanguíneo exibindo macrófagos, fibrina e hemácias em degeneração. O ligamento periodontal remanescente aderido à parede óssea apresentou neovascularização e elevado número de fibroblastos jovens, principalmente junto ao terço médio alveolar, onde também foi observado grande 
quantidade de histiócitos e alguns linfócitos ao longo dos três terços alveolares. A crista óssea alveolar apresentou remodelação óssea com a presença de osteoclastos, assim como no interior das cavidades medulares, em maior quantidade que o Grupo Controle.
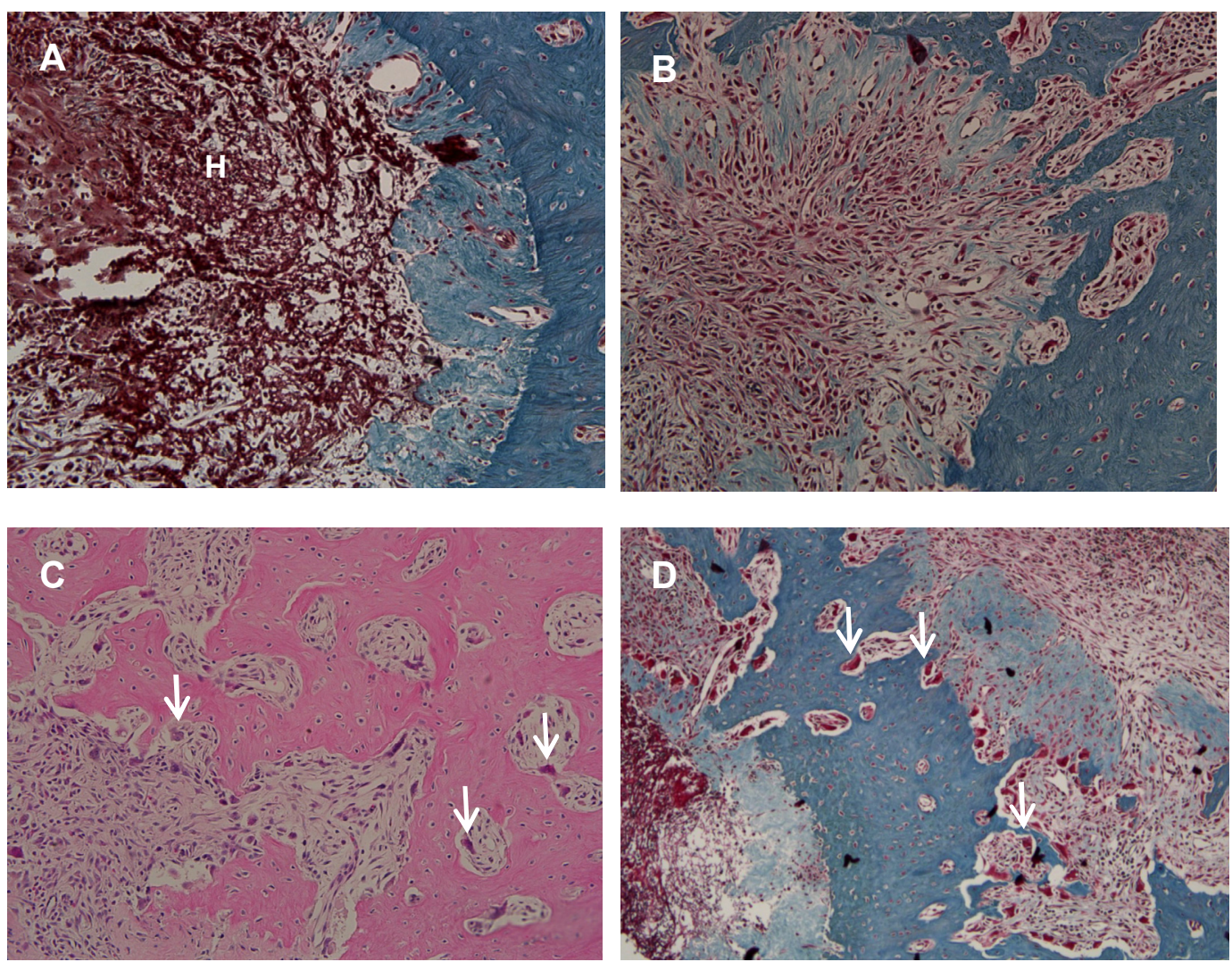

Figura 8: Fotomicrografias do Grupo Controle (3 dias). (A) Visão panorâmica da região do terço apical do alvéolo do $1^{\circ}$ molar superior direito mostrando áreas hemorrágicas $(\mathrm{H})$ ocupando grande parte do alvéolo (HE, Aumento original 100X); (B) Região do terço médio do alvéolo onde observa-se grande proliferação de fibroblastos (HE, Aumento original 100X), (C) Região das cavidades medulares demonstrando alguns osteoclastos (setas) no seu interior (HE, Aumento original 200X). (D) Região da parede alveolar mostrando a presença de osteoclastos (setas) na superfície da parede e no interior das cavidades medulares (HE, Aumento original 200X). 

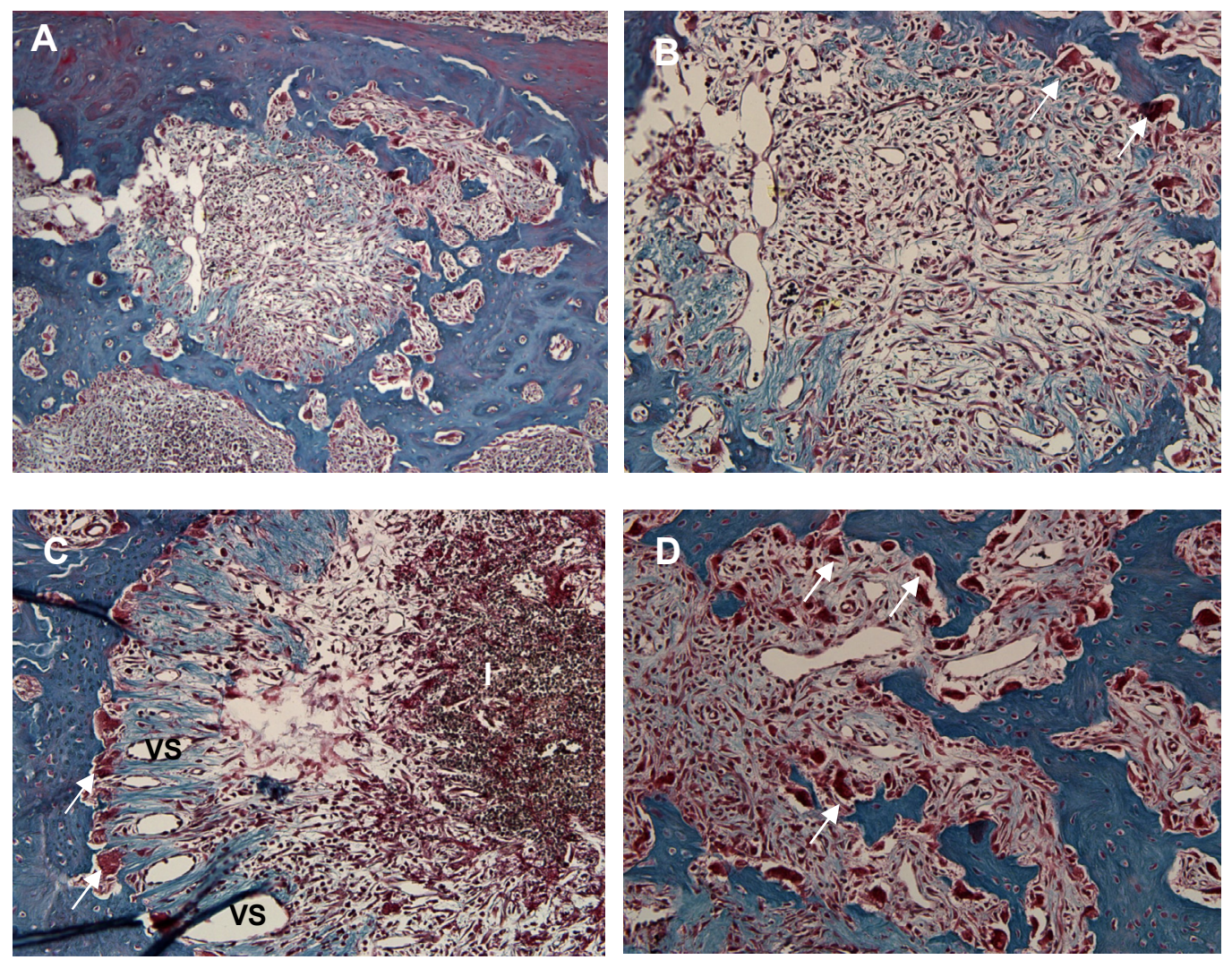

Figura 9: Fotomicrografias do Grupo Experimental (3 dias). (A) Visão panorâmica da região do terço médio do alvéolo do $1^{\circ}$ molar superior direito mostrando ausência de áreas hemorrágicas nesta região (Masson, Aumento original 100X) e em (B) Maior aumento da região anterior onde é possível verificar a grande proliferação fibroblásticas e osteoclastos (setas) foram visualizados na superfície óssea (Masson, Aumento original 200X), (C) Região do terço apical onde ainda havia pequena quantidade de tecido inflamatório (I), com grande proliferação de vasos sanguíneos (VS) e osteoclastos (setas) (Masson, Aumento original 200X). (D) Presença de osteoclastos (setas) no interior das cavidades medulares (Mason, Aumento original 200X). 


\subsubsection{Análise do subgrupo 5 dias}

\subsubsection{Grupo Controle}

O epitélio da mucosa gengival apresentou pequena solução de continuidade, em todos os espécimes, exibindo discreto infiltrado inflamatório com alguns neutrófilos e linfócitos. A análise das cavidades de extração dentária evidenciou preenchimento por tecido de granulação em vários estágios de maturação, onde ao longo dos três terços, o alvéolo apresentou-se parcialmente preenchido por tecido conjuntivo neoformado com diferentes características, rico em fibroblastos, evidenciando alguns linfócitos e histiócitos. Entretanto, o terço cervical, apresentouse ocupado por coágulo sanguíneo sem organização. A crista óssea alveolar mostrou pequenas áreas de reabsorção óssea.

\subsubsection{Grupo Experimental}

O epitélio da mucosa gengival recobria parcialmente o alvéolo. Próximo à margem gengival livre do alvéolo notou-se a presença de numerosos neutrófilos, alguns dos quais em degeneração. Nos terços médio e apical, próximo à cortical óssea alveolar, evidenciou-se em alguns pontos, tecido conjuntivo neoformado, bem vascularizado e rico em fibroblastos jovens. Em outros, no entanto, observou-se estruturas menos diferenciadas, apresentando características de tecido de granulação. Junto ao terço apical próximo à parede óssea alveolar, o tecido conjuntivo mostra-se mais diferenciado, evidenciando inclusão de espécimes ósseas neoformadas, rodeada por numerosos osteoblastos. A cortical óssea alveolar, em ambas as faces, sofreu intensa reabsorção, observando-se numerosos osteoclastos, além de polimorfonucleares neutrófilos, muitos dos quais em degeneração. 

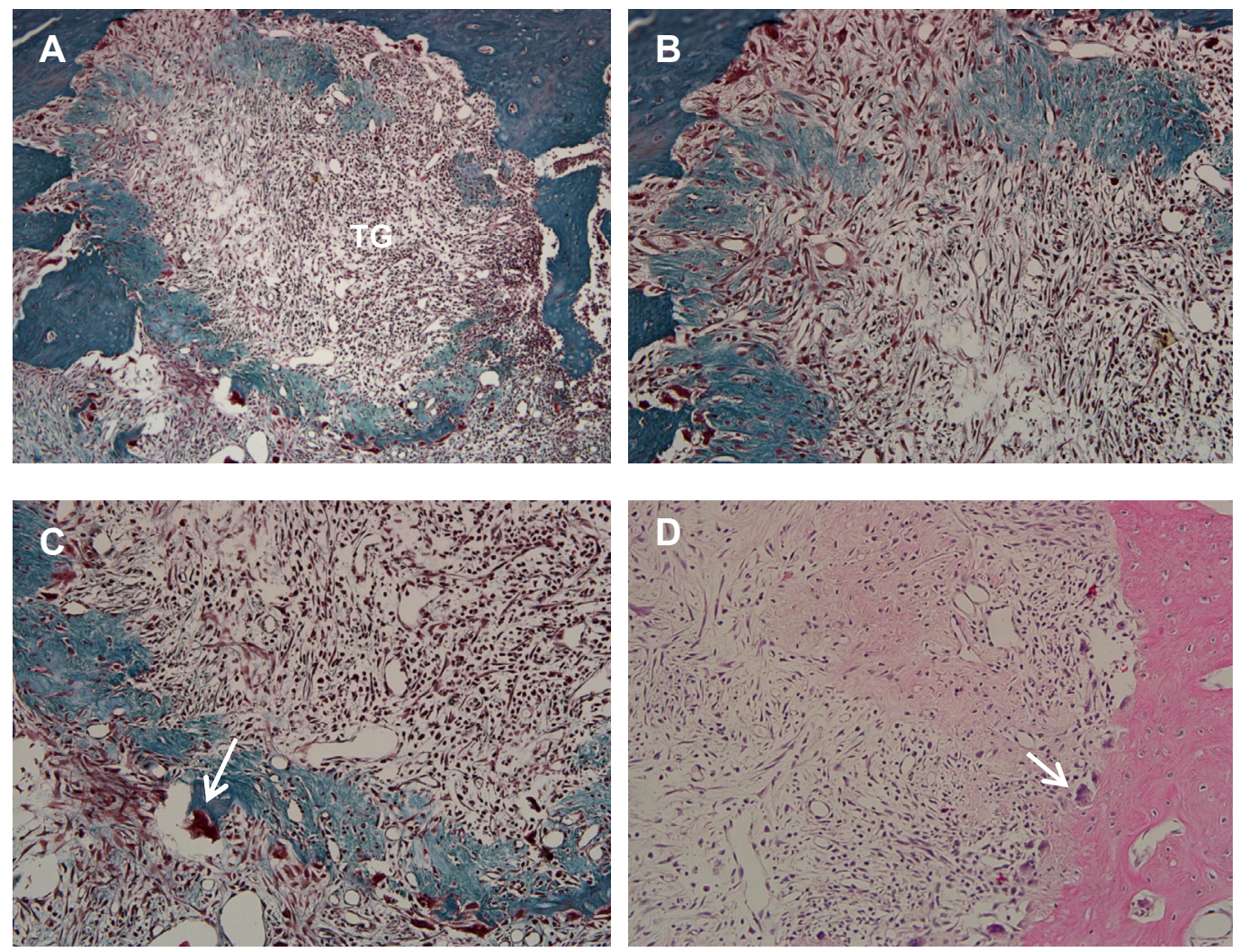

Figura 10: Fotomicrografias do Grupo Controle (5 dias). (A) Visão panorâmica da região do terço apical do alvéolo do $1^{\circ}$ molar superior direito mostrando tecido de granulação (TG) ocupando grande parte do alvéolo (Masson, Aumento original 100X); (B) Maior aumento da região (A) onde é possível visualizar a grande proliferação celular e vascular (Masson, Aumento original 200X), (C) Maior aumento da região (A) onde é possível visualizar osteoclastos (seta) no seu interior (Mason, Aumento original 200X). (D) Região da parede alveolar mostrando a presença de osteoclastos (seta) na superfície interna do alvéolo (HE, Aumento original 200X). 

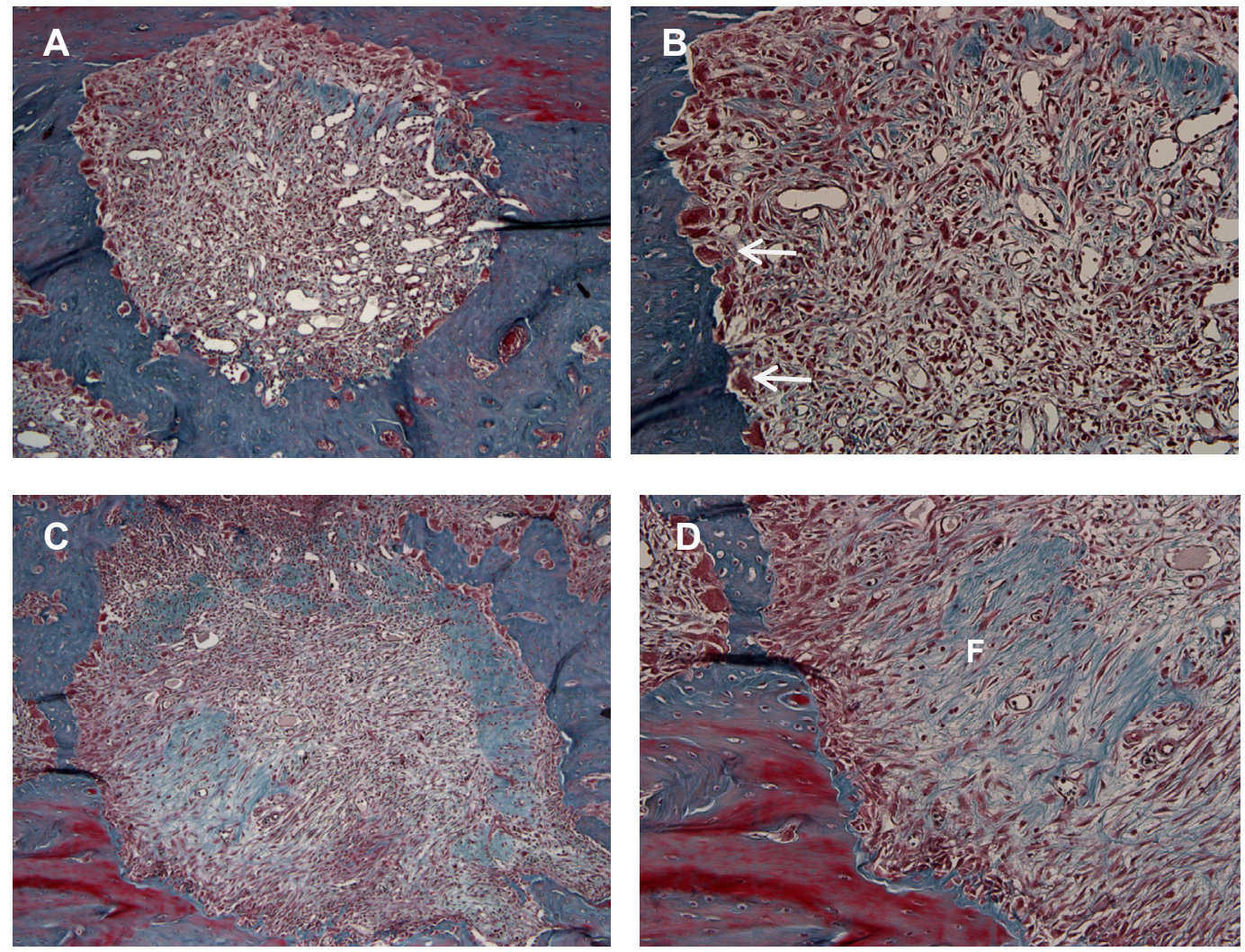

Figura 11: Fotomicrografias do Grupo Experimental (5 dias). (A) Visão panorâmica da região do terço médio do alvéolo do $1^{\circ}$ molar superior direito mostrando grande proliferação celular, vascular e presença de osteoclastos em toda parede interna do alvéolo (Masson, Aumento original 100X); (B) Maior aumento da região anterior onde é possível verificar a grande proliferação vascular e presença de osteoclastos (setas) na superfície óssea (Masson, Aumento original 200X), (C) Região do terço apical onde ainda havia tecido conjuntivo neoformado com fibras ( $F)$ e células viáveis (Masson, Aumento original 100X); (D) Maior aumento da região (C) com aglomerado de fibras neo-formadas (Mason, Aumento original 200X). 


\subsubsection{Análise do subgrupo 7 dias}

\subsubsection{Grupo Controle}

No epitélio da mucosa gengival ainda foi evidenciada discreta solução de continuidade. O tecido conjuntivo neoformado altamente celularizado com inúmeras células mononucleadas preenchendo a cavidade óssea, e fibroblastos, principalmente nas proximidades da parede óssea alveolar, com algumas pequenas áreas de coágulo sanguíneo e pequenos vasos. A disposição do tecido conjuntivo mostrou variados graus de colagenização. Junto ao terço cervical e áreas mais afastadas da parede óssea, permanece um pequeno coágulo sanguíneo ainda sem organização reacional, exibiu numerosos macrófagos em seu interior. Nos terços médio e apical pôde ser observadas, o início de formação, de delgadas trabéculas ósseas neoformadas, com numerosos osteoblastos em suas bordas. Osteoclastos inda foram visualizados na parede alveolar. O terço cervical, junto à parede óssea alveolar, mostrou a presença de tecido conjuntivo sem diferenciação óssea.

\subsubsection{Grupo Experimental}

O epitélio da mucosa gengival exibiu discreta solução de continuidade, e o tecido conjuntivo subjacente, pequeno número de linfócitos e macrófagos. A formação vascular encontrou-se mais desenvolvida do que no Grupo Controle. Ao longo dos três terços, o alvéolo dental encontrou-se parcialmente preenchido por tecido conjuntivo neoformado bem vascularizado e altamente celularizado, rico em fibroblastos, pequenos vasos sanguíneos neoformados e células inflamatórias mononucleadas, com predomínio de linfócitos, ocupando áreas mais extensas quando comparado ao Grupo Controle. Em inúmeros locais, evidenciou-se coágulo 
sanguíneo em organização com presença de macrófagos em seu interior. Nos terços médio e apical, observou-se finas trabéculas ósseas com numerosos osteoblastos em suas bordas em quantidade superior ao Grupo Controle. Junto ao terço cervical, a neoformação óssea mostrou-se menos intensa, com trabéculas ósseas mais delgadas. A crista óssea alveolar teve as mesmas características observadas no grupo anterior.
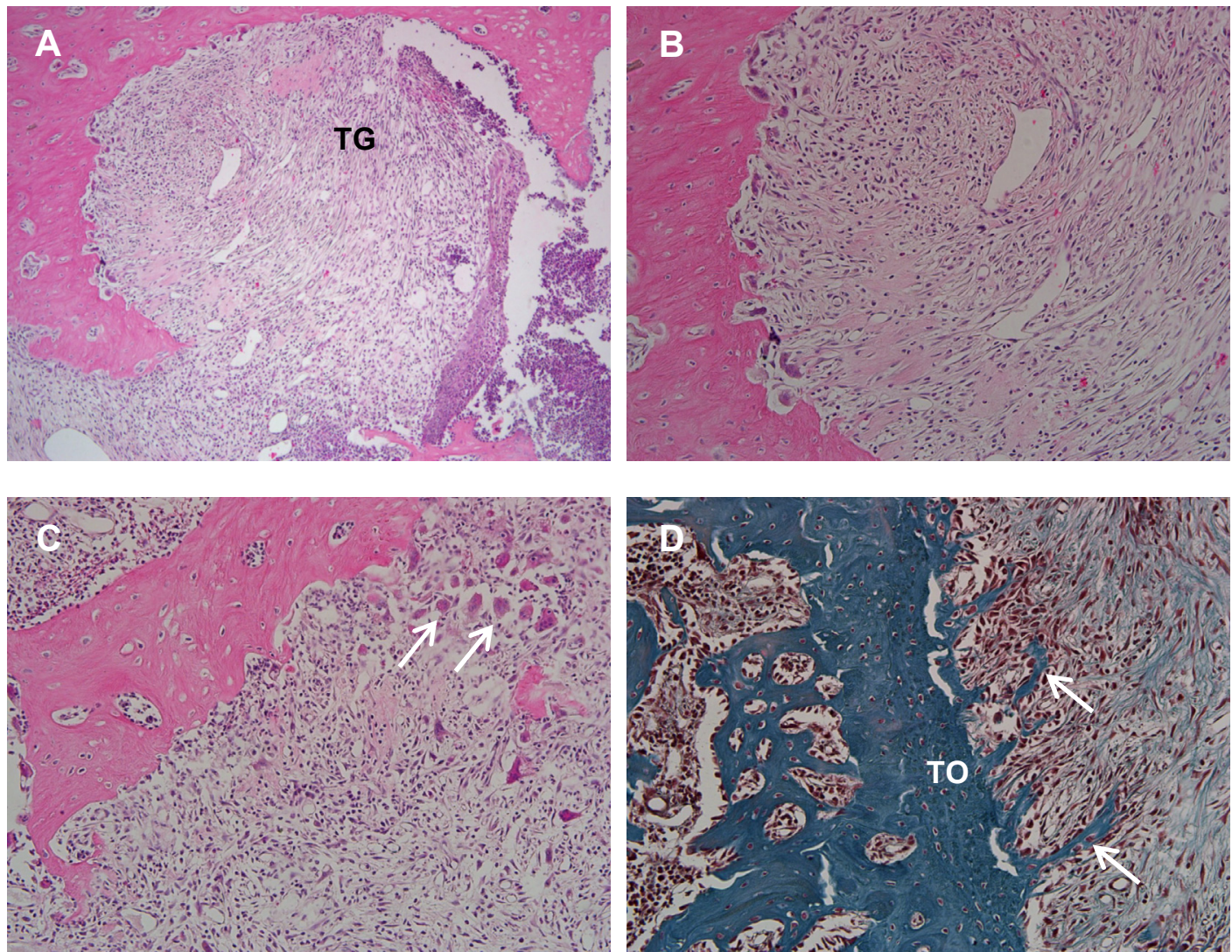

Figura 12: Fotomicrografias do Grupo Controle (7 dias). (A) Visão panorâmica da região do terço apical do alvéolo do $1^{\circ}$ molar superior direito mostrando tecido de granulação (TG) ocupando grande parte do alvéolo (HE, Aumento original 100X); (B) Maior aumento da região (A) onde é possível visualizar a grande proliferação celular, vascular e a presença de osteoclastos na parede alveolar (HE, Aumento original 200X); (C) Presença de vários macrófagos (setas) no interior do tecido de granulação próximo ao tecido ósseo (HE, Aumento original 200X); (D) Visão da parede alveolar da região média mostrando a presença de algumas trabéculas ósseas formadas em direção ao interior do alvéolo (setas) e a presença de tecido ósseo neoformado (TO) contendo osteócitos em seu interior (Mason, Aumento original 200X). 

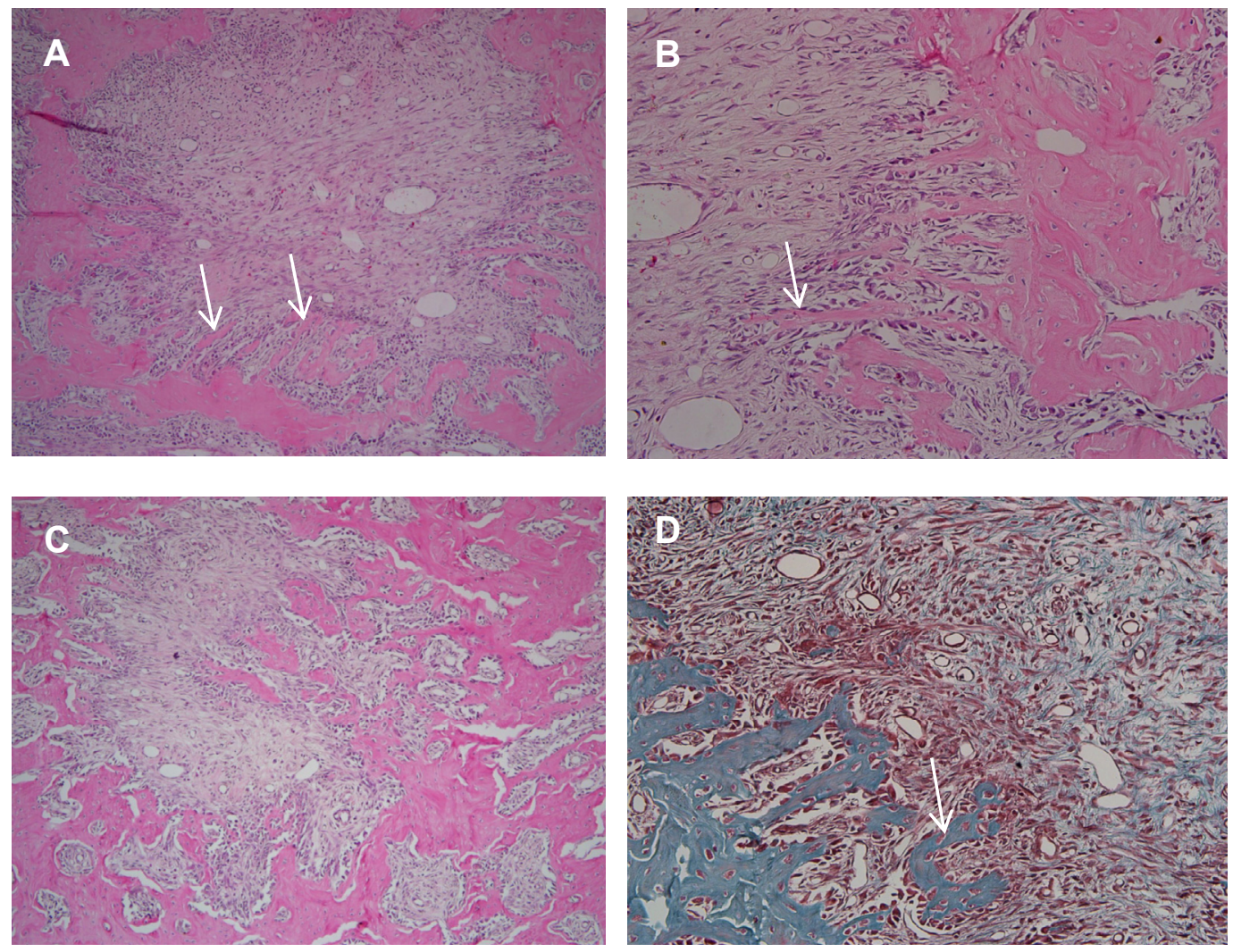

Figura 13: Fotomicrografias do Grupo Experimental (7 dias). (A) Visão panorâmica da região do terço médio do alvéolo do $1^{\circ}$ molar superior direito mostrando tecido conjuntivo ocupando todo o espaço do alvéolo dental, com a presença de trabéculas ósseas (setas) projetadas para o interior do alvéolo (HE, Aumento original 100X); (B) Maior aumento da região (A) onde é possível visualizar as trabéculas ósseas neoformadas (seta) contornadas por osteoblastos ativos (HE, Aumento original 200X), (C) Região do terço apical do alvéolo onde verificam-se várias trabéculas ósseas em direção ao centro do alvéolo, região ocupada por tecido conjuntivo (HE, Aumento original 200X). (D) Região da parede alveolar mostrando tecido ósseo neoformado (seta) contornado por osteoblastos ativos (Mason, Aumento original 200X). 


\subsubsection{Análise do subgrupo 10 dias}

\subsubsection{Grupo Controle}

A análise das cavidades de extração dentária, no tempo pós-operatório de dez dias evidenciou presença de áreas ainda bem delimitadas, onde os limites de trabéculas ósseas periféricas exibiam acentuado número de células multinucleadas da linhagem osteoblásticas. O epitélio da mucosa gengival recobria totalmente o alvéolo dental, e o tecido conjuntivo subjacente mostra-se bem desenvolvido. Em toda a extensão do alvéolo dental, observou-se tecido ósseo neoformado, porém com características distintas em cada terço. Assim, junto ao terço cervical, a ossificação foi bastante discreta, observando-se tecido ósseo pouco diferenciado caracterizado pela presença de trabéculas ósseas esparsas e imaturas, porém com intensa atividade osteoblástica em suas bordas sem, contudo definir espaços medulares em contiguidade ao tecido de granulação celularizado presente no centro do alvéolo. Foi evidenciada ainda, grande quantidade de tecido conjuntivo sem diferenciação óssea, refazendo a morfologia do alvéolo dental, muito embora esteja evidente uma redução da dimensão do alvéolo no sentido vestíbulo-lingual nesta porção alveolar. Ocasionalmente, notou-se pequena porção de coágulo sanguíneo remanescente sem organização nesta região. Os terços médio e apical encontramse preenchidos por trabéculas ósseas espessas e bem definidas com osteoblastos na periferia constituindo o início de deposição óssea no reparo tecidual, com reduzido espaço intertrabecular próximo às corticais, definindo alguns espaços medulares, enquanto que nas áreas centrais, o tecido ósseo trabecular encontra-se ainda delgado. O espaço intertrabecular encontrou-se reduzido e ocupado por tecido conjuntivo bem vascularizado e rico em fibroblastos nas áreas próximo às corticais, porém, nas áreas centrais, o tecido ósseo era menos compacto e apresentou-se 
com espaços intertrabeculares mais amplos. A crista óssea, tanto por vestibular quanto por palatina, apresentou tecido ósseo neoformado, preenchendo parcialmente áreas reabsorvidas, demonstrando atividade de remodelação óssea.

\subsubsection{Grupo Experimental}

O epitélio da mucosa gengival recobria o alvéolo dental em sua totalidade, estando o tecido conjuntivo subjacente bem desenvolvido, apresentando-se mais denso e mais vascularizado que no Grupo Controle. O alvéolo dental encontrou-se parcialmente preenchido por tecido ósseo neoformado. Nos terços médio e apical evidenciou presença de grande quantidade de trabéculas ósseas neoformadas, espessas, defenidas e regulares com osteócitos preenchendo grandes lacunas no interior da matriz orgânica óssea e muitos osteoblastos na periferia. Partes das trabéculas neoformadas já esboçavam espaços medulares definidos, contendo em seu interior tecido conjuntivo vascularizado. Estas trabéculas estavam cercadas por tecido conjuntivo bem vascularizado, caracterizado por grande número de fibroblastos em diferenciação em meio à grande quantidade de vasos sanguíneos. A neoformação óssea foi vista, principalmente próximo às corticais alveolares.

No terço cervical a ossificação foi mais discreta, com trabéculas ósseas mais delgadas, porém com intensa atividade osteoblástica. A crista óssea alveolar encontrou-se remodelada. 

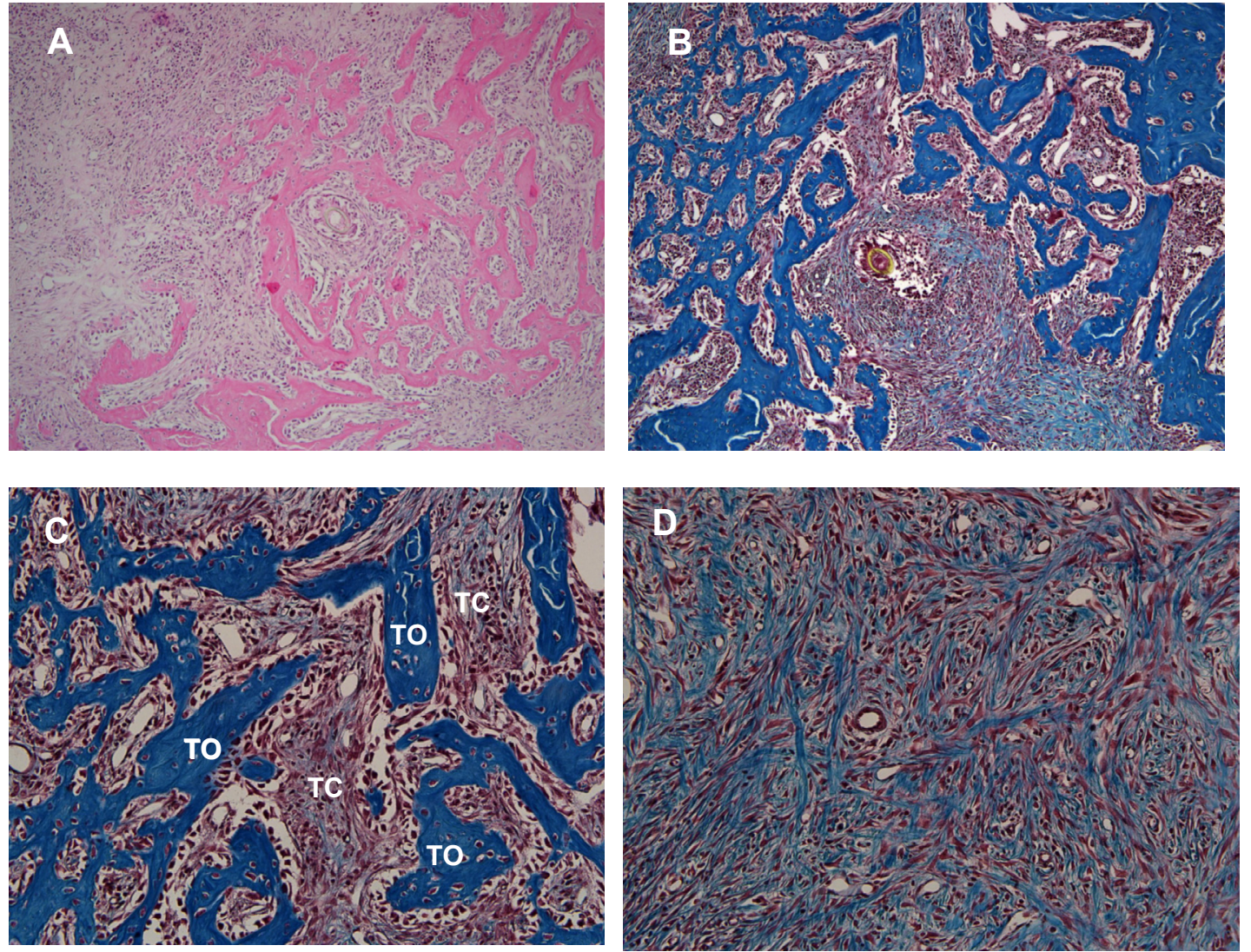

Figura 14: Fotomicrografias do Grupo Controle (10 dias). (A) Visão panorâmica da região do terço médio do alvéolo do $1^{\circ}$ molar superior direito mostrando trabéculas ósseas neoformadas em direção ao interior do alvéolo (HE, Aumento original 100X); (B) Visão panorâmica da região do terço apical do alvéolo do $1^{\circ}$ molar superior direito mostrando grande quantidade de trabéculas ósseas neoformadas em direção ao interior do alvéolo (Masson, Aumento original 100X); (C) Presença de várias trabéculas ósseas (TO) recobertas por osteoblastos ativos, contendo osteócitos em seu interior e rodeadas por tecido conjuntivo (TC) no interior do espaço alveolar na região apical (Masson, Aumento original 200X); (D) Tecido conjuntivo mais organizado composto por muitas fibras e fibroblastos ativos (Mason, Aumento original 200X). 

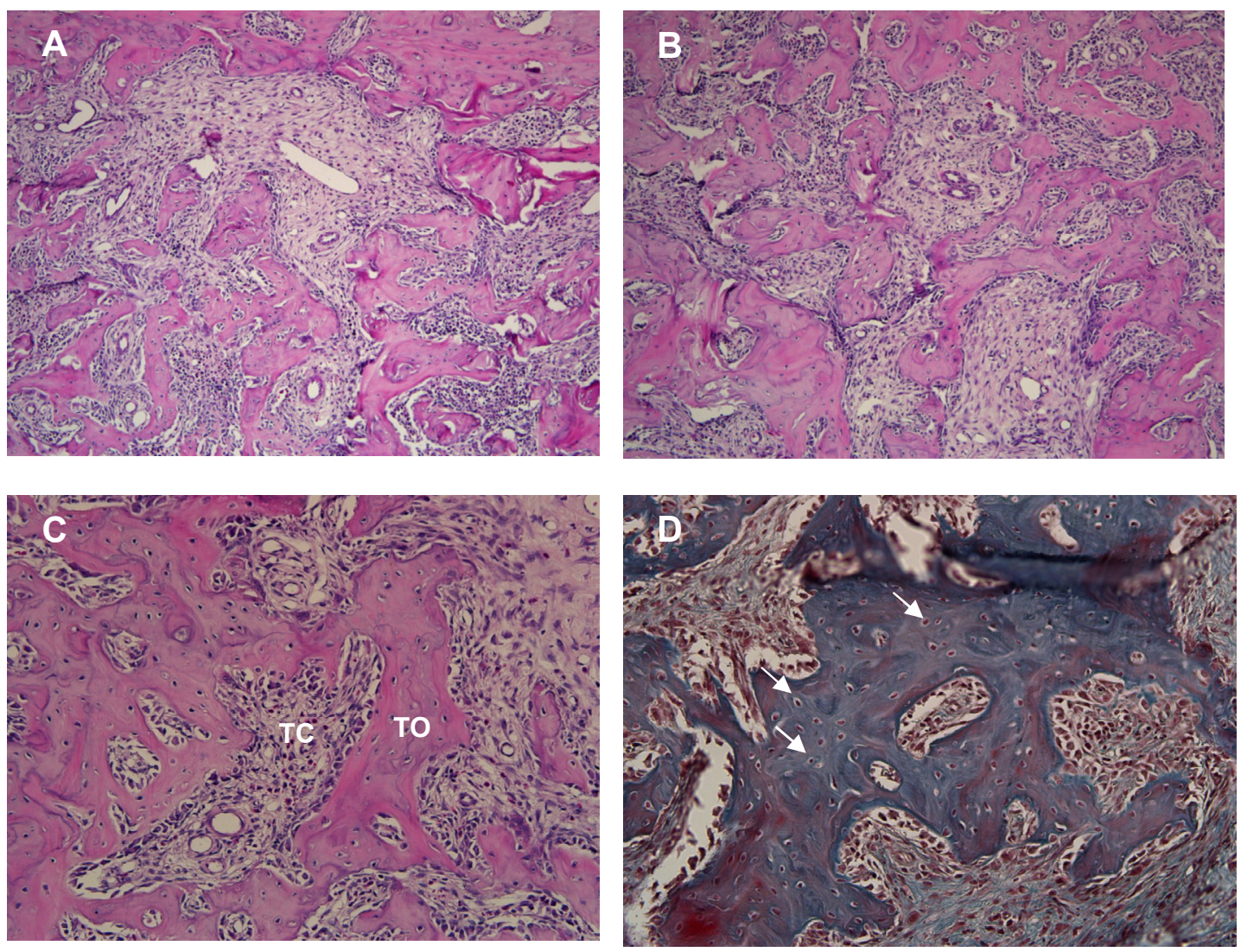

Figura 15: Fotomicrografias do Grupo Experimental (10 dias). (A) Visão panorâmica da região do terço médio do alvéolo do $1^{\circ}$ molar superior direito mostrando trabéculas ósseas neoformadas em direção ao interior do alvéolo (HE, Aumento original 100X); (B) Visão panorâmica da região do terço apical do alvéolo do $1^{\circ}$ molar superior direito mostrando grande quantidade de trabéculas ósseas neoformadas em direção ao interior do alvéolo (HE, Aumento original 100X); (C) Presença de várias trabéculas ósseas (TO) recobertas por osteoblastos ativos, contendo osteócitos em seu interior e rodeadas por tecido conjuntivo (TC) contornando novos espaços medulares na região apical (HE, Aumento original 200X); (D) Tecido ósseo neoformado contendo osteócitos ativos no seu interior (setas) (Mason, Aumento original 200X). 


\subsection{Resultados Histométricos}

\subsubsection{Resultados dos escores e estatísticos}

A seguir será apresentada a posição de cada espécime nos escores determinados. Juntamente com as tabelas serão apresentados seus respectivos gráficos com a mediana de cada grupo ilustrando apenas o resultado. Também serão apresentados os resultados estatísticos para cada variável dependente: grau de formação óssea, grau de inflamação, amadurecimento do colágeno e imunomarcação.

\section{Formação óssea:}

A quantidade de formação óssea foi obtida a partir da porcentagem de osso neoformado em relação à área total do alvéolo. Nos períodos iniciais (1, 2 e 3 dias) não houve formação óssea em nenhum dos grupos. Aos 5 e 7 dias a análise histométrica indicou que a neoformação óssea na área do alvéolo, foi significativamente maior nos grupos experimentais do que no Grupo Controle, sendo que nestes períodos os grupos experimentais apresentaram melhor resultado que o Grupo Controle, (GC 13,29\% \pm 0,83\% versus GE $26,17 \% \pm 0,70 \%$ aos 5 dias e GC $21,48 \% \pm 1,41 \%$ versus GE $30,74 \% \pm 11,36 \%$ aos 7 dias). Aos 10 dias não houve diferença significativa entre o Grupo Controle e Experimental (GC 77,13\% \pm 2,08\% versus GE $82,77 \% \pm 2,43 \%$ ). 

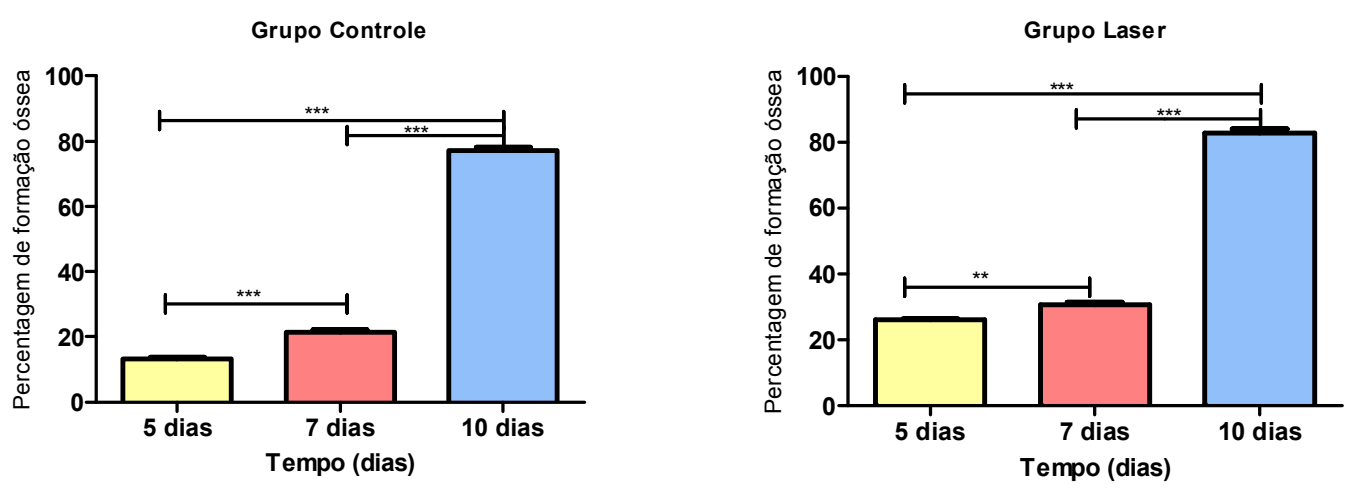

Figura 16: Expressão da percentagem média e desvio padrão da formação óssea no Grupo Controle e Experimental. Os dados correspondem a 10 dias de experimento. ${ }^{*} p<0,05 ;{ }^{* *} p<0,01$; ${ }^{* * *} p<0,001 ; p>0,05=$ não significativo.

Quadro 3: Análise de variância (ANOVA) e teste de TUKEY dos resultados histomorfométricos, referentes à percentagem de trabéculas ósseas formadas entre o Grupo Controle e Laser. Nível de significância estatística $(p<0,05)$.

\begin{tabular}{|c|c|c|c|}
\hline \multirow{2}{*}{ Grupos } & \multicolumn{3}{|c|}{ NÍVEL DE SIGNIFICÂNCIA ESTATÍSTICA (P) } \\
\cline { 2 - 4 } & 5 dias & 7 dias & 10 dias \\
\hline $\begin{array}{c}\text { Controle } \\
X \\
\text { Laser }\end{array}$ & $p<0,001$ & $p<0,01$ & $p>0,05$ \\
\hline
\end{tabular}




\section{Processo Inflamatório}

$\mathrm{Na}$ análise intra-grupo houve uma diminuição significativa do número de células inflamatórias a partir do dia 5 no Grupo Controle e a partir do dia 3 no Grupo Experimental, sendo está redução muito mais significativa no grupo irradiado. $\mathrm{Na}$ análise inter-grupo houve diferença estatística nos períodos de 3, 5 e 7 dias, sendo que no grupo irradiado a redução no número de perfis de células inflamatórias foi bem maior que no Grupo Controle.

Quadro 4: Escore individual de cada espécime e mediana de cada grupo para a intensidade do processo inflamatório em todos os períodos para o Grupo Controle e experimental.

Escore do Grau de inflamação $(1,2,3,4)$

\begin{tabular}{cccccccccccccc}
\hline & 1dia & \multicolumn{1}{c}{ 2 dias } & \multicolumn{2}{c}{ 3 dias } & 5 dias & $\mathbf{7}$ dias & \multicolumn{1}{c}{$\mathbf{1 0}$ dias } \\
\hline Animais & controle & laser & controle & laser & controle & laser & controle & Laser & controle & laser & controle laser \\
I & 4 & 4 & 4 & 4 & 3 & 3 & 3 & 2 & 3 & 1 & 1 & 1 \\
II & 4 & 4 & 4 & 3 & 4 & 2 & 3 & 2 & 3 & 1 & 2 & 1 \\
III & 4 & 4 & 4 & 4 & 4 & 3 & 4 & 3 & 3 & 2 & 1 & 1 \\
IV & 4 & 4 & 4 & 3 & 3 & 2 & 3 & 2 & 2 & 1 & 1 & 1 \\
V & 4 & 4 & 4 & 3 & 4 & 3 & 3 & 2 & 3 & 2 & 2 & 1 \\
\hline Mediana & 4 & 4 & 4 & 3 & 4 & 3 & 3 & 2 & 3 & 1 & 1 & 1
\end{tabular}

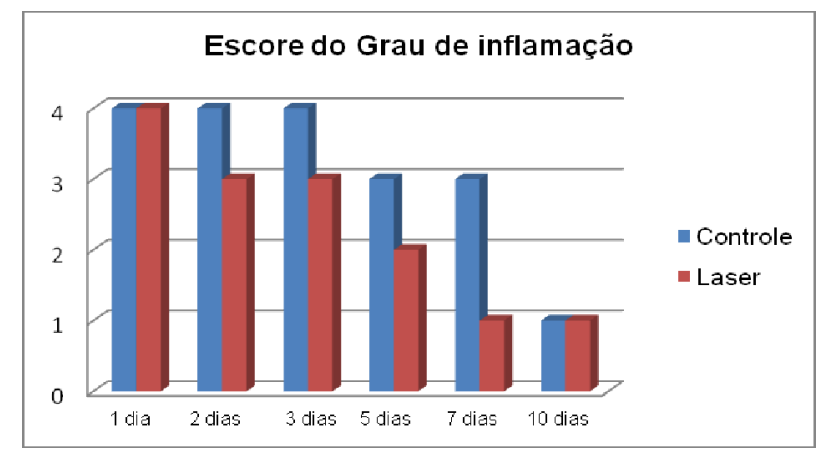

Figura 17: Gráfico de barras ilustrativo da mediana do grau para a intensidade do processo inflamatório em todos os períodos para o Grupo Controle e Experimental. 


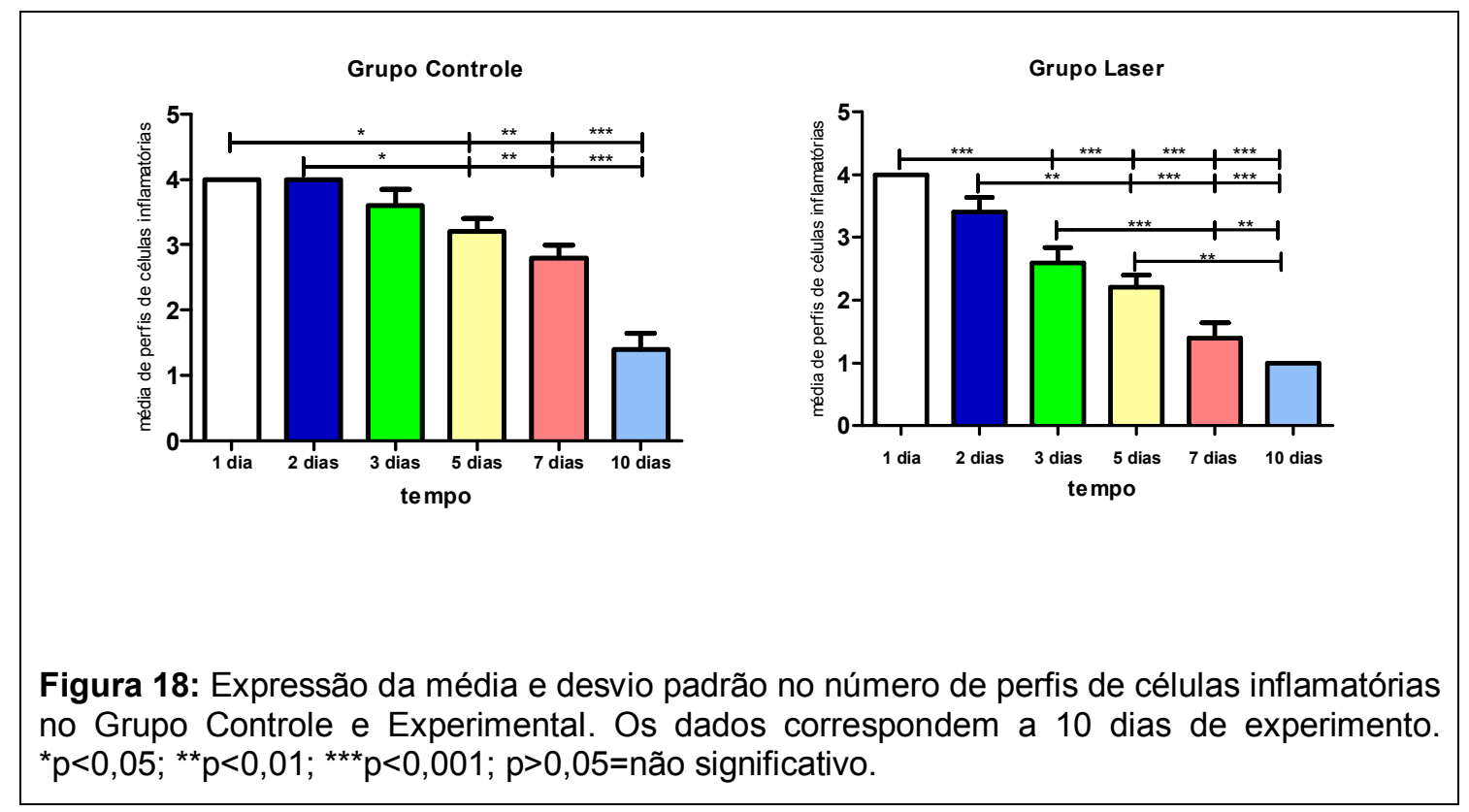

Quadro 5: Teste de Mann-Whitney para o evento grau de inflamação.

\begin{tabular}{|c|c|c|}
\hline \multicolumn{3}{|c|}{ Comparação dois a dois } \\
\hline Periodos & & \\
\hline 1 dia (ns) & $\begin{array}{l}\text { Mann-Whitney (U) } \\
\text { Valor de } p\end{array}$ & $\begin{array}{l}12,50 \\
0,061\end{array}$ \\
\hline 2 dias $(\mathrm{ns})$ & $\begin{array}{l}\text { Mann-Whitney (U) } \\
\text { Valor de } p\end{array}$ & $\begin{array}{l}5,0 \\
0,0668\end{array}$ \\
\hline 3 dias $\left({ }^{*}\right)$ & $\begin{array}{l}\text { Mann-Whitney (U) } \\
\text { Valor de } p\end{array}$ & $\begin{array}{l}3,0 \\
0,0413 \\
\end{array}$ \\
\hline 5 dias $\left(^{*}\right)$ & $\begin{array}{l}\text { Mann-Whitney (U) } \\
\text { Valor de } p\end{array}$ & $\begin{array}{l}2,0 \\
0,0209\end{array}$ \\
\hline 7 dias $\left(^{*}\right)$ & $\begin{array}{l}\text { Mann-Whitney (U) } \\
\text { Valor de } p\end{array}$ & $\begin{array}{l}1,0 \\
0,0149\end{array}$ \\
\hline 10 dias (ns) & $\begin{array}{l}\text { Mann-Whitney }(U) \\
\text { Valor de } p\end{array}$ & $\begin{array}{l}7,5 \\
0,1770\end{array}$ \\
\hline
\end{tabular}

* Nível de significância de $5 \%(p<0,05)$ 


\section{Amadurecimento do colágeno (Quadro 2).}

O amadurecimento do colágeno foi obtido através de escores, onde obtemos os seguintes resultados.

Quadro 6: Escore individual de cada espécime, da mediana de cada grupo, para a maturação do colágeno em todos os períodos para o Grupo Controle e experimental.

Escore do Grau de maturação de colágeno (anisotropia) $(1,2,3,4)$

\begin{tabular}{|c|c|c|c|c|c|c|c|c|c|c|c|c|}
\hline & \multicolumn{2}{|l|}{1 dia } & \multicolumn{2}{|c|}{2 dias } & \multicolumn{2}{|c|}{3 dias } & \multicolumn{2}{|l|}{5 dias } & \multicolumn{2}{|l|}{7 dias } & \multicolumn{2}{|c|}{10 dias } \\
\hline Animais & controle & laser & controle & laser & controle & laser & controle & Laser & controle & laser & controle & laser \\
\hline I & 1 & 1 & 1 & 1 & 1 & 2 & 2 & 3 & 4 & 4 & 4 & 4 \\
\hline II & 1 & 1 & 1 & 2 & 1 & 3 & 2 & 4 & 4 & 4 & 4 & 4 \\
\hline III & 1 & 1 & 1 & 1 & 2 & 2 & 3 & 4 & 4 & 4 & 4 & 4 \\
\hline IV & 1 & 1 & 1 & 1 & 2 & 3 & 3 & 4 & 4 & 4 & 4 & 4 \\
\hline $\mathbf{V}$ & 1 & 1 & 1 & 1 & 2 & 3 & 3 & 4 & 4 & 4 & 4 & 4 \\
\hline Mediana & 1 & 1 & 1 & 1 & 2 & 3 & 3 & 4 & 4 & 4 & 4 & 4 \\
\hline
\end{tabular}

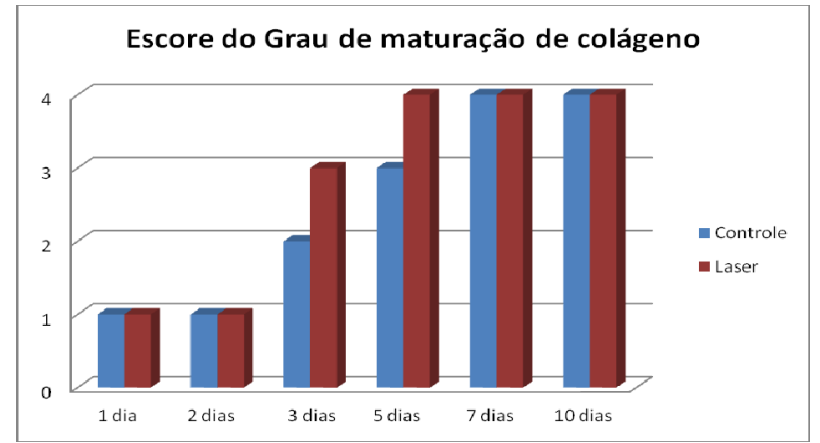

Figura 19: Gráfico de barras ilustrativo da mediana do grau de maturação de colágeno em todos os períodos para o Grupo Controle e Experimental. 

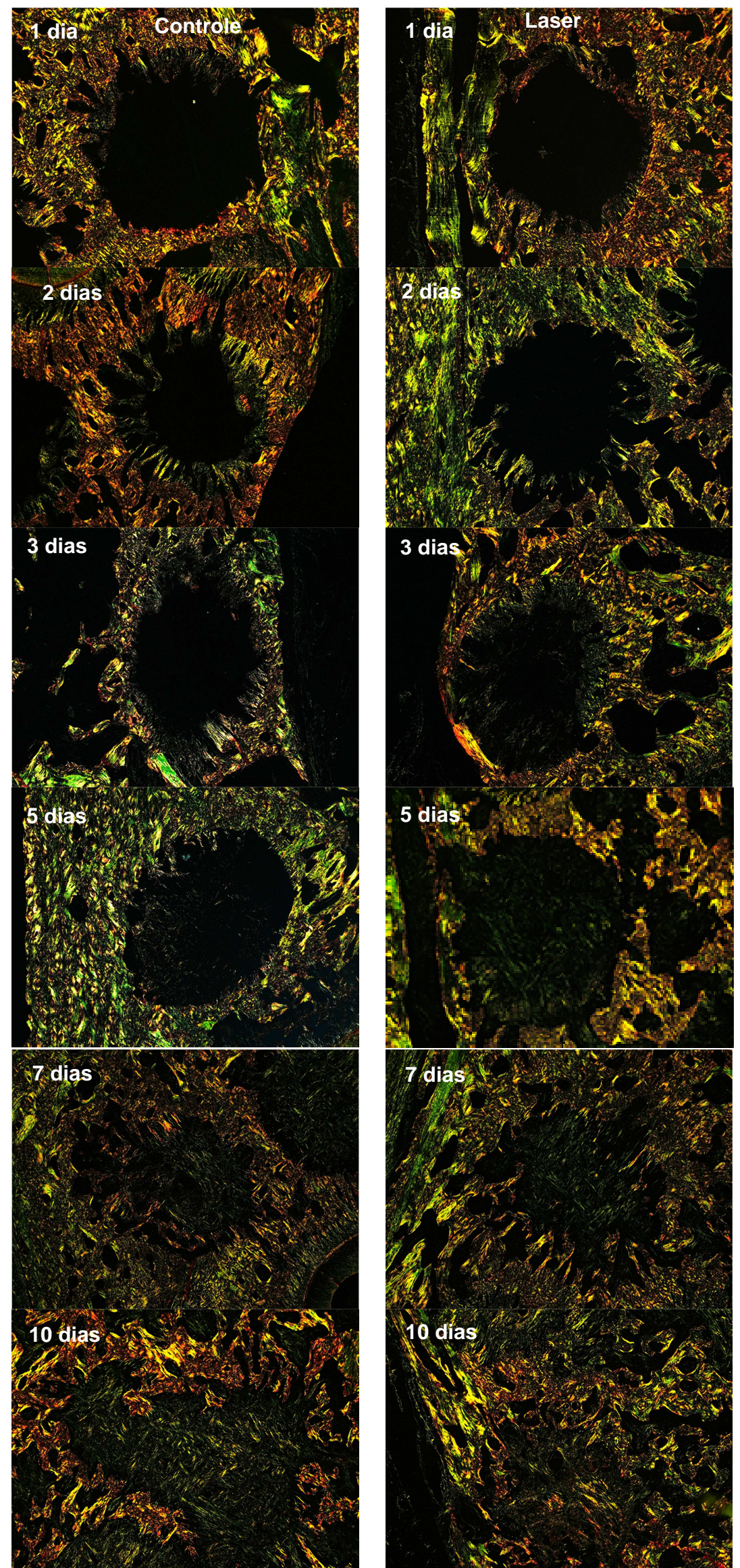

Figura 20: Fotomicrografias por luz polarizada do Grupo Controle e Experimental mostrando a maturação do colágeno (Aumento original 200X). 

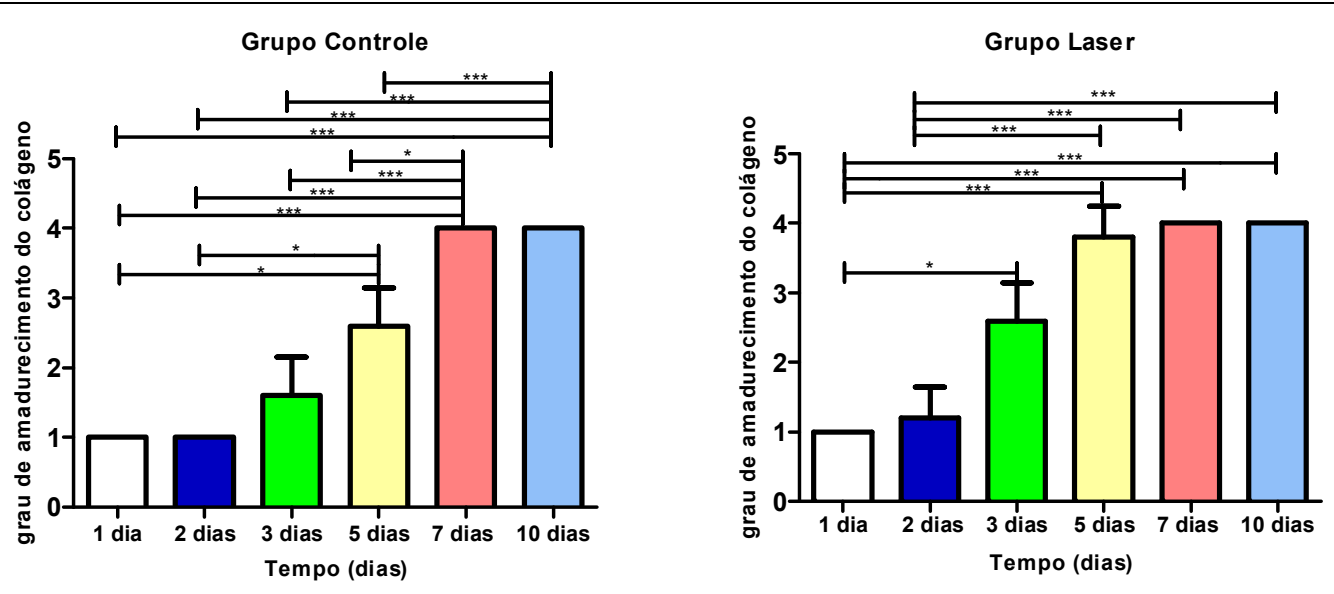

Figura 21: Expressão da média e desvio padrão no grau de amadurecimento do colágeno no Grupo Controle e Experimental. Os dados correspondem a 10 dias de experimento. ${ }^{*} p<0,05$; ${ }^{* *} p<0,01$; ${ }^{* * *} p<0,001 ; p>0,05=$ não significativo.

Quadro 7: Teste de Mann-Whitney para o evento grau de amadurecimento de colágeno.

\begin{tabular}{|c|c|c|}
\hline \multicolumn{3}{|c|}{ Comparação dois a dois } \\
\hline Periodos & & \\
\hline 1 dia (ns) & $\begin{array}{l}\text { Mann-Whitney (U) } \\
\text { Valor de } p\end{array}$ & $\begin{array}{l}7,5 \\
0,1797\end{array}$ \\
\hline 2 dias (ns) & $\begin{array}{l}\text { Mann-Whitney (U) } \\
\text { Valor de } p\end{array}$ & $\begin{array}{l}7,5 \\
0,1797\end{array}$ \\
\hline 3 dias $(n s)$ & $\begin{array}{l}\text { Mann-Whitney (U) } \\
\text { Valor de } p\end{array}$ & $\begin{array}{l}1,5 \\
0.0765 \\
\end{array}$ \\
\hline 5 dias $\left(^{*}\right)$ & $\begin{array}{l}\text { Mann-Whitney (U) } \\
\text { Valor de } p\end{array}$ & $\begin{array}{l}1,5 \\
0,0189 \\
\end{array}$ \\
\hline $7 \operatorname{dias}\left({ }^{\star * *}\right)$ & $\begin{array}{l}\text { Mann-Whitney (U) } \\
\text { Valor de } p\end{array}$ & $\begin{array}{l}12,5 \\
0,0001\end{array}$ \\
\hline 10 dias (ns) & $\begin{array}{l}\text { Mann-Whitney (U) } \\
\text { Valor de } p\end{array}$ & $\begin{array}{l}10 \\
0,4237 \\
\end{array}$ \\
\hline
\end{tabular}

* Nível de significância de $5 \%(p<0,05)$ 


\section{Imunomarcação para TRAP e RUNX-2}

A técnica imunoistoquímica empregada para a detecção de RUNX-2 e TRAP mostrou alta especificidade na detecção de tais proteínas, a qual foi comprovada pela ausência total de marcação no controle negativo da reação imunoistoquímica. As imunomarcações se apresentaram com uma coloração acastanhada confinadas ao compartimento nuclear, no caso de RUNX-2, ou citosólico, no caso de TRAP). A imunomarcação para RUNX-2 em pré-osteoblastos e a imunomarcação para TRAP foi expressa em osteoclastos. O número médio de perfis de células imunomarcadas estão representadas nas figuras a seguir.

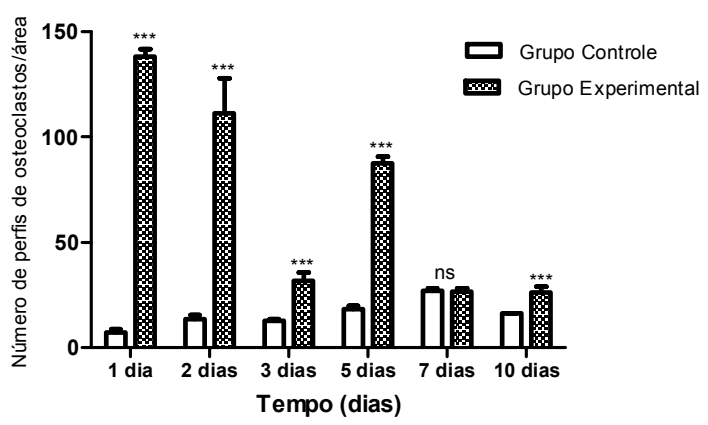

Figura 22 : Expressão da média e desvio padrão no número de perfis de células imunomarcadas para o TRAP no Grupo Controle e Experimental. Os dados correspondem a 10 dias de experimento. ${ }^{*} p<0,05 ;{ }^{* *} p<0,01 ;{ }^{* * *} p<0,001 ; p>0,05=$ não significativo.

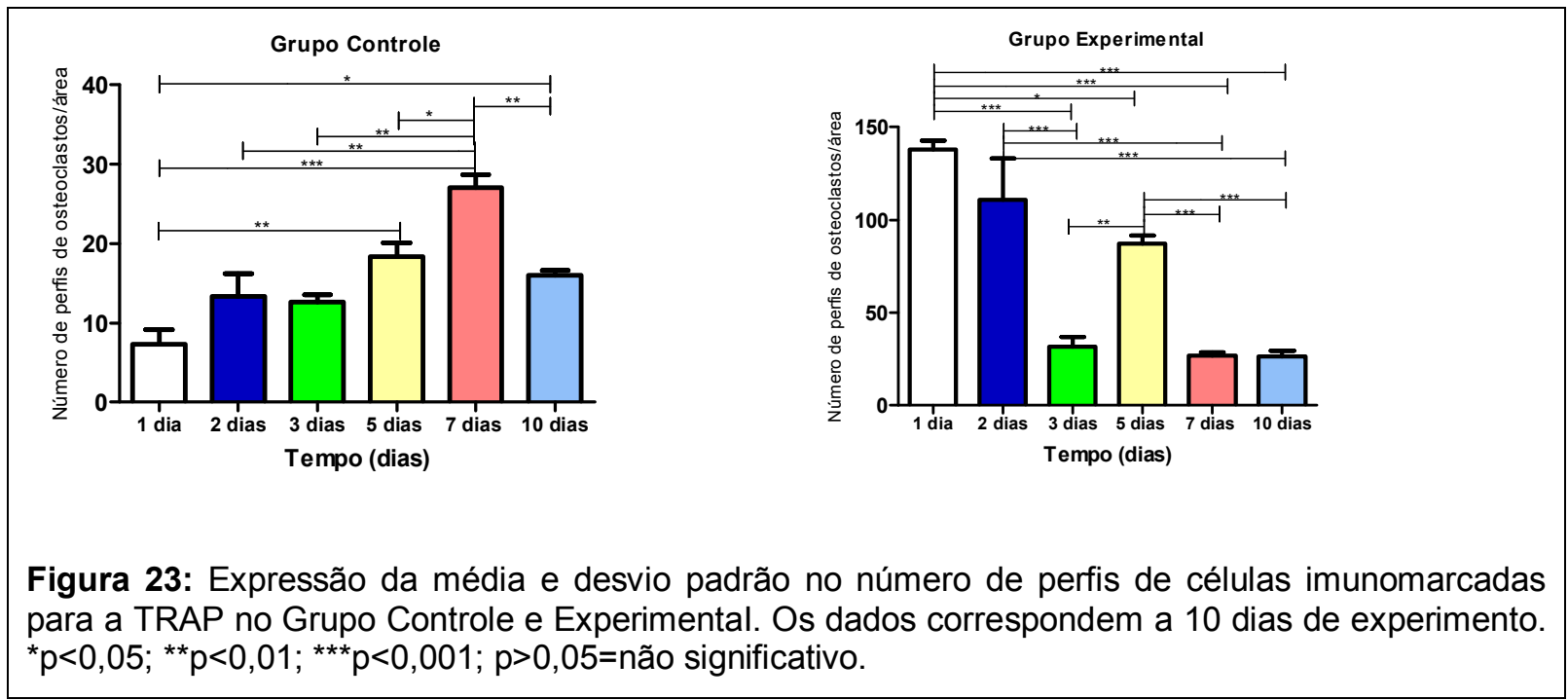




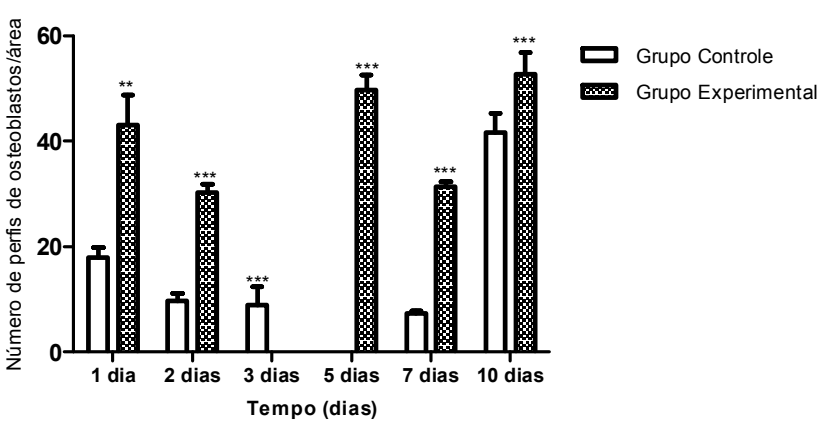

Figura 24: Expressão da média e desvio padrão no número de perfis de células imunomarcadas para o RUNX-2 no Grupo Controle e Experimental. Os dados correspondem a 10 dias de experimento. ${ }^{*} p<0,05 ;{ }^{* *} p<0,01 ;{ }^{* * *} p<0,001 ; p>0,05=$ não significativo.
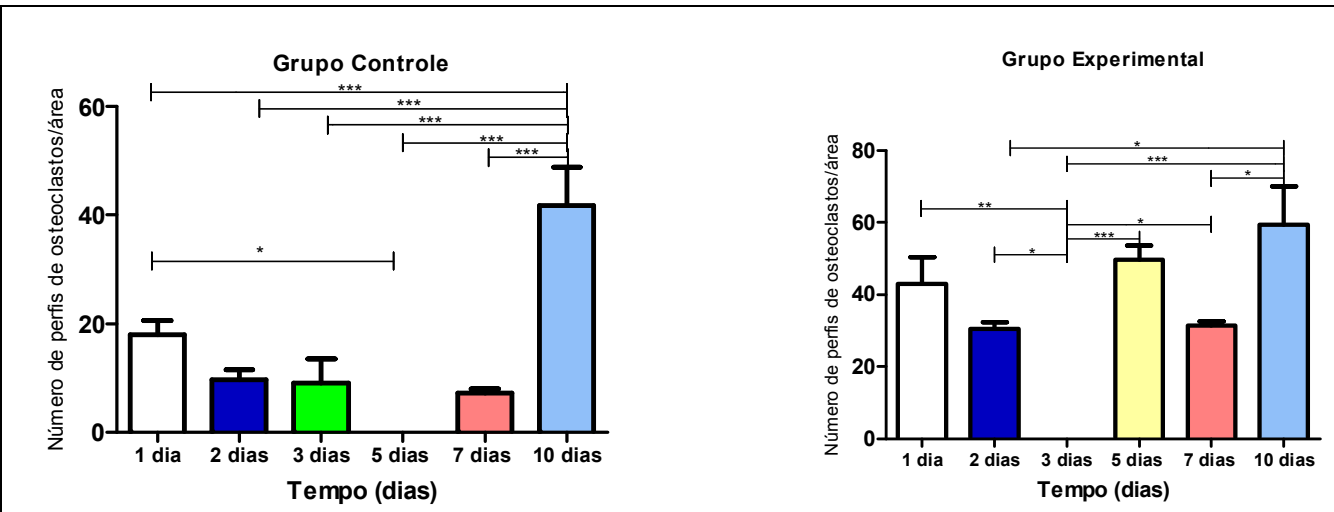

Figura 25: Expressão da média e desvio padrão no número de perfis de células imunomarcadas para o RUNX-2 no Grupo Controle e Experimental. Os dados correspondem a 10 dias de experimento. ${ }^{*} p<0,05 ;{ }^{* *} p<0,01 ;{ }^{* *} p<0,001 ; p>0,05=$ não significativo. 
A expressão das células imunomarcadas para a TRAP foi significativamente maior $(p<0,001)$ no Grupo Experimental do que no Grupo Controle em todos os períodos observados, principalmente nos dois primeiros dias, mostrando um novo pico aos 5 dias (Figura 22). A análise intra-grupo mostrou o mesmo comportamento, sendo que no Grupo Controle o novo pico foi aos 7 dias e no Grupo Experimental foi aos 5 dias (Figura 23).

$\mathrm{Na}$ análise inter-grupo a expressão das células imunomarcadas para o RUNX2 também foi significativamente maior $(p<0,001)$ no Grupo Experimental do que no Grupo Controle, em todos os períodos observados, com exceção de 3 dias, onde não foi observada imunomarcação, apresentando novo pico dos 5 aos 10 dias (Figura 24). A análise intra-grupo mostrou o mesmo comportamento, sendo que no Grupo Controle o novo pico foi aos 10 dias, no Grupo Experimental foi dos 5 aos 10 dias (Figura 25). 
5. Oiscussãa 


\section{DISCUSSÃO}

A utilização de animais para experimentação científica é etapa fundamental dentro do processo da pesquisa. O processo de reparo ósseo alveolar tem sido estudado em diversos tipos de modelos animais, sendo os ratos os mais utilizados. Essa escolha se justifica de modo prático e consensual por serem oriundos de uma mesma matriz, facilmente disponíveis, de fácil manipulação, manutenção e alimentação, produzidos de forma razoavelmente barata e existência de uma metodologia definida para reproduzir o reparo ósseo, vantagens também relatadas por outros autores (Zanetta-Barbosa et al., 1990; Jardini et al., 2005; Lustosa-Pereira et al., 2006; Mori et al., 2007; Poi et al., 2007; Gulinelli et al., 2008; Negri et al., 2008). A escolha do rato, como modelo animal experimental da remodelação óssea também pode ser explicado pelo fato das respostas dos tecidos ósseos destes mamíferos às injúrias serem semelhantes às encontradas em humanos (Klausen, 1991). Segundo estes autores, o rato é favorável como modelo experimental para o estudo da regeração óssea alveolar pela semelhança do seu periodonto com o do homem, tendo como divergência apenas a presença da queratinização do epitélio sulcular.

O modelo experimental utilizado também se justifica pela impossibilidade em alternativas humanas, conforme conceitos de bioética de pesquisa em animal e 
humanos. Neste experimento foram utilizados apenas ratos machos, para se evitar interferências de fatores como climatério e idade, nascidos em cativeiro laboratorial, com condições ideais de alojamento e alimentação, preenchendo as necessidades básicas para a realização do experimento. O projeto foi previamente submetido à aprovação pelo comitê de Ética e Uso de Experimento Animal da FORP-USP, podendo ser considerado uma pesquisa biologicamente aceitável.

O reparo de defeitos ósseos em alvéolos dentários é um bom modelo para estudo da regeneração óssea, pois qualquer lesão óssea ativa a regeneração local pela liberação de fatores e indutores de crescimento (Schenk, 1996) e tal procedimento experimental é relativamente fácil de realizar. O processo de remodelação óssea depende das fases de revascularização, incorporação, substituição e remodelação para o restabelecimento da arquitetura do osso hospedeiro (Anderson et al., 1964). O estudo do processo de reparo alveolar tem sido, ao longo dos anos, objeto de estudo de vários pesquisadores (Carvalho e Okamoto 1987; Oliveira, 2002; Lopes Júnior et al., 2001; Colli et al., 2012; Yamamoto-Silva et al., 2013), pois tem fornecido contribuições para o melhor entendimento da biologia óssea, uma vez que envolve eventos em que o organismo visa produzir osso com o intuito de preencher o alvéolo dental. Outra vantagem que observamos com a utilização desta metodologia foi que o alvéolo em reparo forneceu uma fonte de células mesenquimais que se diferenciaram e originaram as principais células responsáveis pela evolução do processo de reparo alveolar.

A maioria dos trabalhos relacionados à remodelação óssea utilizou métodos histológicos e histomorfométricos em lâminas histológicas para avaliar o processo de reparo ósseo. O presente trabalho demonstrou que a análise imunoistoquímica pode ser considerada uma importante ferramenta de estudo nesta área, eficaz por 
fornecer uma avaliação diferenciada da expressão e da localização de cada proteína envolvida no processo de reparo ósseo, fornecendo, portanto, informações complementares às obtidas na análise histomorfométrica. Além disso, este trabalho confirmou os relatos de Ducy et al., 1997; Wee et al., 2002; Camilleri e McDonald, 2006, quanto à participação das proteínas pesquisadas nesta pesquisa no processo de remodelação óssea.

O termo imunoistoquímica compreende o processo de identificação de antígenos em secções de tecidos com o auxílio de anticorpos específicos. Essa identificação se torna visível por meio de moléculas conjugadas aos anticorpos. O anticorpo liga-se ao antígeno específico, que por sua vez liga-se a um anticorpo secundário ao qual se liga ao complexo streptavidina-biotina-peroxidase. A peroxidase transforma em uma substância cromogênica, em geral a diaminobenzidina, que confere à reação positiva uma coloração acastanhada. 0 anticorpo utilizado nesta pesquisa foi o policlonal. Os anticorpos policlonais são gerados a partir de vários clones, ou seja, originam-se de diferentes línfócitos $B$, o que significa que reagem com vários epítopos do antígeno, ou seja, reconhecem mais de um epítopo em um mesmo antígeno. Já os monoclonais reagem apenas com um determinado epítopo presente em um antígeno. Para realizar as reações imunoistoquímicas, as lâminas foram submetidas à imunoperoxidase indireta empregando-se anticorpos primários contra a proteína TRAP e RUNX-2. Para todos os grupos foram realizados controles imunoistoquímicos. Para isto a lâmina passa por todo o processamento convencional, mas somente o anticorpo secundário é adicionado. O objetivo é avaliar a efetividade e especificidade das reações de TRAP e RUNX-2. Assim, funciona como uma contra-prova: se houver marcação no controle, provavelmente a imunomarcação das outras proteínas são inespecíficas. 
Não havendo marcação no controle, as marcações das demais proteínas são consideradas específicas, situação observada no presente trabalho, o que nos leva a confiar nos resultados da imunoistoquímica.

A pesquisa desenvolvida foi proposta com a finalidade de avaliar qualitativamente e quantitativamente a remodelação óssea alveolar e compreender melhor as questões pertinentes à ação do laser de baixa potência neste processo, uma vez que há carência de estudos relacionados na literatura pesquisada. Foram utilizados como Grupo Controle, alvéolos dentários submetidos à exodontia, preenchido com coágulo sanguíneo. Estudos até então realizados mostram que o melhor material a preencher o alvéolo dental pós exodontia e que permite as melhores respostas durante o processo de reparo alveolar consiste no coágulo sanguíneo (Carvalho e Okamoto, 1987; Okamoto et al., 1994). A pesquisa desenvolvida avaliou os efeitos da radiação laser de baixa potência nos tecidos periodontais após exodontia e aplicação do laser de baixa potência. Na literatura consultada, poucos trabalhos foram encontrados utilizando a laserterapia na reparação óssea de alvéolos. Por isso, despertou-nos o interesse em avaliar se a laserterapia pode auxiliar na manutenção da qualidade e quantidade do tecido ósseo após este procedimento cirúrgico.

De acordo com Eghballi-Fatourechi et al., 2003 as células envolvidas na remodelação óssea são os osteoclastos e osteoblastos, sendo que o equilíbrio entre ativação e apoptose destas células tem papel fundamental no processo de osteoclastogênse e na regulação da remodelação óssea. A descoberta e caracterização do sistema RANK-RANKL e OPG têm mudado os conceitos relativos ao metabolismo ósseo, levando a um melhor entendimento da patogênese das doenças ósseas metabólicas e alavancando novas estratégias terapêuticas 
(Menezes et al., 2006; Andrade et al., 2008). Outras proteínas como a TRAP e RUNX-2 também estão diretamente relacionadas à remodelação óssea, mas não há na literatura muitos trabalhos em relação à presença da TRAP e RUNX-2 em remodelação óssea após a laserterapia.

Em relação às respostas imunoistoquímicas, com o objetivo de melhor caracterizar a remodelação óssea, foram avaliadas as imunomarcações para a TRAP, proteína presente em osteoclastos ativos, identificando assim o processo de reabsorção óssea em andamento e o RUNX-2 identificando assim o processo de formação. Assim, foram avaliadas as respostas de sinalização celular quanto ao processo de remodelação óssea, ou seja, a relação entre formação e reabsorção óssea a partir da avaliação da imunomarcação para TRAP e RUNX-2. Também foi avaliada a maturação do colágeno através da luz polarizada (Picrus Sirus) que caracteriza a etapa de mineralização óssea, principalmente quando se avalia a sua presença na trabécula óssea neoformada, também permitindo que se avaliasse o grau de maturação do tecido ao longo da cronologia do processo de reparo alveolar.

A estratégia investigada neste trabalho foi avaliar o efeito bioestimulador do laser em baixa intensidade na remodelação óssea alveolar, que pode ser obtido utilizando-se diferentes equipamentos. O primeiro laser estudado com este efeito foi o laser de rubi $(694 \mathrm{~nm})$, em seguida vieram os de He-Ne (hélio e neônio, 632,8 nm), AsGa (gálio e arsenieto, 904nm), AsGaAl (gálio, alumínio e arsenieto, 780 a 890nm) e o InGaAIP (fosfato de índio gálio e alumínio, 630 a 700nm). O laser utilizado neste trabalho foi AsGaAl que tem como propriedades: potencial de penetração profunda, é portátil, de fácil utilização e de baixo custo.

$\mathrm{Na}$ literatura encontra-se diferentes protocolos de aplicação do laser de baixa 
potência nos estudos in vivo com relação ao comprimento de onda utilizado (Lopes et al., 2000; da Silva et al., 2006; Miloro et al., 2007), dosimetria (Freitas et al., 2000) tipo de lesão produzida (Carvalho et al., 2002; Khadra et al., 2005) e tecido estudado (Lopes et al., 2001; Shibli et al., 2006), o que dificulta uma comparação entre eles e também com o presente trabalho, o que levou muitos profissionais a desacreditarem nessa terapia. Sabe-se que o comprimento de onda, a energia total irradiada, a freqüência de emissão e a dose, estão diretamente relacionados com uma resposta celular eficiente à laserterapia, assim como as propriedades óticas dos tecidos (Takeda, 1988; Nicolau, 2001; Dortbudak et al., 2002). Portanto, com a diversidade de estudos existentes na literatura (Takeda, 1988; Oliveira, 2002) sobre o uso da irradiação laser no reparo ósseo não se tem ainda uma padronização quanto ao tipo de laser utilizado, considerando a utilização de diferentes meios ativadores, com comprimentos de onda também variados, além de outras variáveis como dosimetria, tempo de exposição empregado e o número de aplicações. A determinação dos parâmetros do laser utilizada nessa pesquisa baseou-se inicialmente em características inerentes ao equipamento escolhido no que diz respeito ao meio ativo, comprimento de onda, polarização, diâmetro, área e divergência do feixe de laser. O comprimento de onda, por sua vez, baseou-se no tecido alvo, ou seja, o interior do alvéolo dental. Desta forma, a luz infravermelha $(830 \mathrm{~nm})$ por ser mais penetrante, podendo atingir os tecidos profundos, foi utilizada no alvéolo, recomendações também feitas por outros autores quando se deseja maior penetração nos tecidos (Kana e Hutschenreiter, 1981; Brugnera Júnior et al., 1991; Saito e Shimizu, 1997; Genovese, 2000; Kawasaki e Shimizu, 2000). Porém, a enorme variação quanto aos parâmetros utilizados na laserterapia em processos de cicatrização, bem como a diversidade de modelos utilizados, têm dificultado uma 
interpretação adequada dos efeitos da irradiação, isso porque a escolha dos parâmetros do laser é efetuada de acordo com a experiência dos autores, uma vez que ainda não existem parâmetros universalmente aceitos. Muitos autores que usam protocolos de unidade de laser similares têm relatado resultados conflitantes. A partir dos relatos da literatura (Limeira-Junior, 2001) e dos resultados de nosso grupo de pesquisa, acreditamos que não há um determinado parâmetro que por si só produza os efeitos bioestimulatórios da laserterapia, mas a conjugação de parâmetros diferentes e suas variações de acordo com o modelo experimental adotado.

Apesar dos diversos trabalhos que destacam os benefícios da terapia laser, estudos sugerem que tais efeitos possam ser manifestados não só no local da irradiação como também a nível sistêmico. Acredita-se que este efeito se deva a mediadores metabólicos liberados na circulação, atingindo áreas distantes do local de aplicação (Kitchen e Partridge, 1991; Tuner e Hode, 1991; Laakso et al., 1993). Por esta razão optou-se por usar animais diferentes no Grupo Controle, ao invés de utilizar o alvéolo contra-lateral do mesmo animal, eliminando dessaforma os possíveis efeitos sistêmicos dessa terapia.

Apesar de vários estudos destacarem o sucesso dessa terapia no tratamento de fraturas (Luger et al., 1998; Freitas et al., 2000; Silva Júnior et al., 2002; Garavello-Freitas et al., 2003), foram utilizados parâmetros e tempo de tratamento muito diferente nesse trabalhos, o que dificulta a comparação com os mesmos. Além de parâmetros como de tempo e dosagem de tratamento, é relevante considerar que a quantidade e a qualidade do reparo ósseo, sob condições experimentais em modelo animal, são influenciadas pela espécie animal, idade, localização anatômica, envolvimento cortical (uni ou bicortical), presença ou ausência de periósteo e estabilidade do defeito ósseo (Aoboe et al., 1995). 
Ainda em relação ao protocolo de irradiação as feridas podem ser irradiadas de modo pontual ou em varredura, podendo ser utilizado uma única aplicação ou várias aplicações durante o pós-operatório. O protocolo de aplicação do laser em um único ponto foi escolhido devido ao fato de que o topo do alvéolo era do diâmetro da ponteira do aparelho do laser, sendo que a mesma envolvia todo o diâmetro superior do alvéolo, tornando mais fácil e precisa a padronização, além disso, teve-se o cuidado de colocar a ponteira da fibra óptica em contato direto com o tecido gengival do alvéolo. Porém alguns autores (Weber et al., 2006) preferem fazer a aplicação em varredura com doses menores para atingir os efeitos estimuladores sobre as células. No presente estudo foram realizadas aplicações diárias com o laser diodo por 3 dias consecutivos, o que corrobora com o protocolo utilizado por Takeda, 1988 entretanto, o protocolo de aplicação utilizado em outros trabalhos (Garcia, 1992; Garcia et al., 1995b; Garcia et al., 1996; Lizarelli e Lamano, 1999) foi de aplicação única do laser, como o que adotamos aqui, e os resultados obtidos nestas pesquisas foram semelhantes aos nossos.

Verificou-se neste estudo que o valor de densidade de $54 \mathrm{~J} / \mathrm{cm} 2$ foi adequado e eficaz na biorregulação ou normalização das funções celulares, contribuindo positivamente na regeneração do tecido ósseo após a exodontia. Aventamos, ainda, a hipótese de que a irradiação laser, no alvéolo dental estimulou a atividade mitocondrial e, consequentemente, com aumento da produção de ATP, havendo repercussão no aumento da atividade osteoblástica e fibroblástica, fato verificado nos cortes histológicos durante os períodos iniciais da presente pesquisa.

O laser em baixa intensidade utilizado neste estudo tem sido relacionado com um aumento na proliferação de células e estimulam fibroblastos, colaborando na produção de fibras colágenas mais ordenadas, determinando um melhor padrão de 
cicatrização nas lesões (Basford, 1986; Takeda, 1988; Ribeiro, 2000). Os resultados com a coloração com Picrus Sirus mostrou uma melhor organização do colágeno no grupo irradiado do que no controle, principalmente a partir de 5 dias. Esta modalidade terapêutica pode também, proporcionar efeitos antiinflamatórios, analgésicos e bioestimulantes, aumentando a microcirculação da área irradiada, promovendo melhores condições para o reparo tecidual (Mester e Jaszsagi-Nagy, 1973). Outros trabalhos usando um modelo experimental semelhante demonstraram que o laser teria efeitos estimulantes sobre a síntese de fibras colágenas, fibras elásticas e na proliferação de miofibroblastos, (Kana et al., 1981, Reenstra et al., 2001; Pugliese et al., 2003; Houreld e Abrahamse, 2007) além de reduzir a resposta inflamatória (Medrado et al., 2003; Mendez et al., 2004) fazendo com que feridas tratadas por essa luz apresentassem uma contração e epitelização mais rápida (Surinchak et al., 1983; Al-Watban e Zhang, 1997). Quando analisamos a influência do laser no número de células inflamatórias houve uma redução mais acentuada e significativa do número destas células no grupo irradiado com a passar dos dias, demonstrando uma tendência ao reparo mais acelerado do tecido conjuntivo neste grupo em relação ao controle (Figura 18). No período inicial de 24 horas o alvéolo estava totalmente preenchido por coágulo sanguíneo, com restos do ligamento periodontal rico em fibroblastos e vasos sanguíneos em ambos os grupos. Com dois e três dias, as feridas do Grupo Experimental mostraram rápida organização e reabsorção do coágulo sanguíneo, assim como proliferação de fibroblastos e vasos sanguíneos mais evidentes que no controle. A reação inflamatória no período inicial é um processo natural do organismo. Após o trauma e a injúria dos vasos sanguíneos locais, forma-se um coágulo rico em fibrina, sendo que neste estudo, com 2 dias foi observada uma reação inflamatória aguda, formação de tecido de 
granulação com novos capilares, macrófagos e fibroblastos. Somado a esse efeito o laser também promove uma maior regulação da enzima ciclo-oxigenase (Thaller, 1991) que converte o ácido aracdônico em prostanóides, modulando a resposta inflamatória (Matsumoto et al., 2008), e isto conseguimos detectar no presente trabalho, onde observou-se uma redução do processo inflamatório maior no grupo irradiado do que no controle e em contrapartida houve um estímulo dos fibroblastos, colaborando na formação precoce das fibras colágenas mais ordenadas em relação ao Grupo Controle, observadas na coloração de Picrus Sirus, determinando um melhor padrão de cicatrização e formação óssea.

A intensa proliferação vascular e fibroblástica observada principalmente no Grupo Experimental nos períodos de 3 à 7 dias, deve-se provavelmente à ação do laser nas células remanescentes das fibras do ligamento periodontal que permaneceram aderidas à parede alveolar, o que concorda com resultados obtidos por outros autores (Garcia, 1992; Garcia et al., 1995b; Garcia et al., 1996; NicolliFilho e Okamoto, 1994; Takeda, 1988). Este fato provavelmente foi responsável pela aceleração no processo de reparo do grupo irradiado, onde a evolução do reparo foi mais evidente e rápida, caracterizado por organização mais rápida do coágulo sanguíneo, proliferação vascular intensa e mais precoce, além de fechamento epitelial mais rápido do alvéolo. Estes fenômenos tornaram-se mais intensos no período de 5 dias, quando o alvéolo irradiado apresentou-se totalmente preenchido com tecido conjuntivo neoformado, o que fortalece as evidências de que a ação do laser se processa a nível vascular e celular, com maior intensidade nas fases iniciais do processo de reparo. Estes achados histológicos observados na coloração de H/E foram confirmados na coloração de TM e PS.

Apesar do maior número de estudos realizados com a terapia laser de baixa 
potência estar direcionado na avaliação do reparo de feridas cutâneas (Oliveira et al., 1997), esta terapia também exerce uma ação estimulatória sobre as células osteogênicas aumentando o número de células osteoprogenitoras e formação óssea no início do processo de reparo (Barushka et al., 1995; Ozawa et al., 1995; Ueda e Shimizu, 2001) o que está de acordo com nossos resultados. Nos tecidos duros, a irradiação com laser de baixa potência tem mostrado um aumento na vascularização e do número de trabéculas ósseas em danos na tíbia de ratos com aceleração na organização da matriz colágena e no processo de reparo (Trelles e Mayayo, 1987; Barushka et al., 1995; Yaakobi et al., 1996; Garavello-Freitas et al., 2000; GaravelloFreitas et al., 2003). No presente trabalho, nos períodos iniciais (até 3 dias) de observação não foi obeservado neo-formação óssea. Nestes estágios predominou o coágulo sanguíneo, presença de células inflamatórias e início da organização das fibras colágenas. A formação óssea foi avaliada nos períodos finais (após 5 dias) do experimento. Aos 5 dias, o Grupo Controle demonstrou um atraso no processo de reparo, apresentando ainda áreas de coágulo sanguíneo, associado com uma discreta quantidade de fibroblastos migrados da região da borda do alvéolo, poucos vasos sanguíneos e ainda células inflamatórias. Isto pode estar relacionado com o tamanho do defeito em relação ao tempo de reparo. No Grupo Experimental, houve uma melhora do processo de reparo comparado ao Controle, sendo que o grupo com laser apresentou um tecido conjuntivo mais desenvolvido com maior quantidade de fibroblastos, vasos sanguineos, macrófagos e linfócitos. A literatura (Yaakobi et al.,1996) mostrou que os efeitos bioenergéticos, bioelétricos e bioestimuladores levam a um aumento na produção de ATP que facilita o processo de reparo celular. Em adição, esses efeitos levam a normalização do potencial iônico da membrana celular, revitalizando as funções celulares e promovendo a síntese de ATP sintetase 
para a produção de ácido nucléico e aceleração na divisão celular e sua ativação da microcirculação proporciona elevados níveis de oxigenação e nutrição para os tecidos, melhorando consideravelmente, o metabolismo e regeneração tecidual (Pretel et al., 2007). O Grupo Experimental apresentou maior maturação no processo de reparo tecidual em relação ao Grupo Controle mostrando maior quantidade de fibroblastos, vasos sanguineos e atividade osteogênica em algumas espécies.

O processo de reparo alveolar constitui-se numa sequência de eventos que envolvem respostas dinâmicas com o único objetivo de formar tecido ósseo preenchendo a cavidade óssea formada após a exodontia, mantendo a homeostasia mineral do organismo (Carvalho e Okamoto, 1987). Em modelo experimental de rato, este processo encontra-se completo aos 28 dias, com o alvéolo preenchido completamente por tecido ósseo, a crista alveolar remodelada e o epitélio da mucosa gengival totalmente regenerado (Okamoto e Fialho, 1990). Outros autores (Takeda, 1988; Garcia, 1992; Garcia et al., 1995b; Garcia et al., 1996, LimeiraJunior, 2001) verificaram em ratos, que a reparação óssea alveolar total ocorre aproximadamente aos 21 dias pós-operatório. Porém, os tempos de análise utilizados na presente pesquisa foram no máximo de 10 dias, pois o nosso interesse estava focado nos estágios iniciais da remodelação óssea, uma vez que trabalhos anteriores de nosso grupo de pesquisa mostraram que o laser não produziu efeito nos estágios posteriores da ossificação e, isso foi novamente confirmado aqui onde aos 10 dias de avaliação não foi verificado diferença significativa na formação óssea entre o Grupo Controle e experimental (GC 77,13\% $\pm 2,08 \%$ versus GE $82,77 \% \pm$ 2,43\%). Porém nos períodos de 5 e 7 dias a análise histométrica indicou que a neoformação óssea na área do alvéolo, foi significativamente maior nos grupos experimentais do que no Grupo Controle, sendo que nestes períodos os grupos 
experimentais apresentaram melhor resultado que o Grupo Controle, (GC 13,29\% \pm $0,83 \%$ versus GE $26,17 \% \pm 0,70 \%$ aos 5 dias e GC $21,48 \% \pm 1,41 \%$ versus GE $30,74 \% \pm 1,36 \%$ aos 7 dias). Esses dados podem também ser observados através da análise histológica, na qual, o Grupo Experimental apresentou significante quantidade de matriz óssea e trabeculado ósseo em formação com numerosos osteócitos, além de grande quantidade de osteoblastos nas bordas do tecido ósseo neoformado, tecido conjuntivo vascularizado e rico em fibras colágenas, precocemente em relação ao Grupo Controle. Somado a isso, a literatura (Khadra, Kasem, Haanaes, Ellingsen e Lyngstadaas, 2004) mostrou que a influência do laser em baixa intensidade pode estimular a deposição de cálcio, fosfato e proteínas insolúveis no tecido em cicatrização. Além disso, animais tratados com laser em baixa intensidade demonstraram nos períodos iniciais do processo de reparo uma grande produção de RUNX-2, confirmando a intensa atividade de pré-osteoblastos e deposição de matrix óssea o que vai de encontro com outros autores (Nissan et al., 2006). O atraso no tempo dos eventos de reparação no Grupo Controle pode estar relacionado com a falta da atividade osteoblástica nos períodos iniciais, a qual leva a uma menor formação óssea fato relatado na literatura (Fang et al., 1991; Fung et al., 1999; Pinto et al., 2002). No presente experimento observou-se uma maior expressão de RUNX-2 após 10 dias de experimento, o que também pode ser relacionado com os resultados de Picrus Sirus que demonstrou um atraso na reparação do colágeno em relação ao Grupo Experimental. Estes resultados também foram confirmados com o quadro histológico. A partir do $5^{\circ}$ dia pósextração, começou a ser evidenciado tecido conjuntivo neoformado com inclusão de alguns espécimes ósseos, sendo aumentado progressivamente do terço apical ao cervical nos períodos subseqüentes e mais intenso no Grupo Experimental. Com 7 
dias, mostrou-se a formação de finas trabéculas ósseas, sendo que, no Grupo Experimental pôde ser evidenciada em toda a extensão do alvéolo, enquanto que no controle foi observado apenas nos terços médio e apical, uma vez que o terço cervical apresentou tecido conjuntivo sem diferenciação óssea. Ao $10^{\circ}$ dia, no Grupo Controle pôde ser observado tecido ósseo neoformado em toda a extensão do alvéolo, com características distintas nos terços médio e apical onde foram caracterizadas trabéculas ósseas mais espessas e bem definidas quando comparadas ao terço cervical; no Grupo Experimental o alvéolo encontrava-se totalmente preenchido por tecido ósseo neoformado, sendo as trabéculas ósseas do terço cervical mais delgadas e menos delimitadas que nas demais regiões. Também nos animais do Grupo Controle foi possível observar que as trabéculas ósseas neoformadas apresentavam um discreto atraso na maturação quando comparadas às formadas no grupo laser.

A análise histométrica deste trabalho em relação à formação óssea final (10 dias) revelou que, apesar de não apresentar diferença estatística pode-se observar que houve nos grupos tratados com laser, maior formação óssea quando comparados aos grupos controle (Figura 16; Quadro 3). Portanto, a irradiação com laser em baixa intensidade estimulou a atividade das células osteogênicas e resultou em proliferação celular e diferenciação, aumentando a formação óssea, porém parece que essa ação estimulatória do laser sobre as células osteogênicas presentes na região do alvéolo dental é mais evidente nos estágios iniciais do processo de reparo, não ocorrendo em períodos mais tardios (10 dias) concordando com outros autores (da Silva e Camilli, 2006).

No período de 10 dias, a maioria das espécies do Grupo Controle e experimental apresentava sinais de incorporação do osso neoformado, revelada por 
pontes ósseas ligando a face interna da parede alveolar ao osso neoformado. $\mathrm{O}$ processo de incorporação, primeiramente, resulta da reabsorção osteoclástica periférica e infiltração vascular dos canais de Volkmann e Havers (Enneking et al., 1975). O Grupo Experimental mostrou maior maturidade no processo de reparo ósseo em relação ao Controle nos períodos de 5 e 7 dias devido aos efeitos do laser em baixa intensidade, pois segundo a literatura (Dominguez et al., 2009) os osteoblastos são sensíveis ao laser em baixa intensidade, favorecendo a formação e remodelalmento ósseo. Os resultados histométricos confirmam esses achados (GC $13,29 \% \pm 0,83 \%$ versus GE $26,17 \% \pm 0,70 \%$ aos 5 dias e GC $21,48 \% \pm 1,41 \%$ versus GE $30,74 \% \pm 1,36 \%$ aos 7 dias; GC $77,13 \% \pm 2,08 \%$ versus GE $82,77 \% \pm$ 2,43\% aos 10 dias, apesar deste último período não ter sido significante. Os autores consideram o período de 21 dias para o reparo total dos alvéolos de ratos e no presente experimento com metade desse tempo (10 dias) tivemos praticamente $80 \%$ dos alvéolos preenchido com tecido ósseo. Extrapolando os resultados para situações clínicas, poderíamos considerar que pacientes com fraturas ósseas ou extrações dentárias precisariam de períodos mais longos no pós-operatório para uma completa incorporação da remodelação do alvéolo dentário. Contudo, a utilização do laser em baixa intensidade proporcionaria melhores condições de reparo para esses pacientes nos períodos iniciais da remodelação óssea. Porém, outros estudos ainda são necessários para esclarecer a ação isolada do laser sobre o reparo ósseo em situações normais e adversas, como também sua associação com substâncias fotossensibilizadoras durante os estágios do processo de reparo ósseos.

Portanto, a radiação laser aplicada no alvéolo em reparação favoreceu os processos de neoformação e reabsorção óssea, superando os resultados dos 
aspectos histológicos dos animais dos grupos controle. Os resultados demonstraram que a terapia laser de baixa potência promove estimulação da remodelação óssea não alterando a microarquitetura óssea o que vai de encontro com a literatura (Takeda, 1988; Garcia et al., 1996; Lamano e Lizarelli, 1999; Nicolau, 2001; Guzzardella et al., 2002; Oliveira, 2002; Silva Júnior et al., 2002) que avaliando o processo de reparo alveolar de ratos também verificaram que a quantidade de osso formado foi maior no grupo irradiado. Comprovando a efetiva ação bioestimuladora da radiação laser nos tecidos periodontais durante o processo de reparo alveolar. Verificamos, também, que os ratos submetidos à radiação laser apresentavam maior número de células imunorreativas para RUNX-2 quando comparados com os ratos do Grupo Controle, Ressalva-se, também, que o aumento do número de préosteoblastos imunorreativos para RUNX-2 apresentou significância estatística, principalmente, entre os grupos Controle e Experimental, em todos os períodos de observação. $\mathrm{Na}$ análise imunoistoquímica, as imunomarcações contra RUNX-2 mostraram a presença de pré-osteoblastos no tecido conjuntivo ao redor das trabéculas ósseas delgadas e também nos osteócitos aprisionados no interior das trabéculas ósseas. A literatura (Kanatani, et al. 2006) mostrou que o RUNX-2 é um fator de transcrição essencial para a diferenciação de osteoblastos. No Grupo Controle, as imunomarcações positivas para a RUNX-2 seguiram o padrão esperado, com uma discreta marcação nos períodos iniciais e uma maior marcação após 10 dias (Figura 24 e 25), porém, nos Grupo Experimental as imunomarcações positivas para a RUNX-2 estavam presentes em todos os períodos revelando uma maturação precoce do tecido neste grupo.

Verificamos, também, que os ratos submetidos à radiação laser apresentavam maior número de osteoclastos imunorreativos para a TRAP quando 
comparados com os ratos do Grupo Controle. A TRAP caracteriza a reabsorção óssea marcando osteoclastos em atividade. Considerando que o processo de reparo alveolar envolve predominantemente a resposta de formação de tecido ósseo, inicialmente havia a idéia de que a TRAP estaria pouco presente, principalmente nas etapas iniciais. Entretanto, desde o primeiro dia pós exodontia, foram observados vários osteoclastos com marcação positiva para TRAP presentes nas bordas do alvéolo dental. No Grupo Controle houve um aumento gradativo no número de células imunomarcadas para TRAP tanto ao redor do alvéolo dental, como também junto às trabéculas ósseas neoformadas, apresentando um pico aos 7 dias. No Grupo Experimental, este pico foi no início do experimento com diminuição nas marcações de osteoclastos positivos para TRAP após 7 dias. Este resultado mostrou que mesmo num processo que se caracteriza principalmente pela deposição óssea, ou seja, o predomínio da formação óssea há necessidade de disponibilização de cálcio e fosfato com o objetivo de garantir a homeostasia mineral; por este motivo consideramos que a imunomarcação expressiva para TRAP pode ter um papel muito importante neste sentido.

Em nossos resultados, demonstramos que as atividades osteoblásticas e osteoclásticas no interior do alvéolo dentário, foram concomitantes, promovendo formação e reabsorção óssea durante os períodos experimentais. No Grupo Experimental constatamos, ainda, que houve significância estatística no aumento do número de osteoblastos imunorreativos para RUNX-2 em todos os períodos e diminuição gradativa no aumento do número de osteoclastos imunorreativos para TRAP. Com isso, verificamos que a quantidade de osteoclastos imunorreativos era inversamente proporcional a quantidade de osteoblastos imunorreativos, confirmando a dinâmica fisiopatológica do processo de remodelação óssea alveolar, 
pois o binômio neoformação óssea/reabsorção é controlado pela relação osteoblasto/osteoclasto. Realizando uma análise geral das proteínas TRAP e RUNX2 pode-se observar que, de uma forma global, o turnover ósseo foi mais lento nos grupos controles em virtude de que, apesar das altas concentrações dessas proteínas ressalta-se que há nestes grupos altos níveis de RUNX-2 com consequente menor expressão da TRAP. Estes fatos demonstraram a evolução do processo de remodelação óssea até o período de 10 dias experimentais, outra hipótese seria a inibição do metabolismo celular devido à produção excessiva de de ATP no interior da mitocôndria, induzida pela irradiação laser. De acordo com Miloro et al., 2007 e Costardi et al., 2008, esta radiação intensifica a formação de um gradiente de fóton eletroquímico transmembrana na mitocôndria, promove liberação de cálcio da mitocôndria no citoplasma e, consequentemente, estimula a mitose e a proliferação celular. Todavia, altas ou frequentes doses aumentam excessivamente a liberação de cálcio, causando hiperatividade das bombas de cálcio ATPase e estabilização do "pool" de ATP da célula, inibindo o metabolismo celular.

$\mathrm{Na}$ análise intergrupo, o tratamento com laser apresentou um número maior de células TRAP positivas nos animais dos grupos dos tempos iniciais comparado aos animais do Grupo Controle. Isto confirma uma aceleração no processo de reparo nesses grupos determinada pela sua ação na proliferação celular, demonstrando também, que os resultados do uso do laser foram menos efetivos nos animais dos grupos tardios. Dessa forma, a atuação do laser na proliferação celular dos osteoblastos, fibroblastos, macrófagos, linfócitos, auxiliando ainda na diferenciação e ativação dos osteoclastos e pré-osteoblastos observada na presente pesquisa, justifica uma resposta acelerada no reparo ósseo nos grupos irradiados em comparação ao controle o que está de acordo com relatos de outros pesquisadores 
(Dube et al., 2003; Vladimirov et al., 2004; Correa et al., 2007; Houreld et al., 2007; Mirzaei et al., 2007; Chen et al., 2008; Pires Oliveira et al., 2008).

Considerando a metodologia empregada e os resultados obtidos neste estudo, a terapia com laser diodo favoreceu o processo de aceleração da cronologia dos eventos biológicos da regeneração óssea alveolar, tendo em vista a formação mais precoce de tecido de granulação cicatricial, fibras colágenas e de trabéculas ósseas. Porém, é necessário ressaltar que cada um dos parâmetros do laser utilizado, ou seja, o comprimento de onda, a potência de saída, modo de emissão, modo de aplicação, número de aplicações, área de aplicação, energia, tempo de exposição; densidade energética de radiação tem um papel importante no resultado obtido com o uso do LLLT (Vladimirov et al., 2004; Correa et al., 2007; Houreld e Abrahamse, 2007). Assim, a ação do laser (LLLT) para a área de ossificação alveolar ainda necessita de uma ampla investigação pela grande quantidade de variáveis que podem alterar a resposta obtida e o presente resultado deve ser interpretado como um dos parâmetros iniciais. Além disso, o metabolismo ósseo é regulado por uma gama de mediadores, muitos dos quais ainda haverão de ser descobertos e, portanto, há que se concordar com Asaba et al., 2009 no sentido de que mais estudos e pesquisas são necessários para melhor compreensão da dinâmica óssea e de determinar os protocolos de aplicação do laser mais eficientes para cicatrização óssea alveolar. 
6. Condusãa 


\section{CONCLUSÃO}

O presente trabalho, nas condições experimentais em que foi desenvolvido, permitiu as seguintes conclusões:

- Através da análise descritiva dos eventos histológicos, a ação do laser em baixa intensidade, nas especificações deste estudo, favoreceu o processo de remodelação óssea após a extração dentária em ratos. Nos tempos pós-operatórios de até sete dias, os resultados no reparo ósseo no grupo irradiado foram melhores do que no grupo não irradiado. No tempo pós-operatório final (10 dias) não houve diferença no reparo ósseo entre o grupo irradiado e o não irradiado.

- O número de perfis de células inflamatórias, grau de amadurecimento do colágeno e números de trabéculas ósseas formadas durante o experimento foram mais significativas e precoces no grupo irradiado do que no controle, principalmente nos períodos iniciais.

- O número de células imunorreativas para as proteínas TRAP e RUNX-2 foram mais significativas no grupo irradiado comparado com o controle $e$ inversamente proporcional. 
7. ORefexencias 


\section{REFERÊNCIAS}

1. Aaboe M, Pinholt EM, Hjørting-Hansen E. Healing of experimentally created defects: a review. Br J Oral Maxillofac Surg. 1995 Oct; 33(5):312-8.

2. Aaboe M. Incomplete bone regeneration of rabbit calvarial defects using different membranes. Clin Oral Implants Res. 1998. v. 9 n.5 p. 313-320.

3. Al-Watban FA, Zhang XY. Comparison of wound healing process using Argon and Krypton lasers. J Clin Laser Med Surg. 1997;15(5):209-15.

4. Amler $\mathrm{MH}$. The time sequence of tissue regeneration in human extraction wounds. Oral Surg Oral Med Oral Pathol 1969 Mar;27(3):309-18.

5. Anderson KJ, LeCocq JF, Akeson WH, Harrington PR. End-point results of processed heterogenous, autogenous and homogenous bone transplants in the human: a histologic study. Clin Orthop Relat Res. 1964 Mar-Apr;33:220-36.

6. Andrade FR, Sousa DP, Mendonça EF, Silva TA, Lara VS, Batista AC. Expression of bone resorption regulators (RANK, RANKL, and OPG) in odontogenic tumors. Oral Surg Oral Med Oral Pathol Oral Radiol Endod. 2008;106(4):548-55.

7. $\quad$ Asaba Y, Ito M, Fumoto T, Watanabe K, Fukuhara R, Takeshita S, Nimura Y, Ishida J, Fukamizu A, Ikeda K. Activation of renin-angiotensin system induces osteoporosis independently of hypertension. J Bone Miner Res. 2009 Feb;24(2):241-50.

8. Aubin JE. Advances in the osteoblast lineage. Biochem Cell Biol. 1998; 76 (6): 899-910.

9. Barushka O, Yaakobi T, Oron U. Effect of low-energy laser ( $\mathrm{He}-\mathrm{Ne})$ irradiation on the process of bone repair in the rat tibia. Bone. 1995 Jan;16(1):47-55.

10. Basford JR. Low-energy laser treatment of pain and wounds: hype, hope, or hokum? Mayo Clin Proc. 1986 Aug;61(8):671-5.

11. Basford JR. Low-energy laser treatment of pain and wounds: hype, hope, or hokum? Mayo Clin Proc. 1986 Aug;61(8):671-5

12. Brugnera JA, Zanin F. Tratamento da hipersensibilidade dentinária. In: Lasers na Odontologia Moderna, Brugnera J.A. Pinheiro ALB.-São Paulo: Pancast. 1998, cap.19, p.297-306.

13. Brugnera Júnior A, Villa RG, Genovese WJ. Laser na Odontologia. 1. ed. São Paulo: Pancast, 1991.

14. Calixto RFE. Implante de um Foliculado de Resina Derivado do Óleo de Mamona 
(Ricinus comunnis) em Alveolo de Rato Imediatamente após a Extração Dental. Avaliações Histológicas e Histométricas da Biocompatibilidade e da Cronologia do Reparo Ósseo. 2001. 72 p. Dissertação (Mestrado em Odontologia-Área).

15. Camilleri S, McDonald F. Runx2 and dental development. Eur J Oral Sci 2006; 114: 361373.

16. Carvalho ACP, Okamoto T. Cirurgia bucal: fundamentos experimentais aplicados a clínica. São Paulo: Panamericana; 1987.

17. Carvalho PSP, Luppino F, Mendes VC. Histofisiologia óssea e os biomateriais aplicados à implantodontia. In: BEZERRA FJB, LENHARO A. Terapia clínica avançada em implantodontia. São Paulo, Artes Médicas, 2002.

18. Cattaneo V, Cetta G, Rota C, Vezzoni F, Rota MT, Gallanti A, Boratto R, Poggi P. Volatile components of cigarette smoke: effect of acrolein and acetaldehyde on human gingival fibroblasts in vitro. J Periodontol. 2000 Mar;71(3):425-32.

19. César-Neto JB, Benatti BB, Sallum EA, Casati MZ \& Nociti JR FH. The influence of cigarette smoke inhalation and its cessation on the tooth-supporting alveolar bone: a histometric study in rats. J Periodontal Res 41, 2006; 118-123.

20. Chen $\mathrm{CH}$, Hung HS, Hsu SH. Low-energy laser irradiation increases endothelial cell proliferation, migration, and e nos gene expression possibly via PI3K signal pathway. Lasers Surg Med. 2008 Jan;40(1):46-54.

21. Chomette G, Auriol M, Zeitoun R, Mousques T. [Effect of the soft laser on gingival connective tissue. I--Effect on fibroblasts. Histoenzymology and electron microscopy study]. J Biol Buccale 1987 Mar; 15(1):45-9.

22. Chomette G, Auriol M, Zeitoun R, Mousques T. [Effect of the soft laser on gingival connective tissue. Il--Effect on wound healing. Optical microscopy, histoenzymology and electron microscopy studies]. J Biol Buccale 1987 Mar;15(1):51-7.

23. Colli VC, Okamoto R, Spritzer PM, Dornelles RC. Oxytocin promotes bone formation during the alveolar healing process in old acyclic female rats. Arch Oral Biol. 2012 Sep;57(9):1290-7.

24. Colls J. La terapia laser actual. Barcelona: Centro de Documentación Laser-Medtec, 1984.

25. Correa F, Lopes Martins RA, Correa JC, Iversen VV, Joenson J, Bjordal JM. Low-level laser therapy (GaAs lambda $=904 \mathrm{~nm})$ reduces inflammatory cell migration in mice with lipopolysaccharide-induced peritonitis. Photomed Laser Surg. 2007 Aug;25(4):245-9.

26. Costardi CHZ, Tamachiro C, Junior IE, Gomes AC. Efeito do laser de baixa intensidade $(670 \mathrm{~nm})$ após contusão muscular em ratos. Fisioter Mov. 2008;21(2):21-30.

27. Da Silva RV, Camilli JA. Repair of bone defects treated with autogenous bone graft and low-power laser. J Craniofac Surg. 2006 Mar; 17(2):297-301.

28. Dahlin C, Sennerby L, Lekholm U, Linde A, Nyman S. Generation of new bone around titanium implants using a membrane technique: an experimental study in rabbits. Int J Oral Maxillofac Implants. 1989 v.4 p.19-25.

29. Dominguez A, Castro $P$, Morales M. An In Vitro study of the reaction of human osteoblasts to low-level laser irradiation. J Oral Laser Applic 2009;9:21-28.

30. Dortbudak O, Haas R, Mallath-Pokorny G. Biostimulation of bone marrow cells with a diode soft laser. Clin Oral Implants Res 2000 Dec; 11 (6): 540-5. 
31 implant sites. Clin. Oral Impl. Res. 2002; I 3, p. 288-292.

32. Dube A, Bansal H, Gupta PK. Modulation of macrophage structure and function by low level He-Ne laser irradiation. Photochem Photobiol Sci. 2003 Aug;2(8):851-5.

33. Ducy $P$, Schinke $T$, Karsenty $G$, The osteoblast: a sophisticated fibroblast under central surveillance. Science 2000 Sep 1; 289(5484): 1501-4.

34. Ducy P, Zhang R, Geoffroy V, Ridall AL, Karsenty G. Osf2/Cbfa1: a transcriptional activator of osteoblast differentiation. Cell 1997 May 30; 89(5): 747-54.

35. Eghballi-Fatourechi G, Klosla S, Sanyal A, Boyle WJ, Lacey DL, Riggs BL. Role of RANK ligand in mediating increased bone resorption in early pos menopausal women. J Clin Invest 2003; 111:1221-1230.

36. Enneking WF, Burchardt $\mathrm{H}$, Puhl JJ, Piotrowski G. Physical and biological aspects of repair in dog cortical-bone transplants. J Bone Joint Surg Am. 1975 Mar;57(2):237-52.

37. Euler H. Die Heilung von extraktions wounden. Detsch. Manat. Ank. 1923; v. 41, pp. 685689.

38. Fang MA, Frost PJ, lida-Klein A, Hahn TJ. Effects of nicotine on cellular function in UMR 106-01 osteoblast-like cells. Bone. 1991;12(4):283-6.

39. Felix R, Hofstetter W, Wetterwald A, Cecchini MG, Fleisch H. Role of colony-stimulating factor-1 in bone metabolism. J Cell Biochem 1994 Jul; 55(3): 340-9.

40. Freitas AC, Pinheiro AL, Miranda P, Thiers FA, Vieira AL. Assessment of antiinflammatory effect of 830nm laser light using C-reactive protein levels. Braz Dent J 2001;12(3):18790.

41. Freitas LGF, Baranauskas V \& Cruz-Höfling MA. Laser effects on osteogenesis. Appl Surface Sci 2000; 154-158, 548-554.

42. Fukushima O, Bekker PJ, Gay CV. Ultrastructural localization of tartrate-resistant acid phosphatase (purple acid phosphatase) activity in chicken cartilage and bone. Am J Anat $1991 \mathrm{Jul}$; 191(3): 228-36.

43. Fung YK, Iwaniec U, Cullen DM, Akhter MP, Haven MC, Timmins P. Long-term effects of nicotine on bone and calciotropic hormones in adult female rats. Pharmacol Toxicol. 1999 Oct;85(4):181-7.

44. Garant PR. Oral Cells and Tissues. Illinois: Quintessence Books; 2003.

45. Garavello-Freitas I, Baranauskas V, Cruz-Höfling MA. Laser effects on osteogenesis. Appl.Surf.Sci. 2000; P.548-554.

46. Garavello-Freitas I, Baranauskas V, Joazeiro PP, Padovani CR, Dal Pai-Silva M, da CruzHöfling MA. Low-power laser irradiation improves histomorphometrical parameters and bone matrix organization during tibia wound healing in rats. J Photochem Photobiol B. 2003 May-Jun;70(2):81-9.

47. Garavello-Freitas I, et al. Low-power laser irradiation improves histomorphometrical parameters and bone matrix organization during tibia wound healing in rats. Journal of Photochemistry and Photobiology B: Biology. 2003; V. 70, p. 81-89.

48. Garcia VG, Carvalho PS, Oliveira JA. Ação da radiação laser na reparação de feridas de extração dental infectadas: Estudo Histológico em Ratos. Rev. RGO.1995b; v. 4, n. 43, p. 191-194. 
extração dental submetidas ao tratamento com raio laser: estudo histológico em ratos. Rev. Fac. Odont. Lins, 1996; vol.9-n¹, pags.32-42 jan/jun.

50. Garcia VG, Theodoro LH, Colman LS, Fonseca RG, Okamoto T. Influência do número de aplicações de raio laser de bioestimulação sobre a reparação de feridas de extração dentária. Estudo Histológico em Ratos. Rer. Facud. Odontol. Lins. Jan/Abr. 2000; v. 12, nº 1, p. 29-37.

51. Garcia VG. Comportamento de feridas cutâneas submetidas à ação do Raio Laser. Estudo clinico, biométrico e histológico em ratos. 1992. Tese/Livre-Docência. Faculdade de Odontologia, UNESP, Araçatuba-SP.

52. Genovese WJ. Laser de baixa intensidade: aplicações terapêuticas em odontologia. 1. ed. São Paulo: Lovise, 2000.

53. Gulinelli JL, Panzarini SR, Fattah CM, Poi WR, Sonoda CK, Negri MR, Saito CT. Effect of root surface treatment with propolis and fluoride in delayed tooth replantation in rats. Dent Traumatol. 2008 Dec;24(6):651-7.

54. Gulinelli JL, Panzarini SR, Fattah CM, Poi WR, Sonoda CK, Negri MR, Saito CT. Effect of root surface treatment with propolis and fluoride in delayed tooth replantation in rats. Dent Traumatol. 2008 Dec;24(6):651-7.

55. Guzzardella GA, et al. Stimulation on Bone Defect Healing: An In Vitro Study. Lasers Med. Sci. 2002; v. 17, p. 216-220.

56

Hall BK. Bone. Boca Raton: FL: CRC Press; 1994.

57. Hedner E, Linde A. Efficacy of bone morphogenetic protein (BMP) with osteopromotive membranes - an experimental study in rat mandibular defects. Eur. J. Oral Sci., Copenhagen. Aug. 1995 ; v. 103 , n. 4 , p. $236-241$.

58. Hofbauer LC, Khosla S, Dunstan CR, Lacey DL, Boyle WJ, Riggs BL. The roles of osteoprotegerin and osteoprotegerin ligand in the paracrine regulation of bone resorption. $\mathrm{J}$ Bone Miner Res 2000 Jan; 15(1): 2-12.

59. Holland R, Mazuqueli L, Souza V, Murata SS, Dezan Júnior E, Suzuki P. Influence of the type of vehicle and limit of obturation on apical and periapical tissue response in dogs teeth after root canal filling with mineral trioxide aggregate. J Endod 2007; 33:693-7.

60. Houreld $\mathrm{N} \&$ Abrahamse $\mathrm{H}$. In vitro exposure of wounded diabetic fibroblast cells to a helium-neon laser at 5 and $16 \mathrm{~J} / \mathrm{cm} 2$. Photomed Laser Surg. 2007 Apr;25(2):78-84.

61. Houreld NN, Abrahamse $\mathrm{H}$. Effectiveness of helium-neon laser irradiation on viability and cytotoxicity of diabetic-wounded fibroblast cells. Photomed Laser Surg. 2007 Dec;25(6):474-81.

62. Jardini MA, De Marco AC, Lima LA. Early healing pattern of autogenous bone grafts with and without e-PTFE membranes: A histomorphometric study in rats. Oral Surgery, Oral Medicine, Oral Pathology, Oral Radiology and Endodontics 2005; 100: 666-73.

63. Jardini MAN, de Marco AC \& Lima LA. Early healing pattern of autogenous bone grafts with and without e-PTFE membranes: A histomorphometric study in rats. Oral Surgery, Oral Medicine, Oral Pathology, 2005. Oral Radiology and Endodontics 100: 666-73.

64. Junqueira LC, Carneiro J. Tecido Ósseo. Histologia Básica. 9 ed. Rio de Janeiro: Guanabara Koogan; 1999. P.111-28.

65. Kana J S e Hutschenreiter G. Effect of low-power laser radiation on healing of open skin wounds in rats. Arch.Surg: 1981; v. 116, p. 293-296.

66.

Kana JS, Hutschenreiter G, Haina D, Waidelich W. Effect of low-power density laser 
radiation on healing of open skin wounds in rats. Arch. Surg., Chicago. Mar.1981; v. 116, n. 3, p. 293296.

67. Kanatani N, Fujita T, Fukuyama R, Liu W, Yoshida CA, Moriishi T, Yamana K, Miyazaki T, Toyosawa S, Komori T. Cbf beta regulates Runx2 function isoform-dependently in postnatal bone development. Dev Biol. 2006 Aug 1;296(1):48-61.

68. Katchburian E, Arana V. Tecido Ósseo. Histologia e Embriologia Oral. Texto - Atlas Correlações Clínicas. Rio de Janeiro: Guanabara Koogan; 1999. p. 21-38.

69. Kawasaki K, Shimizu N. Effects of low-energy laser irradiation on bone remodeling during experimental tooth movement in rats. Lasers Surg Med 2000; 26(3):282-91.

70. Khadra M, Kasem N, Haanaes HR, Ellingsen JE, Lyngstadaas SP. Enhancement of bone formation in rat calvarial bone defects using low-level laser therapy. Oral Surg Oral Med Oral Pathol Oral Radiol Endod 2004 Jun; 97(6): 693-700.

71. Khadra M, Ronold HJ, Lyngstadaas SP, Ellingsen JE, Haanaes HR. Low-level laser therapy stimulates bone-implant interaction: an experimental study in rabbits. Clin Oral Implants Res 2004 Jun;15(3):325-32.

72. n.3, p.161-168.

Kitchen SS, Partridge CJ. A review of low level laser therapy. Physiotherapy, 1991; v. 77,

73. Klausen B. Microbiological and immunological aspects of experimental periodontal disease in rats: a review article. $J$ Periodontol 62, 1991; 59-73.

74. Laakso L, Richardson C, Cramond T. Quality of light - is laser necessary for effective photobiostimulation? Australian J. 1993; Physiotherapy, v.39, n. 2, p. 87-92.

75. Lerner UH. Osteoclast formation and resorption. Matrix Biol 2000 May; 19(2): 107-20.

76. Lian JB, Stein GS. Concepts of osteoblast growth and differentiation: basis for modulations of bone cell development and tissue formation. Crit Rev Oral Biol Med 1992; 3 (3): 269305.

77. Limeira Júnior FA. Avaliação do processo de reparo ósseo com o uso de osso anorgânico e membrana reabsorvível após irradiação com laser diodo 830nm. 2001. Dissertação (Mestrado em Odontologia). Faculdade de Odontologia da Universidade Federal da Bahia. SalvadorBahia.

78. Liu X, Lyon R, Meier HT, Thometz J, Haworth ST. Effect of lower-level laser therapy on rabbit tibial fracture. Photomed Laser Surg 2007 Dec; 25(6):487-94.

79. Lizarelli RFZ, Lamano CTL. Histometrical evaluation of the healing of the dental alveolus in rats after irradiation with a low-powered GaAlAs laser. Laser Dent. 1999; N. 3543, p. 49-56.

80. Lopes Junior W, Garcia VG, Okamoto T, Theodoro LH, Eduardo CP. Repairing process in infected wounds dental extraction, treated with protosensitizer drug, associated or no the low intensity laser: histological study in mice. Journal Of Oral Laser Applications 2001;1:49-49.

81. Lopes Júnior, W. Reparação em feridas de extração dental, infectadas, tratadas com droga fotossensibilizadora associada ou não ao laser de baixa intensidade. 2000. 142f. Dissertação (Mestrado em Periodontia) - Faculdade de Odontologia, Universidade Estadual Paulista, Araçatuba.

82. Luger EJ, Rochkind S, Wollman Y, Kogan G, Dekel S.. Effect of low-power laser irradiation on mechanical properties of bone fracture healing rats. Lasers Surgery Medicine, 1998; v. 22, n.2, p.97-102. 
EA. Evaluation of the topical effect of alendronate on the root surface of extracted and replanted teeth. Microscopic analysis on rats' teeth. Dent Traumatol. 2006 Feb;22(1):30-5

84.

Maiman TH. Stimulated optical radiation in ruby. Nature. 1960; v. 187, pp. 493-494.

85. Markel MD, Wikenheiser MA, Chao EY. Formation of bone in tibial defects in a canine model. Histomorphometric and biomechanical studies. J. Bone Joint Surg. Am., Boston. July 1991; v. 73, n. 6, p. 914-923.

86. Matsumoto MA, Ferino RV, Monteleone GF, Ribeiro DA. Low-level laser therapy modulates cyclo-oxygenase-2 expression during bone repair in rats. Lasers Med Sci. 2009 Mar;24(2):195-201. doi: 10.1007/s10103-008-0544-4. Epub 2008 Feb 29.

87. Medrado AR, Pugliese LS, Reis SR, Andrade ZA. Influence of low level laser therapy on wound healing and its biological action upon myofibroblasts Lasers Surg Med. 2003; 32(3):239-44.

88. Mendez TM, Pinheiro AL, Pacheco MT, Nascimento PM, Ramalho LM. Dose and wavelenght of laser light have influence on the repair of cutaneous wounds. J Clin Laser Med Surg. 2004 Feb;22(1):19-25.

89. Menezes R, Bramant CM, da Silva Paiva KB, Letra A, Carneiro E, Fernando Zambuzzi $\mathrm{W}$, et al. Receptor activador NF-KappaB-ligand and osteoprotegerin protein expression in human periapical cysts and granulomas. Oral Surg Oral Med Oral Pathol Oral Radiol Endod. 2006;102(3):404-9.

90. Mester E, Nagylucskay S, Tisza S, Mester A. Stimulation of wound healing by means of laser rays. Part III--Investigation of the effect on immune competent cells. Acta Chir Acad Sci Hung 1978;19(2):163-70.

91. Mester S, Jaszsagi-Nagy E. The effect of laser radiation on wound healing and collagen biosynthesis. Stud Biophys 1973;35:227-230.

92. Miller SC, Jee WS. Bone lining cells. In: Hall B.K., editor. Bone. Boca Raton: FL: CRC Press; 1992. P. 1-20.

93. Miloro M, Miller JJ, Stoner JA. Low-level laser effect on mandibular distraction osteogenesis. J Oral Maxillofac Surg 2007 Feb; 65(2): 168-76.

94. Minkin C. Bone acid phosphatase: tartrate- resistant acid phosphatase as a marker of osteoclast function. Calcif Tissue Int 1982 May; 34(3): 285-90.

95. Mirzaei M, Bayat M, Mosafa N, Mohsenifar Z, Piryaei A, Farokhi B, Rezaei F, Sadeghi Y, Rakhshan M. Effect of low-level laser therapy on skin fibroblasts of streptozotocin-diabetic rats. Photomed Laser Surg. 2007 Dec;25(6):519-25.

96. Mori GG, Garcia RB, Gomes de Moraes I, Bramante CM, Bernardineli N. Morphometric and microscopic evaluation of the effect of a solution of alendronate as an intracanal therapeutic agent in rat teeth submitted to late reimplantation. Dent Traumatol 2007;23:218-21

97. Mori Y, Hinchcliff M, Wu M, Warner-Blankenship M, M Lyons K, Varga J. Connective tissue growth factor/CCN2-null mouse embryonic fibroblasts retain intact transforming growth factorbeta responsiveness. Exp Cell Res. 2008 Mar 10;314(5):1094-104.

98. Nakagawa N, Kinosaki M, Yamaguchi K, Shima N, Yasuda H, Yano K, Morinaga T, Higashio K. RANK is the essential signaling receptor for osteoclast differentiation factor in osteoclastogenesis. Biochem Biophys Res Commun 1998 Dec 18; 253(2): 395-400.

99. Nefussi JR, Sautier JM, Nicolas V, Forest N. How osteoblasts become osteocytes: a decreasing matrix forming process. J Biol Buccale 1991 Mar; 19(1): 75-82. 
100.

Negri MR, Panzarini SR, Poi WR, Sonoda CK, Gulinelli JL, Saito CT. Analysis of the healing process in delayed tooth replantation after root canal filling with calcium hydroxide, Sealapex and Endofill: a microscopic study in rats. Dent Traumatol. 2008 Dec;24(6):645-50.

101. Nicolau, R.A. Efeito do Laser de Baixa Potência (As-Ga-Al) em tecido ósseo de rato submetido à lesão, analisado por histomorfometria óssea. Universidade do Vale do Paraíba. 2001. 100 p. Dissertação (Mestrado EM Engenharia Biomédica) - Universidade do Vale do Paraíba - São José dos Campos, SP. Orientadores: Prof. Dr. Renato Amaro Zângaro (Univap); Profa ${ }^{a}$. Dra ${ }^{a}$. Vanda Jorgetti (USP).

102. Nicolli-Filho W, Okamoto T. Effect of the Helium Neon laser on the healing of extraction wounds a histological study in rats. J. Laser Application, 1994; v. 6, p. 237-240.

103. Nishihara T, Takahashi T, Ishihara Y, Senpuku H, Takahashi N, Suda T, Koga T. Membrane-associated interleukin-1 promotes osteoclast-like cell formation in vitro. Bone Miner 1994 Apr; 25(1): 15-24.

104. Nissan J, Assif D, Gross MD, Yaffe A, Binderman I. Effect of low intensity laser irradiation on surgically created bony defects in rats. J Oral Rehabil 2006 Aug; 33(8): 619-924.

105. Okamoto T, de Russo MC. Wound healing following tooth extraction. Histochemical study in rats. Rev Fac Odontol Aracatuba 1973;2(2):153-69.

106. Okamoto T, Fialho ACV. Estudo histologico comparativo entre dois métodos de obtencao de cortes de alveolos de ratos. Rev Odont UNESP 1990;19:63-74.

107. Oliveira JAGP et. al. Ação da irradiação laser (Arsênio-Gálio) sobre a cronologia do processo de reparo em feridas cutâneas. Estudo histológico em ratos. ROBRAC, 1997; v. 6(21), p. 28-31.

108. Oliveira JAGP. Ação da radiação laser (Arsênio-Gálio) no reparo alveolar de feridas de extração dental infectadas. Estudo histológico em ratos. 2002.78p. Tese (Doutorado em Odontologia) Faculdade de Odontologia de Araçatuba - UNESP, Araçatuba-SP.

109. Owens JM, Gallagher AC, Chambers TJ. IL-10 modulates formation of osteoclasts in murine hemopoietic cultures. J Immunol 1996 Jul 15; 157(2): 936-40.

110. Ozawa $Y$ et al. Stimulatory effects of low-power laser irradiation on bone formation in vitro. In: Altshuler GB, Blankenau RJ, Wigdor HÁ, editors. Advanced Laser Dentistry. Proc SPIE 1984:281-288; 1995.

111. Perkins SL, Kling SJ. Local concentrations of macrophage colony-stimulating factor mediate osteoclastic differentiation. Am J Physiol 1995 Dec; 269(6 Pt 1): E1024-E1030.

112. Pinheiro ALB. Evolução Histórica e Classificação dos Lasers. In: Brugnera Júnior A, Pinheiro ALB. Lasers na Odontologia Moderna, São Paulo: Pancast, 1998 p.19-26.

113. Pinto JR, Bosco AF, Okamoto T, Guerra JB, Piza IG. Effects of nicotine on the healing of extraction sockets in rats. A histological study. Braz Dent J. 2002;13(1):3-9.

114. Pires Oliveira DA, de Oliveira RF, Zangaro RA, Soares CP. Evaluation of low-level laser therapy of osteoblastic cells. Photomed Laser Surg. 2008 Aug;26(4):401-4.

115. Poi WR, Carvalho RM, Panzarini SR, Sonoda CK, Manfrin TM, Rodrigues Tda S. Influence of enamel matrix derivative (Emdogain) and sodium fluoride on the healing process in delayed tooth replantation: histologic and histometric analysis in rats. Dent Traumatol. 2007 Feb;23(1):35-41.

116. Pretel H, Lizarelli RF, Ramalho LT. Effect of low-level laser therapy on bone repair: histological study in rats. Lasers Surg Med. 2007 Dec;39(10):788-96. 
117. Pugliese LS, Medrado AP, Reis SR, Andrade ZDE. The influence of low-level laser therapy on biomodulation of collagen and elastic fibers. Pesqui. Odontol. Bras., São Paulo. 2003; v. 17, n. 4, p. 307- 313.

118. Quinn JM, McGee JO, Athanasou NA. Cellular ad hormonal factors influencing monocyte differentiation to osteoclastic bone-resorbing cells. Endocrinology 1994 Jun; 134(6):2416-23.

119. Quinn JM, Neale S, Fujikama Y, McGee JO, Athanasou NA. Human osteoclast formation from blood monocytes, peritoneal macrophages, and bone marrow cells. Calcif Tissue Int 1998 Jun; 62(6): 527-31.

120. Reenstra WR, Veves A, Orlow D et al. Decrease proliferation and cellular signaling in primary dermal fibroblasts derived from diabetics versus non diabetic sibling controls. Acad Emerg. Med 2001;8:519.

121. Ribeiro MS. Interação da radiação laser linearmente polarizada de baixa intensidade com tecidos vivos: Efeitos na aceleração de cicatrização tissular em lesões de pele. (Tese Doutorado) 2000, São Paulo: Instituto de Pesquisa Nuclear, IPEN/USP.

122. Robey PG, Fedarko NS, Hefferan TE, Bianco P, Vetter UK, Grzesik W, Friedenstein A, Van der Pluijm G, Mintz KP, Young MF, et al. Structure and molecular regulation of bone matrix proteins. J Bone Miner Res. 1993 Dec;8 Suppl 2:S483-7.

123. Robling $\mathrm{AG}$, Catillo $\mathrm{AB}$, Turner $\mathrm{CH}$. Biomechanical and molecular regulation of bone remodeling. Annu Rev Biomed Eng 2006; 8: 4555-98.

124. Saito S, Shimizu N. Stimulatory effects of low-power laser irradiation on bone regeneration in midpalatal suture during expansion in the rat. Am J Orthod Dentofacial Orthop 1997 May;111(5):52532.

125. Schenk RK. Regeneração óssea: bases biológicas. In: Buser D, Dahlin C, Schenk RK. Regeneração óssea guiada na implantodontia. São Paulo, Quintessence, 1996, p. 49-100.

126. Shibli JA, Martins MC, Ribeiro FS, Garcia VG, Nociti FH \& Marcantonio E. Lethal photosensitization and guided bone regeneration in treatment of peri-implantitis: an experimental study in dogs. 2006; Clin Oral Implants Res 17, 273-281.

127. Silcox DH 3rd, Boden SD, Schimandle JH, Johnson P, Whitesides TE, Hutton WC. Reversing the inhibitory effect of nicotine on spinal fusion using an osteoinductive protein extract. Spine, Philadelphia. Feb. 1998; v. 23, n. 3, p. 291-297.

128. Silva Júnior AN, Pinheiro AL, Oliveira MG, Weismann R, Ramalho LM, Nicolau RA. Computerized morphometric assessment of the effect of low-level laser therapy on bone repair: an experimental animal study. J. Clin. Laser Med. Surg., New York. Apr. 2002; v. 20, n. 2, p. 83-87.

129. Stein GS, Lian JB, Owen TA. Relationship of cell growth to the regulation of tissue-specific gene expression during osteoblast differentiation. FASEB J 1990 Oct; 4(13): 3111-23.

130. Stein GS, Lian JB, Stein JL, van Wijnen AJ, Montecino M. Transcriptional control of osteoblast growth and differentiation. Physiol Rev 1996 Apr; 76(2): 593-629.

131. Stuani, MBS. Remodelação óssea e expressão do gene $R U N X 2$, aos a expansão rápida da maxila, em ratos, com e sem aplicação do laser de baixa potência. Ribeirão Preto, 2011. Tese (livredocência)- Faculdade de Odontologia de Ribeirão Preto, Usp.

132. Suda T, Jimi R, Nakamura I, Takahashi N. Role of 1 alpha, 25-dihydroxyvitamin D3 in osteoclast differentiation and function. Methods Enzymol 1997; 282: 223-35.

133. Suda T, Udagawa N, Nakamura I, Miyaura C, Takahashi N. Modulation of osteoclast differentiation by local factors. Bone 1995 Aug; 17(2 Suppl): 87S-91S. 
134. Surinchak JS, Alago ML, Bellamy RF, Stuck BE, Belkin M. Effects of low-level energy lasers on the healing of full-thickness skin defects. Lasers Surg Med. 1983;2(3):267-74.

135. Takeda Y. Irradiation effect of low-energy laser on alveolar bone after tooth extraction. Experimental study in rats. Int J Oral Maxillofac Surg 1988 Dec;17(6):388-91.

136. Tao $\mathrm{H}$, Minkin $\mathrm{C}$. The effects of 1,25-dihydroxyvitamin D3 on osteoclast formation in fetal mouse metatarsal organ cultures. Bone 1994 Mar; 15(2): 217-23.

137. Teitelbaum SL, Abu-Amer Y, Ross FP. Molecular mechanisms of bone resorption. J Cell Biochem 1995 Sep; 59(1): 1-10.

138. Ten Cate AR. Histologia Básica, Desenvolvimento, Estrutura e Função. 5 ed. Rio de Janeiro: Guanabara Koogan: 2001.

139. Thaller S. Immediate bone grafting in craniofacial trauma. In: Manson, P. editor. Craniomaxillofacial trauma, Philadelphia: W.B. Saunders, 1991; p. 408-419.

140. Torricelli P, Giavaresi G, Fini M, Guzzardella GA, Morrone G, Carpi A, Giardino R. Laser biostimulation of cartilage: in vitro evaluation. Biomed Pharmacother 2001 Mar; 55(2): 117-20.

141. Trelles MA, Mayayo E. Bone fracture consolidates faster with low-power laser. Lasers Surg Med 1987; 7(1): 36-45.

142. Tuner J, Hode L. Low level laser therapy: clinical practice and scientific background. Sweden: Prima Books, 1999.

143. Ueda Y, Shimizu N. Effects of pulse frequency of low-level laser therapy (LLLT) on bone nodule formation in rat calvarial cells. J Clin Laser Med Surg 2003 Oct;21(5):271-7.

144. Ueda, Y; Shimizu, N. Pulse irradiation of low-power laser stimulates bone nodule formation. Hua Xi Kou Qiang Yi Xue Za Zhi. oct. 2001; v. 19, n. 5, p. 290-3.

145. Vladimirov YA, Osipov AN, Klebanov GI. Photobiological principles of therapeutic applications of laser radiation. Biochemistry (Mosc). 2004 Jan;69(1):81-90.

146. Weber JBB, Pinheiro ALB, Oliveira MG, Oliveira FAM, Ramalho LMP. Laser therapy improves healing of bone defects submitted to autologus bone graft. Photomedicine and Laser Surgery 2006;24:38-44.

147. Wee HJ, Huang G, Shigesada K, Ito Y. Serine phosphorylation os RUNX2 with novel potential functions as negative regulatory mechanisms. EMBO Rep 2002 Oct; 3(10): 967-74.

148. Wolfson EM, Seltzer S. Reaction of rat connective tissue to some guttapercha formulations. J Endod 1975; 1:395-402.

149. Yaakobi T, Maltz L, Oron U. Promotion of Bone Repair in the Cortical Bone of the Tibia in Rats by Low Energy Laser (He-Ne) Irradiation. Calcified Tissue International. 1996; v. 59, nº 4, p. 297-300.

150. Yamamoto-Silva FP, Bradaschia-Correa V, Lima LA, Arana-Chavez VE. Ultrastructural and immunohistochemical study of early repair of alveolar sockets after the extraction of molars from alendronate-treated rats. Microsc Res Tech. 2013 Jun;76(6):633-40.

151. Yasuda H, Shima N, Nakagawa N, Mochizuki SI, Yano K, Fujise N, Sato Y, Goto M, Yamaguchi K, Kuriyama M, Kanno T, Murakami A, Tsuda E, Morinaga T, Higashio K. Identity of osteoclastogenesis inhibitory factor (OCIF) and osteoprotegerin (OPG): a mechanism by which OPG/OCIF inhibits osteoclastogenesis in vitro. Endocrinology. 1998 Mar;139(3):1329-37.

152. Zanetta-Barbosa D, de Carvalho AC. Effect of brief storage in ATP solution on periodontal healing after replantation of teeth in rats. Endod Dent Traumatol. 1990 Oct;6(5):193-9. 